\title{
Components for PEM Fuel cells: An Overview
}

\author{
T. Maiyalagan, Sivakumar Pasupathi* \\ South African Institute for Advanced Materials Chemistry (SAIAMC), University of the \\ Western Cape, Modderdam Road, Bellville 7535, Cape Town, South Africa \\ Email: spasupathi@uwc.ac.za, Tel: +27-21-9599318, Fax: +27-21-9591583
}

\begin{abstract}
Fuel cells, as devices for direct conversion of the chemical energy of a fuel into electricity by electrochemical reactions, are among the key enabling technologies for the transition to a hydrogen-based economy. Among the various types of fuel cells, polymer electrolyte membrane fuel cells (PEMFCs) are considered to be at the forefront for commercialization for portable and transportation applications because of their high energy conversion efficiency and low pollutant emission. Cost and durability of PEMFCs are the two major challenges that need to be addressed to facilitate their commercialization. The properties of the membrane electrode assembly (MEA) have a direct impact on both cost and durability of a PEMFC.

An overview is presented on the key components of the PEMFC MEA.. The success of the MEA and thereby PEMFC technology is believed to depend largely on two key materials: the membrane and the electro-catalyst. These two key materials are directly linked to the major challenges faced in PEMFC, namely, the performance, and cost. Concerted efforts are conducted globally for the past couple of decades to address these challenges. This chapter aims to provide the reader an overview of the major research findings to date on the key components of a PEMFC MEA.
\end{abstract}

Keywords: PEMFC, proton exchange membrane, gas diffusion layers, electrocatalysts, membrane electrode assembly, CO tolerant catalysts, ORR 


\section{Introduction}

In response to the pressing global issues pertaining to sustainable energy generation and increasing pollution, a strong research drive globally is to develop environmentally clean and efficient alternatives to fossil fuels. The hydrogen economy, where hydrogen produced through renewable sources, is used as an energy carrier is believed by many as the ideal future energy scenario. The conversion of hydrogen to energy can be achieved through many means including combustion but the most efficient method will be to use a fuel cell, where the chemical energy of hydrogen is directly converted into electrical energy. Among the various types of fuel cells, the proton exchange membrane fuel cells (PEMFCs) are currently leading the commercial front for its advantages such as low temperature operation, quick startup time and dynamic operation capabilities. Significant advancements in fundamental, engineering and technological aspects have been achieved for PEMFCs, leading to a wide range of portable, automotive and stationary applications. PEMFCs operate at low temperature (below $100^{\circ} \mathrm{C}$ ) and generate a specific power $\left(\mathrm{W} \mathrm{kg}^{-1}\right)$ and power density $(\mathrm{g} / \mathrm{W})$ higher than any other type of fuel cell.

The drive for zero emission vehicles has led to great technological strides in the development of PEMFC. Several demonstrations in cars, buses as well as highly publicized investment by leading car manufacturers have given the technology a high media profile. Most of the world's largest automotive manufacturers including GM, Daimler Chrysler, Ford, Toyota, Nissan, Hyundai and Honda have also recognized the importance of early fuel cell commercialization and are also involved in the development of stationary fuel cells as a means of building their overall capacity in automotive fuel cell applications for the longer term. Large established manufacturers, such as DuPont, Gore, SGL, 3M and Johnson Matthey, are positioning themselves to become world suppliers of PEMFC components.

The commercialization of PEMFCs is hampered by two key aspects, longevity or durability of some key components like membranes and electrodes and also the high cost of fuel cell systems. The durability of a PEM fuel cell relies mainly on the characteristics of the membrane electrode assembly (MEA), while the reduction in cost critically depends on enhancing the performance of the MEAs while minimizing the Pt content. The lowering of the platinum loading on the electrodes has become the subject of much research [2-4]. Platinum comprises a large portion of the PEMFC's cost due to its high price and limited supply. The catalyst accounts for $55 \%$ of the total stack cost (not including the balance of plant), while $7 \%$ belongs to membrane, $10 \%$ to bipolar plates, and $10 \%$ to gas diffusion layers [5]. Developing high-performance, cost-effective and durable electrocatalysts is the number one priority for PEMFC research and development.

The cost targets of the US Department of Energy (DOE) for PEM fuel cell stack is 30 \$ per $\mathrm{kW}$ by 2015 which is way down from the current value of $110 \$$ per $\mathrm{kW}$ [6]. Most of this reduction has to be from the Pt catalyst, bipolar plate and PEM although total elimination of Pt for oxygen reduction reaction (ORR) has been recently indicated as a tangible possibility 
$[7,8]$. Cost effectiveness can be obtained by using alternative materials, i.e. less noble metal catalysts, cheaper materials for the electrodes, cheaper and thinner membranes, and also by reducing the need for peripheral equipment, such as a gas humidification section and compressors. The latter aspects will also reduce the weight of the system. Of course, the advantages of cheaper materials and simpler systems must not outweigh the disadvantages of any reduction of the power density. A better understanding of components and operating conditions in PEM fuel cell is essential to the development and optimization of fuel cells, leading to the introduction of cheaper materials, better fabrication techniques, improved design and development of novel architectures. In order to address the above challenges, extensive studies are being carried out the results are being published, with a huge increase in the number of articles on catalysts, membranes, MEAs etc. This chapter is aimed to provide an overview of the R\&D on PEMFC MEA components, highlighting the developments in this area.

\section{Components of PEMFC}

A basic schematic of a PEMFC is provided in Fig. 1. Hydrogen gas is fed to the fuel cell anode, which travels through the gas diffusion layer (GDL) to the anodic catalytic layer where it is oxidized, resulting in proton transfer through the proton exchange membrane (PEM) and electron transfer through an external electrical circuit. At the same time, oxygen gas is fed to the cathode and upon diffusion to the cathodic catalytic layer, it combines with the protons and is reduced to water. The anodic and cathodic reactions as well as the overall cell reaction are shown in Equation 1-2.

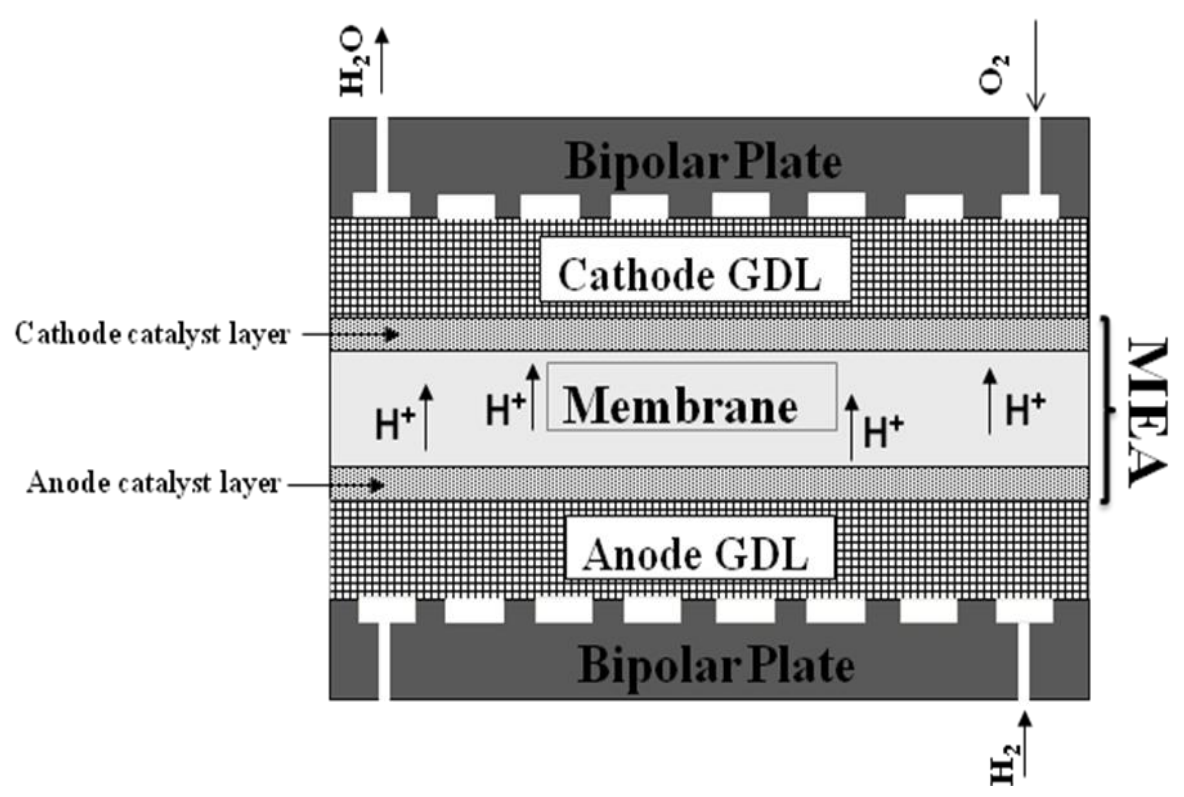

Fig. 1. Basic schematic of a Proton exchange membrane fuel cell. 


$$
\begin{aligned}
& \mathrm{H}_{2} \rightarrow 2 \mathrm{H}^{+}+2 \mathrm{e}^{-} \\
& 1 / 2 \mathrm{O}_{2}+2 \mathrm{e}^{-}+2 \mathrm{H}^{+} \rightarrow \mathrm{H}_{2} \mathrm{O}
\end{aligned}
$$

The transport of gases, charged species and water can be better understood by taking a closer look at the electrode structure. A schematic of the cathode electrode is illustrated in Fig. 2. An effective electrode is one that optimally balances the transport processes required for an operational fuel cell. The four transport processes required are the transport of:

1. The reactant and product gases between the catalyst layer and the gas channels respectively.

2. Electrons between the current collector and the catalyst layer through the gas diffusion layer

3. Protons from/to the membrane and the catalyst layer

4. Protons through the membrane from the anode to the cathode

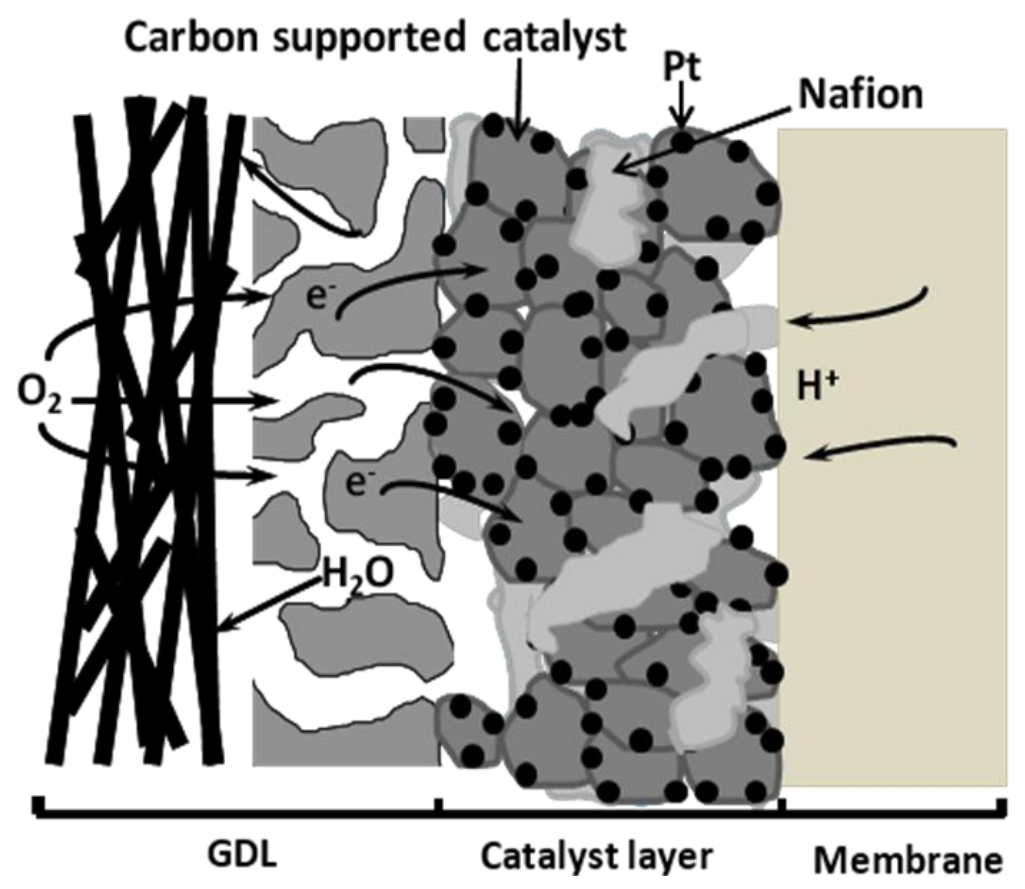

Fig. 2. Transport of gases, protons, and electrons in a PEM fuel cell electrode.

The reactant gases, the solid catalysts and the electrolyte are often referred to as the three phases found in a catalyst layer. Part of the optimization of an electrode design is the attempt to distribute the appropriate amount of catalyst layer and the volume between the transport media for each of the three phases to reduce transport losses. In addition, an intimate intersection of these transport processes at the catalyst particles is vital for effective 
operation of a PEM fuel cell. Therefore the assembly of the electrode and the membrane with optimum three-phase reaction structure termed as the membrane electrode assembly (MEA), is crucial for the success of this technology and is rightly called "the core of the fuel cell".

The main components of a PEMFC MEA are: (i) Proton conducting membranes, (ii) electro-catalysts (anode and cathode), (iii) porous gas diffusion electrodes, and (iv) the assembly of membrane and electrodes

\subsection{Proton conducting membranes}

The proton conducting membrane (PCM) is one of the vital components of the MEA, conducting only protons through them and acting as a barrier between the reactants and electrons and thereby making the PEMFC possible to attain high power densities.

The desired properties for a membrane to be used as a proton conductor in a fuel cell are listed in the following:

1. Good chemical, mechanical and electrochemical stability in fuel cell operating conditions

2. Elevated proton conductivity to support high currents with minimal resistive losses and zero electronic conductivity

3. Thermal and hydrolytic stability

4. Chemical properties compatible with the bonding requirements of membrane with the electrodes

5. No permeability to reactant species to maximize efficiency

6. High durability and low costs membranes

A number of polymer materials have be studied as PCMs for PEMFC applications. Fig. 3 gives the classification of the membrane materials studied so far. The results from these studies are highlighted and described in detail below. 


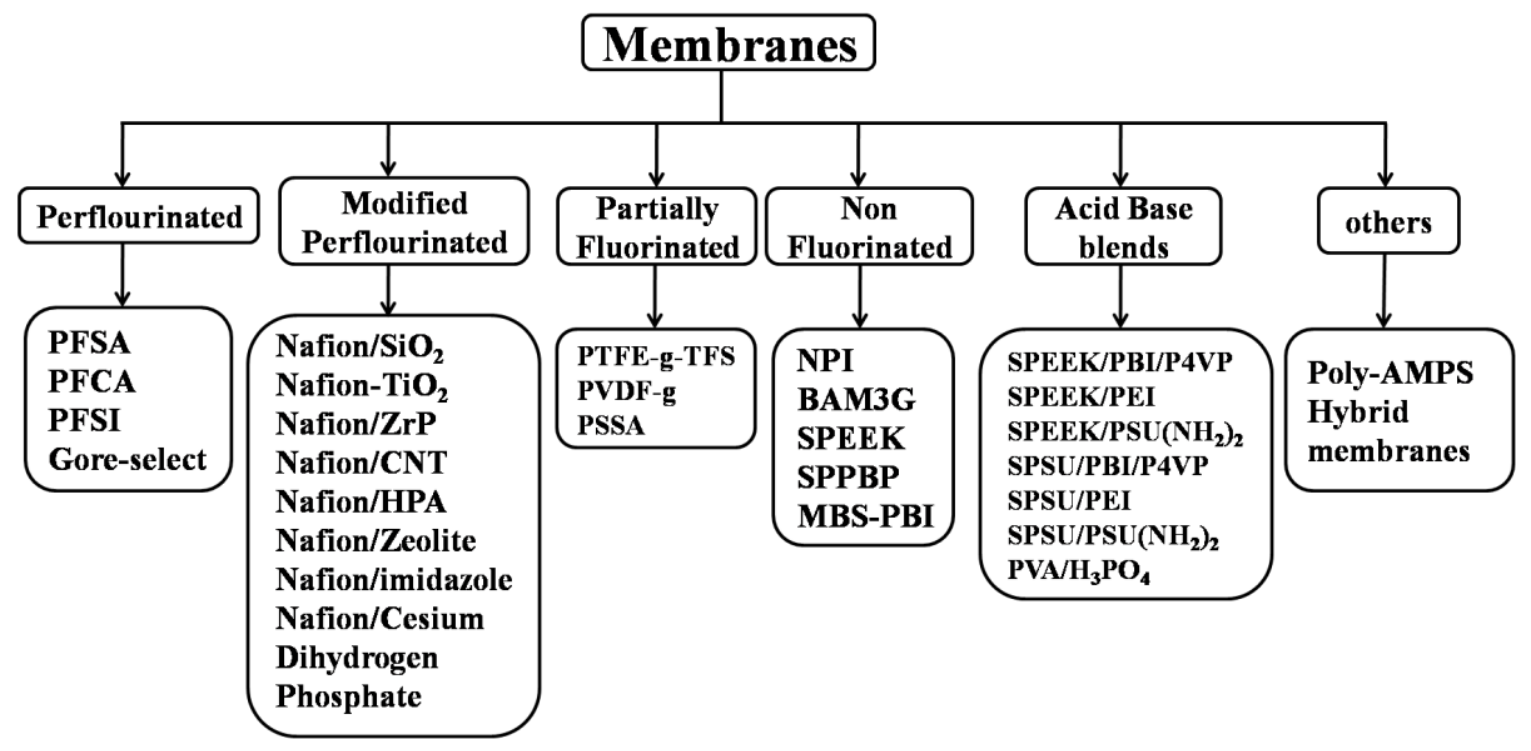

Fig. 3. Classification of PCMs.

\subsubsection{Perfluorinated membranes}

A remarkable advancement in the PEMFC technology, was when the polystyrene sulfonic acid membrane (the electrolyte in the general electric $1 \mathrm{~kW}$ solid polymer electrolyte fuel cell (SPEFC), used as an auxiliary power source in every one of NASA's Gemini flights in the 1960s, was replaced by Du Pont's perfluorosulfonic acid membrane $\left(\mathrm{Nafion}^{\circledR}\right)$ in the 1970s [11]. Perfluorosulfonic acid membranes are highly conductive to protons and their stability in acid environment is much better as compared to polystyrene sulfonic acid membranes.

Nafion, the commercially available Perfluorosulfonic acid membrane is widely used in PEMFCs due to their high proton conductivity and moderate swelling in water. Perfluorosulfonic acid membrane (PFSA) consists of three functional regions: (1) a polytetrafluoroethylene (PTFE, DuPont's Teflon ${ }^{\mathrm{TM}}$ )-like backbone, (2) side chains of --fluorinated carbon which connect the molecular backbone to the third region, and (3) ion clusters in the third region consisting of sulfonic acid ions. When the membrane becomes hydrated, the hydrogen ions in the third region become mobile by bonding to the water molecules and move between sulfonic acid sites (Fig 4). There are two advantages to use PFSA membranes in PEM fuel cells. First, because the structure is based on PTFE backbone, PFSA membranes are relatively strong and stable in both oxidative and reductive environments. In fact, durability of $60,000 \mathrm{~h}$ has already been reported [12]. Second, the protonic conductivities achieved in a well-humidified PFSA membrane can be as high as $0.2 \mathrm{~S} / \mathrm{cm}$ at PEM fuel cell operating temperatures. The high electronegativity (i.e. electron affinity) of the fluorine atom, bonded to the same carbon atom as the $\mathrm{SO}_{3} \mathrm{H}$ group makes the sulfonic acid a superacid (e.g. like the trifluoromethane sulfonic acid). Thus, there is at least a two-fold increase in the specific conductivity of this membrane material as compared 
with the polystyrene sulfonic acids, which translates to a cell resistance as low as $0.21 \Omega \mathrm{cm}^{2}$ for a $100 \mu \mathrm{m}$ thick membrane with voltage loss of only $50 \mathrm{mV}$ at $1 \mathrm{~A} / \mathrm{cm}^{2}$ (Table 1 ).

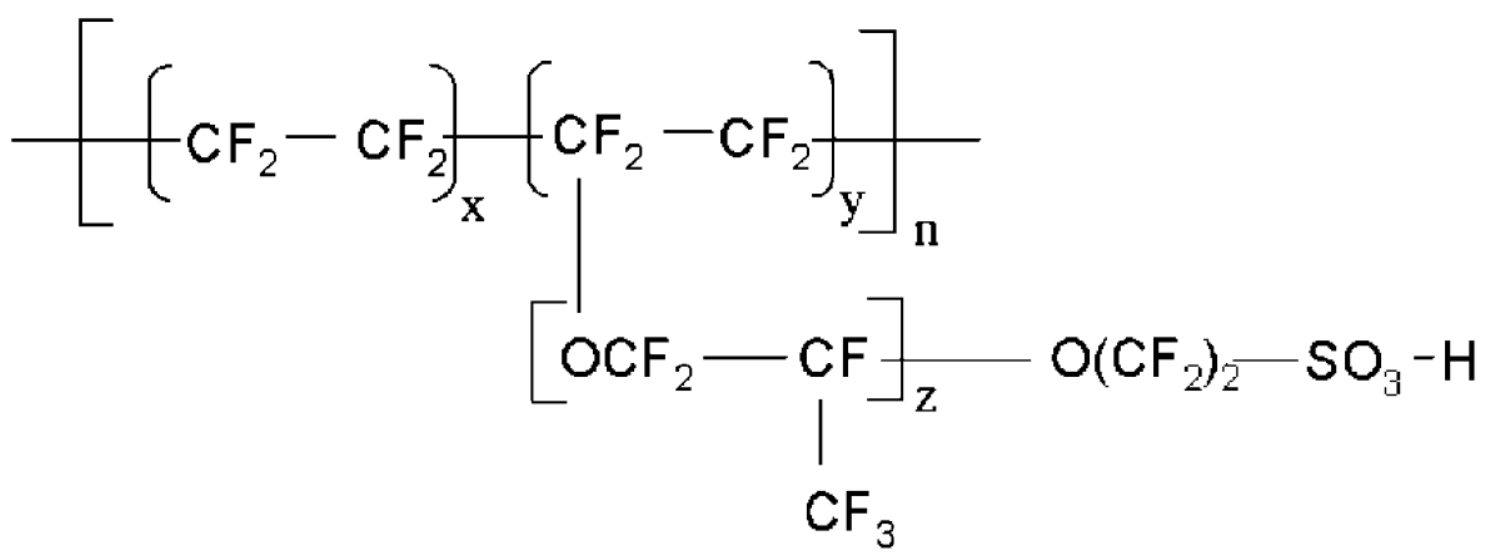

Fig. 4. Chemical structure of Nafion

The proton conductivity in Nafion is strongly dependent upon its water content. At high humidity, proton transport through the membrane is based on non-classical mechanisms such as Grotthuss transport or structural diffusion in which protons transfer along the hydrogen bond network [14-16]. At lower humidity, the proton transport is based on the surface mechanism in which protons move under the electrostatic effects provided by the sulfonate groups. Proton dynamics can be characterized mostly as proton motion around a sulfonate group, with occasional movement to a neighboring sulfonate group [17].

Various types of Nafion membranes, such as Nafion 117, 115, 112 and 105, were tested as electrolyte within the single cell and at different temperatures, among which Nafion 112 gave the optimal result. Table 1 Shows the electrode kinetic parameters at $50^{\circ} \mathrm{C}$, calculated from the polarization curves for the PEMFC single cell with different Nafion electrolyte membranes [18].

Table 1. Electrode kinetic parameters at $50^{\circ} \mathrm{C}$, calculated from the polarization curves for a PEMFC single cell.

\begin{tabular}{|l|l|l|l|l|l|}
\hline Membrane & $\begin{array}{c}\text { Dry } \\
\text { thickness } \\
(\mu \mathrm{m})\end{array}$ & $\begin{array}{c}\text { Equivalent } \\
\text { weight }\end{array}$ & \multicolumn{1}{|c|}{$\mathrm{E}_{0}(\mathrm{~V})$} & $\mathrm{R}\left(\Omega \mathrm{cm}^{2}\right)$ & \multicolumn{1}{|c|}{$\begin{array}{c}\text { Exchange } \\
\text { current density } \\
\left(\mathrm{i}_{0}, \mathrm{mV} \mathrm{dec}^{-1}\right)\end{array}$} \\
\hline Nafion 112 & 50 & 1100 & 0.99 & 0.11 & 56.0 \\
\hline Nafion 115 & 125 & 1100 & 1.01 & 0.26 & 62.0 \\
\hline Nafion 117 & 175 & 1100 & 1.02 & 0.33 & 68.0 \\
\hline
\end{tabular}


The Dow Chemical Company and Asahi Chemical Company synthesized advanced perfluorosulfonic acid membranes with shorter side chains and a higher ratio of $\mathrm{SO}_{3} \mathrm{H}$ to $\mathrm{CF}_{2}$ groups [12]. The most widely used class of membrane materials today for the PEFC are of the perfluorinated sulfonic acid (PFSA) type, e.g., Nafion ${ }^{\circledR}$ (Dupont, USA), Flemion ${ }^{\circledR}$ (Asahi Glass, Japan), Aciplex ${ }^{\circledR}$ (Asahi Kasei, Japan), and derivatives thereof, such as the GORE-SELECT® membranes (W.L. Gore, USA). The thickness of the Gore membranes is 25-35 $\mu \mathrm{m}$. Table 2 provides a comparison of the properties of known commercial cationexchange membranes for PEMFCs [13]. The lower equivalent weights of these membranes compared to Nafion account for their higher specific conductivities, which enabled significant improvements in PEMFC performance [12] i.e. about $50-100 \mathrm{mV}$ increase in cell potential at $1 \mathrm{~A} \mathrm{~cm}^{-2}$ over that of $\mathrm{Nafion}^{\circledR} 115$, with about the same thickness $(\sim 100 \mu \mathrm{m})$.

Table 2. Properties of commercial cation-exchange membranes [13].

\begin{tabular}{|c|c|c|c|c|c|}
\hline Manufacturer & Membrane type & Trade name & $\begin{array}{c}\text { IEC } \\
\text { (mequiv./ } \\
\text { g) } \\
\end{array}$ & $\begin{array}{c}\text { Thicknes } \\
\text { s } \\
(\mu \mathrm{m})\end{array}$ & $\begin{array}{c}\text { Conductivi } \\
\text { ty } \\
(\mathrm{S} / \mathrm{cm})^{*}\end{array}$ \\
\hline $\begin{array}{l}\text { Asahi } \\
\text { Chemical }\end{array}$ & \multirow{3}{*}{$\begin{array}{l}\text { Sulfonated } \\
\text { polyarylene }\end{array}$} & K 101 & $1 \cdot 4$ & 240 & $0 \cdot 0114$ \\
\hline \multirow{3}{*}{ Asahi Glass } & & $\mathrm{CMV}$ & 2.4 & 150 & 0.0051 \\
\hline & & DMV & $\mathrm{N} / \mathrm{A}$ & 150 & 0.0071 \\
\hline & Perfluorinated & Flemion & $\mathrm{N} / \mathrm{A}$ & 150 & 0.14 \\
\hline \multirow{2}{*}{$\begin{array}{l}\text { Ionac } \\
\text { Chemical } \\
\text { company }\end{array}$} & \multirow[b]{2}{*}{$\mathrm{N} / \mathrm{A}$} & MC 3470 & 1.4 & 600 & 0.0075 \\
\hline & & MC 3142 & 1.1 & 800 & 0.0114 \\
\hline BALLARD & Perfluorinated & BAM 3G & $\mathrm{N} / \mathrm{A}$ & 140 & $\mathrm{~N} / \mathrm{A}$ \\
\hline \multirow{3}{*}{ Ionics } & \multirow{3}{*}{$\mathrm{N} / \mathrm{A}$} & 61AZL386 & 2.3 & 500 & 0.0081 \\
\hline & & 61AZL389 & 2.6 & 1200 & $\mathrm{~N} / \mathrm{A}$ \\
\hline & & 61CZL386 & 2.7 & 600 & 0.0067 \\
\hline \multirow{9}{*}{ Du Pont } & \multirow{7}{*}{ Perfluorinated } & Nafion $^{\circledR} 105$ & $\mathrm{~N} / \mathrm{A}$ & 125 & $\mathrm{~N} / \mathrm{A}$ \\
\hline & & Nafion $^{\circledR} 112$ & $\mathrm{~N} / \mathrm{A}$ & 50 & 0.065 \\
\hline & & Nafion $^{\circledR} 1135$ & $\mathrm{~N} / \mathrm{A}$ & 89 & 0.11 \\
\hline & & Nafion ${ }^{\circledR} 115$ & $\mathrm{~N} / \mathrm{A}$ & 127 & 0.09 \\
\hline & & Nafion ${ }^{\circledR} 117$ & 0.9 & 183 & 0.08 \\
\hline & & Nafion $^{(B} 1110$ & $\mathrm{~N} / \mathrm{A}$ & 254 & $\mathrm{~N} / \mathrm{A}$ \\
\hline & & Nafion901 & 1.1 & 400 & 0.01053 \\
\hline & \multirow{2}{*}{$\begin{array}{l}\text { Perfluro } \\
\text { sulfonic } \\
\text { acid/PTFE } \\
\text { copolymer }\end{array}$} & NRE-211 & $\mathrm{N} / \mathrm{A}$ & 25.4 & 0.1 \\
\hline & & $\mathrm{NRE} 2{ }^{\circledR} 12$ & $\mathrm{~N} / \mathrm{A}$ & 50.8 & 0.1 \\
\hline Dow Chemical & Perfluorinated & Dow & $\mathrm{N} / \mathrm{A}$ & 125 & 0.114 \\
\hline
\end{tabular}




\begin{tabular}{|c|c|c|c|c|c|}
\hline company & & & & & \\
\hline \multirow[b]{2}{*}{$\begin{array}{l}\text { Pall Gelman } \\
\text { sciences }\end{array}$} & $\begin{array}{l}\text { Tetra- } \\
\text { fluoroethylene } \\
\text { grafted } \\
\text { poly(styrene } \\
\text { sulfonic acid) }\end{array}$ & $\begin{array}{l}\operatorname{IonClad}^{\circledR} \mathrm{R} \\
1010\end{array}$ & $\mathrm{~N} / \mathrm{A}$ & 40 & 0.07 \\
\hline & $\begin{array}{l}\text { Tetrafluoroethyle } \\
\text { ne/ } \\
\text { perfluoropropyle } \\
\text { ne } \\
\text { copolymer }\end{array}$ & $\begin{array}{l}\text { IonClad }^{\circledR} \mathrm{R} \\
1010\end{array}$ & $\mathrm{~N} / \mathrm{A}$ & 20 & 0.08 \\
\hline $\begin{array}{l}\text { David Fuel } \\
\text { Cell } \\
\text { Components }\end{array}$ & $\begin{array}{l}\text { Perflurosulfonic } \\
\text { acid }\end{array}$ & Sterion ${ }^{\circledR}$ L180 & $\mathrm{N} / \mathrm{A}$ & 180 & $\mathrm{~N} / \mathrm{A}$ \\
\hline Gore Select & $\begin{array}{l}\text { Perflurosulfonic } \\
\text { acid }\end{array}$ & Gore & $\mathrm{N} / \mathrm{A}$ & $5-20$ & $0.028-0.096$ \\
\hline \multirow[b]{2}{*}{ Solvay } & $\begin{array}{l}\text { Polyethylene- } \\
\text { Tetrafluoroethyle } \\
\text { ne grafted } \\
\text { sulphonyls }\end{array}$ & CRA & $\mathrm{N} / \mathrm{A}$ & 160 & 0.045 \\
\hline & $\begin{array}{l}\text { Tetra } \\
\text { fluoroethylene } \\
\text { with poly(styrene } \\
\text { sulfonic acid) }\end{array}$ & CRS & $\mathrm{N} / \mathrm{A}$ & 160 & 0.05 \\
\hline $3 \mathrm{M}$ & Perfluorinated & $3 \mathrm{M}$ & $\mathrm{N} / \mathrm{A}$ & 30 & $\begin{array}{l}0.17[70-80 \\
\left.{ }^{\circ} \mathrm{C}\right]\end{array}$ \\
\hline Fumatech & $\begin{array}{l}\text { Perfluorinated/n } \\
\text { on-perfluorinated }\end{array}$ & Fumapem & $\mathrm{N} / \mathrm{A}$ & $30-60$ & $\mathrm{~N} / \mathrm{A}$ \\
\hline
\end{tabular}

*at $30^{\circ} \mathrm{C}$ and $100 \%$ relative humidity.

In spite of the advantages which lead to a number of commercial entities marketing PFSA membranes, there are some disadvantages of using PFSA membranes in PEM fuel cells. One major disadvantage with perfluorosulfonic-acid (PFSA) membranes has been, and still is, is their high cost (approx US $\$ 700 \mathrm{~m}^{-2}$ ). This is due to the expensive fluorination step and lengthy preparation period required for manufacture of PFSA membranes [19].

Substantial efforts are made by both academia and industry to develop novel fuel cell membrane materials, mainly driven by the need for cheaper membranes with improved functionality (e.g., conductivity, robustness) and. Promising alternatives are partially fluorinated or non-fluorinated ionomer containing aromatic units with- $\mathrm{SO}_{3} \mathrm{H}$ groupsin the main polymer chain, or in the side chain. 


\subsubsection{Modified PFSA Membranes}

Considerable efforts are being made to modify the PFSA membranes to reduce the costs and to achieve high temperature operation. One approach is to replace water with low volatile non aqueous solvent that serves the same function as water, facilitate proton transfer. Two salient examples of such 'water replacements' are phosphoric acid and imidazole. This approach has met with limited success. The other approach is to develop methods to improve water management. As the water generated within the fuel cell is not sufficient enough to hydrate the membrane, usually the PFSA membranes are supplied with water along with reactants (humidification) increasing the complexity of PEMFC systems [20].

Accordingly, approaches have been to develop PEMFC systems operating with low humidification at both low $\left(80^{\circ} \mathrm{C}\right)$ and high (above $\left.100^{\circ} \mathrm{C}\right)$ temperatures. These approaches include reducing the thickness of membranes, impregnating the membranes with hygroscopic oxide nanoparticles, and introducing solid inorganic proton conductors. This approach might lead to better fuel cell performance if the composition and morphology of the additive and composite are well-designed.

Two common methods that are employed to prepare nafion modified composite membranes are: (i) direct addition of particles to a solution of Nafion, followed by casting; and (ii) sol gel approach to incorporate inorganic oxide nanoparticles within the pores of Nafion membrane. The membranes synthesized by sol gel approach were completely transparent and homogenous as compared to membranes prepared by alternate casting methods which were cloudy due to large particle size of the additives. The fuel cell performance of several modified PFSA membranes are summarized in Table 3.

On analyzing the table, it can be concluded that nafion-silica composite is among the extensively studied membranes in the modified PFSA category [21-24]. The conductivity of nafion-silica composite membrane decreases with increasing $\mathrm{SiO}_{2}$ content and is lower than the conductivity of nafion. However, at elevated temperatures (above $80^{\circ} \mathrm{C}$ ), modified nafion-silica membranes exhibit a higher conductivity than nafion, reaching $10^{-4}$ to $^{-7} 0^{-7} \mathrm{Scm}^{-1}$ at $100^{\circ} \mathrm{C}$ [23]. Further, hybrid nafion-silica membranes doped with heteropolyacids have also been reported. The performance of nafion-silica composite membranes in the PEMFC operated at $110{ }^{\circ} \mathrm{C}$ and $70 \% \mathrm{RH}$ is better than that of nafion and is found to be in the order of nafion $/ \mathrm{SiO}_{2} / \mathrm{PWA}>\mathrm{Nafion} / \mathrm{SiO}_{2}>\mathrm{Nafion} / \mathrm{WO}_{3}>\mathrm{Nafion} / \mathrm{TiO}_{2}$ [31].

The $\mathrm{ZrO}_{2}$-Nafion membrane showed higher proton conductivity and better water uptake as compared to Nafion at the same temperature and humidity. $\mathrm{ZrO}_{2}-\mathrm{Nafion}$ composites have strong acid sites and higher bulk to surface water ratio, which is critical for higher proton conductivity and better fuel cell performance. $\mathrm{ZrO}_{2}$-Nafion membranes have showed better fuel cell performance at $80{ }^{\circ} \mathrm{C}$ as compared to other membranes [26].

Nafion-ZrP composite membrane based on a commercial Nafion-115 membrane exhibited a performance of $1000 \mathrm{~mA} \mathrm{~cm}{ }^{-2}$ at $0.45 \mathrm{~V}$ [24], whereas an unmodified membrane exhibited a performance of $250 \mathrm{~mA} \mathrm{~cm}{ }^{-2}$ for an $\mathrm{H}_{2} / \mathrm{O}_{2}$ PEMFC at $130{ }^{\circ} \mathrm{C}$ and at 3 bars. With the same 
operating conditions, the cell performance was $1.5 \mathrm{~A} \mathrm{~cm}^{-2}$ for the recast composite membrane [34]. The recast composite membranes showed a stable behavior when maintained at $130{ }^{\circ} \mathrm{C}$, while non-composite membranes show irreversible degradation. The proton conductivity of recast composite membrane was found to be similar to that of pure Nafion and Nafion-ZrP.

Keggin-type heteropolyacids, like phosphotungstic acid (PTA) and silicotungstic acid (STA), with high water content exhibits high conductivity at room-temperature. Nafionheteropolyacid exhibits higher proton conductivity at temperatures above $100^{\circ} \mathrm{C}$ at low humidity [33]. Zeolites and mineral clays are good prospective materials for such modification of Nafion membranes. High surface acidity of zeolites and clays affords a high level of proton conductivity. Moreover, embedded zeolites can maintain a high water uptake even at temperatures above $100^{\circ} \mathrm{C}$ [38]. Carbon nanotubes were also used to improve the mechanical properties of Nafion and the transport characteristics of $50 \mu \mathrm{m}$ composite membranes containing 1\% nanotubes were close to that of Nafion NRE-212, but the mechanical characteristics were better $[43,44]$.

Table 3 also summarizes modified Nafion with different inorganic additives/fillers to allow PEMFC operation at higher temperatures and low relative humidity values [25]. Solid-acid proton conductors like zirconium phosphate, titanium phosphate, cesium phosphates and heteropoly acids have also been explored as additives to Nafion, to facilitate proton transport at reduced or zero hydration levels in the matrix.

Nafion-inorganic composite membranes exhibit lower resistance and hence PEMFCs with such membranes sustain higher load current-densities particularly under low relative humidity conditions in relation to the pristine-Nafion membranes. These membranes help PEMFCs to sustain periods of inlet-stream draught without excessive loss in membrane conductivity. Consequently, the challenges associated with humidification requirements for PEMFCs in an operating system are partly mitigated, which helps cutting system complexity and hence it's cost [27].

Blending Nafion with other polymeric materials has also been tried by some researchers with limited success. 
Table 3. Summary of modified PFSA membranes.

\begin{tabular}{|c|c|c|c|c|}
\hline $\begin{array}{l}\text { Membranes } \\
\text { [Ref] }\end{array}$ & $\begin{array}{l}\text { Water } \\
\text { uptake } \\
(\%)\end{array}$ & $\begin{array}{l}\text { Conductivity } \sigma \\
\qquad(\mathrm{S} / \mathrm{cm}) \\
\left\{\text { Temp in }^{\circ} \mathrm{C}\right\} \\
{[\mathrm{RH} \%]}\end{array}$ & $\begin{array}{l}\text { Comments on } \\
\text { Ionic conductivity }\end{array}$ & Fuel cell performance \\
\hline $\begin{array}{l}\mathrm{Nafion}^{\circledR}-\mathrm{SiO}_{2} \\
{[23,31]}\end{array}$ & 34 & $1.07 \times 10^{-2}$ & $\begin{array}{l}\text { Conductivity slightly lower } \\
\text { to Nafion, improved } \\
\text { conductivity than nafion at } \\
\text { elevated temperatures }\end{array}$ & $i_{0.4 \mathrm{~V}}=320 \mathrm{~mA} / \mathrm{cm}^{2}$ \\
\hline $\begin{array}{l}\text { Nafion } / \mathrm{SiO}_{2} / \\
\text { PWA [31] }\end{array}$ & 38 & $2.6 \times 10^{-2}$ & $\begin{array}{l}\text { Higher conductivity than } \\
\text { nafion at lower RH }\end{array}$ & $i_{0.4 \mathrm{~V}}=540 \mathrm{~mA} / \mathrm{cm}^{2}$ \\
\hline $\begin{array}{l}\mathrm{Nafion}^{\circledR} / \\
\mathrm{ZrO}_{2}[28]\end{array}$ & 24 & $2 \times 10^{-2}$ & $\begin{array}{l}\text { Conductivity slightly lower } \\
\text { to Nafion, improved } \\
\text { conductivity at elevated } \\
\text { temperatures }\end{array}$ & $\begin{array}{l}i_{0.6 \mathrm{v}}=604 \mathrm{~mW} / \mathrm{cm}^{2}(110 \circ \mathrm{C}, 100 \% \\
\mathrm{RH}) \\
i_{0.6 \mathrm{~V}}=387 \mathrm{~mW} / \mathrm{cm}^{2}(130 \circ \mathrm{C}, 85 \% \\
\mathrm{RH})\end{array}$ \\
\hline $\begin{array}{l}\mathrm{Nafion}^{\circledR} / \\
\text { sulfated } \mathrm{ZrO}_{2} \\
{[29]}\end{array}$ & 27 & $2.3 \times 10^{-1}$ & $\begin{array}{l}\text { Higher conductivity than } \\
\text { nafion at elevated } \\
\text { temperatures }\end{array}$ & $\begin{array}{l}\text { Nafion/ S- } \mathrm{ZrO}_{2}=1.35 \mathrm{~W} / \mathrm{cm}^{2}\left(80^{\circ} \mathrm{C}\right) \\
\text { Nafion } / \mathrm{S}-\mathrm{ZrO}_{2}=0.99 \mathrm{~W} / \mathrm{cm}^{2} \\
\left(120^{\circ} \mathrm{C}\right) \\
\text { Nafion }=1.28 \mathrm{~W} / \mathrm{cm}^{2}\left(80^{\circ} \mathrm{C}\right) \\
\text { Nafion }=0.75 \mathrm{~W} / \mathrm{cm}^{2}\left(120^{\circ} \mathrm{C}\right)\end{array}$ \\
\hline $\begin{array}{l}\mathrm{Nafion}^{\circledR} / \mathrm{TiO}_{2} \\
{[30]}\end{array}$ & $\begin{array}{l}(29 \\
\{\end{array}$ & $\begin{array}{l}0.15-0.18(85) \\
{[100]}\end{array}$ & $\begin{array}{l}\text { Conductivity slightly lower } \\
\text { to Nafion, improved } \\
\text { conductivity at elevated } \\
\text { temperatures }\end{array}$ & $\begin{array}{l}i_{0.56 \mathrm{~V}}=514 \mathrm{~mW} / \mathrm{cm}^{2}\left(110^{\circ} \mathrm{C}\right) \\
i_{0.56 \mathrm{~V}}=256 \mathrm{~mW} / \mathrm{cm}^{2}(130 \circ \mathrm{C})\end{array}$ \\
\hline $\begin{array}{l}\mathrm{Nafion}^{\circledR} / \mathrm{WO}_{3} \\
{[31,32]}\end{array}$ & $(37)$ & $10^{-2}(100)$ & $\begin{array}{l}\text { Lower resistance than } \\
\text { Nafion due to spillover } \\
\text { effect }\end{array}$ & $\begin{array}{l}\text { Better performance than Nafion } 112 \\
i_{0.4 \mathrm{~V}}=300 \mathrm{~mA} / \mathrm{cm}^{2}\end{array}$ \\
\hline $\begin{array}{l}\text { Nafion }^{\circledR} / \text { PTA, } \\
\text { PMA, STA, } \\
\text { SMA [33] }\end{array}$ & $(8)$ & $\begin{array}{l}0.06-0.08(70) \\
{[100]}\end{array}$ & $\begin{array}{l}\text { Improved conductivity over } \\
\text { Nafion. But suffers leaching } \\
\text { of HPA }\end{array}$ & $i_{0.6 \mathrm{~V}}=0.1-0.9 \mathrm{~A} / \mathrm{cm}^{2}\left(80^{\circ} \mathrm{C}, 75 \% \mathrm{RH}\right)$ \\
\hline $\begin{array}{l}\text { Nafion }^{\circledR} / \mathrm{ZrP} \\
{[34,24]}\end{array}$ & $\mathrm{N} / \mathrm{A}$ & $0.025[92]$ & $\begin{array}{l}\text { Conductivity similar to } \\
\text { Nafion, improved } \\
\text { conductivity at elevated } \\
\text { temperatures }\end{array}$ & $i_{0.45 \mathrm{~V}}=1000 \mathrm{~mA} / \mathrm{cm}^{2}[24]$ \\
\hline $\begin{array}{l}\text { Nafion }^{\circledR} / \text { PTF } \\
\text { E/zirconium } \\
\text { phosphate }[35, \\
\text { 36] }\end{array}$ & $\mathrm{N} / \mathrm{A}$ & $\begin{array}{l}2.38 \times 10^{-3}(70- \\
80)\end{array}$ & $\mathrm{N} / \mathrm{A}$ & Contradicting performances reported \\
\hline $\begin{array}{l}\text { Nafion }^{\circledR} / \mathrm{ZrSP} \\
\mathrm{P}[37]\end{array}$ & $\mathrm{N} / \mathrm{A}$ & $10^{-1}(110)[98]$ & $\mathrm{N} / \mathrm{A}$ & $\begin{array}{l}\text { High performance- } \\
i_{0.4 \mathrm{~V}}=700 \mathrm{~mA} / \mathrm{cm}^{2}\left(100^{\circ} \mathrm{C}\right)\end{array}$ \\
\hline
\end{tabular}




\begin{tabular}{|c|c|c|c|c|}
\hline $\begin{array}{l}\text { Nafion }^{\circledR} \\
\text { /Zeolite [38] }\end{array}$ & (30) & $0.14(\mathrm{RT})$ & $\mathrm{N} / \mathrm{A}$ & $\mathrm{N} / \mathrm{A}$ \\
\hline $\begin{array}{l}\operatorname{Nafion}^{\circledR} / \text { mord } \\
\text { enite [39] }\end{array}$ & $(38.6)$ & $0.01(70)[100]$ & $\begin{array}{l}\text { Very small conductivity } \\
\text { improvements at high } \\
\text { temperatures only }\end{array}$ & $i_{0.5 \mathrm{v}}=400 \mathrm{~mA} / \mathrm{cm}^{2}\left(100^{\circ} \mathrm{C}\right)$ \\
\hline $\begin{array}{l}\operatorname{Nafion}^{\circledR} / \text { cesiu } \\
\text { m } \\
\text { phosphate[40] }\end{array}$ & $\mathrm{N} / \mathrm{A}$ & $\mathrm{N} / \mathrm{A}$ & $\begin{array}{l}\text { Conductivity similar to } \\
\text { Nafion, improved } \\
\text { conductivity at elevated } \\
\text { temperatures }\end{array}$ & $\mathrm{N} / \mathrm{A}$ \\
\hline $\begin{array}{l}\mathrm{Nafion}^{\circledR} / \mathrm{SiO}_{2-} \\
\mathrm{Cs}_{2.5} \mathrm{H}_{0.5} \mathrm{PWO}_{4} \\
{ }_{0}[41]\end{array}$ & (34) & $\mathrm{N} / \mathrm{A}$ & $\mathrm{N} / \mathrm{A}$ & $\begin{array}{l}\text { Better performance than Nafion }{ }^{\circledR} \\
\text { NRE- } 212 \text { membrane under fully } \\
\text { humidified and dry conditions }\end{array}$ \\
\hline $\begin{array}{l}\text { Nafion }^{\circledR} / \text { imida } \\
\text { zole [42] }\end{array}$ & $\mathrm{N} / \mathrm{A}$ & $\mathrm{N} / \mathrm{A}$ & $\begin{array}{l}\text { Very good conductivity } \\
\text { results however imidazole } \\
\text { poisoned } \mathrm{Pt} \\
\text { catalyst }\end{array}$ & $\mathrm{N} / \mathrm{A}$ \\
\hline $\begin{array}{l}\mathrm{Nafion}^{\circledR} / \mathrm{CNT} \\
{[43,44]}\end{array}$ & $(22.18)$ & $\mathrm{N} / \mathrm{A}$ & $\begin{array}{l}\text { Enhanced proton } \\
\text { conductivity and mechanical } \\
\text { strength leading to better } \\
\text { PEFC performance }\end{array}$ & $\begin{array}{l}\text { Better performance than Nafion }{ }^{\circledR} \\
\text { NRE- } 212 \text { membrane }\end{array}$ \\
\hline $\begin{array}{l}\mathrm{Nafion}^{\circledR} / \mathrm{PAN} \\
\text { I [45] }\end{array}$ & $\mathrm{N} / \mathrm{A}$ & $\mathrm{N} / \mathrm{A}$ & $\begin{array}{l}\text { Higher conductivity than } \\
\text { nafion at lower } \mathrm{RH}\end{array}$ & $\begin{array}{l}\text { Better performance than Nafion } 112 \\
\text { membrane at low humidity }\end{array}$ \\
\hline
\end{tabular}

RH = Relative Humidity

\subsubsection{Partially fluorinated Membranes}

The high cost of perfluoro sulfonic acid membranes, as mentioned earlier, is mainly due to the expensive fluorination step. Thus, partially-fluorinated and non-fluorinated ionomer membranes are currently under study to address the cost issues of the PCMs. Also there are safety concerns associated with fluorinated membranes, where toxic and corrosive gases are liberated at temperatures above $423 \mathrm{~K}[46,47]$.

As a low-cost synthesis technique for Nafion-alternative PCMs, a radiation-induced grafting method has attracted much attention. Radiation-grafted membranes, with varying amounts of fluoride containing aliphatic backbone and poly (styrene sulfonic acid) side chains, can belong to either of these groups depending on the composition of the polymer backbone. Radiation-grafted membranes have been shown to have interesting properties for fuel cell applications. In particular, conductivities and gas permeabilities comparable to those of the 
commercial Nafion membranes can be obtained. The major problem currently appears to be the durability in the fuel cell as very varying lifetimes have been reported $[48,49]$.

Several research groups have investigated this type of membrane with their own starting materials and preparation methods and studied their properties as a function of degree of grafting or the ion exchange capacity. Poly (vinylidene fluoride), PVDF [50, 51], Poly (ethylene-alttetrafluoroethylene), ETFE [51], and poly (tetrafluoroethylene-coperfluorovinylether), PFA [52], have been used as the starting polymer matrix for radiation grafting membranes. However, as the preparation conditions are expected to affect the membrane properties [53], comparing the results reported by different groups will be futile. $\mathrm{Li}$ et al. performed fuel-cell tests with $\mathrm{H}_{2}-\mathrm{O}_{2}$, using crosslinked-PTFE based radiationgrafted PEMs, and then reported that their cell performance exceeded that of Nafion [54]. Partially fluorinated polymers are listed in Table 5 and a detailed review by Gubler et al [55] is available on radiation grafted membranes for polymer electrolyte fuel cells. According to Gubler et al. [55], membranes with high grafting levels have a poor long-term stability. Another issue is to transform well-conducting grafted membranes into well-performing MEAs as the surface of grafted membranes appears to be quite hydrophobic, leading to poor contact with Nafion impregnated gas diffusion electrodes.

\subsubsection{Non fluorinated Membranes}

Non fluorinated hydrocarbon polymer membranes (Table 4), principally motivated to lower the material cost of commercial perfluorinated membranes are also being developed to facilitate high temperature operation. A large amount of literature is available on alternative Non fluorinated membranes to perfluorinated materials which includes: (a) polysulfones (PSF) (b) poly ethersulfone (PES) (c) polyetheretherketone (PEEK) (d) acid functionalized or doped poly (benzimidazole) (e) poly(phynelene oxides) (f) poly(phosphazenes) etc

Besides improved water retention at high temperatures, attempts were made to improve the morphology of these ionomer-based membranes. The chemical structure and the membrane morphology are important for the fuel cell performance, and is linked to the nature of the ionomer and the membrane formation process. The morphology depends strongly on the water content, and on the concentration and distribution of the acidic moieties [61-63]. During the last couple of decades, many researchers have focused on the synthesis of various sulfonated aromatic polymers that have high thermal, chemical and oxidative stability coupled with good mechanical properties and low cost. Usually they are prepared either by post-sulfonation of commercial polymers or by direct synthesis of sulfonated polymer via copolymerization of sulfonated monomers. The latter approach might be a better approach to control the polymer homogeneity and the degree of sulfonation.

Aromatic polyimides show high levels of conductivity, but the hydrolytic stability is reported to be very sensitive to the chemical structure of the polyimide main-chain [66-68]. The fuel cell performance of sulfonated polyimide (SPI) at $70-80{ }^{\circ} \mathrm{C}$ was found to be similar to 
Nafion. The durability of sulfonated polyimides were also investigated. Mercier's group operated a fuel cell using a sulfonated naphthalene dianhydride base polyimide at $60{ }^{\circ} \mathrm{C}$ and $250 \mathrm{~mA} / \mathrm{cm}^{2}$ for 3,000 $\mathrm{h}$ in hydrogen/oxygen (3 bar each) [82]. One possible explanation for the long lifetime of hydrocarbon membranes is their lower gas permeability. SPI is 40 times less permeable to $\mathrm{H}_{2}$ and 10 times less permeable to $\mathrm{O}_{2}$ compared with Nafion. The reduced gas crossover rate may be responsible for the low degradation rate in fuel cell tests. Long-term durability has been demonstrated on SPI and sulfonated polyarylene ether membranes. Both types of membranes successfully sustained 5,000 h of operation under moderate conditions $\left(0.2 \mathrm{~A} \mathrm{~cm}^{-2}, 80^{\circ} \mathrm{C}\right.$, more than $90 \% \mathrm{RH}$, ambient pressure, and no frequent startup/shutdown). Both membranes showed no changes in ion-exchange capacity over time, which indicates that there is no loss of sulfonic acid groups [63, 64].

Aged sulfonated polyarylenes after fuel cell life testing have shown almost no change in membrane thickness, while similar results using Nafion have shown significant thinning [64].Poly (aryloxyphosphazenes) functionalized with phenyl phosphonic acid units have been developed for use in direct methanol fuel cells [71]. Poly aryloxyphosphazenes) having sulfonimide units are also known [72]. Blending and radiation cross linking have been investigated as means to reduce water swelling and methanol permeation of poly (aryloxyphosphazene) ionomers [73].

sPEEK is made up of highly branched, narrow channels for proton conduction and have more dead-end components than the wider, less-branched channels of Nafion. The more extensive hydrophobic-hydrophilic interface region in sPEEK results in greater separation between sulfonic acid functional groups [61].In sulfonated hydrocarbon polymers, the hydrocarbon backbones are less hydrophobic and the sulfonic acid functional groups are less acidic and polar. As a result, the water molecules of hydration may be completely dispersed in the nanostructure of the sulfonated hydrocarbon polymers. Both PFSA and sulfonated hydrocarbon membranes have similar water uptakes at low water activities, whereas at high relative humidity $(100 \%)$. PFSA membranes have a much higher water uptake due to the more polar character of sulfonic acid functional groups. Sulfonated aromatic polymers have different microstructures from those of PFSA membranes [74]. Detailed discussion on synthesis of hydrocarbon ionomers can be found in a review [75].

Sulfonated PEEK-WC membranes with a degree of sulphonation of $15-40 \%$ have been employed in PEM fuel cells. The membranes exhibit electrochemical performances comparable to Nafion membranes [92].

Phosphonic acid and carboxylic acid groups are much weaker acids than sulfonic acid and do not provide protons easily under normal fuel cell operating conditions. The carboxylated polymers, as one would expect showed lower water uptake and lower conductivity in comparison with the sulfonated polymers. Sulfonated high performance polymer systems based on arylene ether, sulfone, and thioether linkages in the backbone have been synthesized and described in literature [70]. These polymer systems are potential candidates 
for fuel cell applications as they exhibit good thermal and chemical stability and high proton conductivity.

Polybenzimidazole (PBI) based proton exchange membranes are successful Non fluorinated Membranes for fuel cell applications.PBI has excellent thermal and mechanical stability Phosphoric acid doped PBI membranes have been extensively studied at Case Western University, USA for high temperature DMFC applications. Phosphoric acid doped PBI membranes high proton conductivity, low electro-osmotic drag, capable of operating at high temperature $\left(T=200^{\circ} \mathrm{C}\right)$ and low gas humidification, low MCO and low cost in comparison with Nafion/perfluorinated ionomers. The major disadvantage is leaching of phosphoric acid is a major concern for $\mathrm{H}_{3} \mathrm{PO}_{4}-\mathrm{PBI}$. [65]. The performance of an MEA from PEMEAS, containing $\mathrm{H}_{3} \mathrm{PO}_{4}-\mathrm{PBI}$ is even at $160^{\circ} \mathrm{C}$ quite low. At $0.7 \mathrm{~V}$, power density is $0.07 \mathrm{~W} / \mathrm{cm}^{2}$; at $0.6 \mathrm{~V}$, it is $0.25 \mathrm{~W} / \mathrm{cm}^{2}[69]$.

Table 4. Partially fluorinated and Non fluorinated Membranes for PEMFC [76].

\begin{tabular}{|c|c|c|c|c|c|}
\hline Partially fluorinated Polymers & $\begin{array}{l}\text { IEC } \\
\text { (mequiv } \\
\mathrm{g}^{-1} \text { ) }\end{array}$ & $\begin{array}{l}\text { Membrane } \\
\text { Thickness } \\
(\mu \mathrm{m})\end{array}$ & $\begin{array}{l}\text { Conductivity } \\
\qquad(\mathrm{S} / \mathrm{cm}) \\
{[\mathrm{RH} 100 \%]}\end{array}$ & 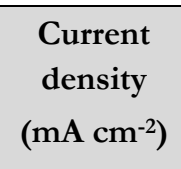 & $\begin{array}{l}\text { Life } \\
\text { Time } \\
\text { (h) }\end{array}$ \\
\hline $\begin{array}{l}\text { Poly(ethylene-co-tetrafluoroethylene) } \\
\text { grafted with poly(styrene sulfonic acid) } \\
{[56]}\end{array}$ & 3.22 & $\mathrm{~N} / \mathrm{A}$ & 0.19 & $\begin{array}{l}190(\text { at } 0.6 \\
\text { V) }\end{array}$ & $\mathrm{N} / \mathrm{A}$ \\
\hline $\begin{array}{l}\text { Poly(tetrafluoroethylene-co- } \\
\text { perfluoropropyl vinyl ether) grafted with } \\
\text { poly(styrene sulfonic acid) }+10 \% \text { DVB) }[57]\end{array}$ & $\mathrm{N} / \mathrm{A}$ & $\mathrm{N} / \mathrm{A}$ & 0.040 & $\begin{array}{l}305-665(\text { at } \\
0.6 \mathrm{~V})\end{array}$ & $>4150$ \\
\hline $\begin{array}{l}\text { Poly(tetrafluoroethylene-co- } \\
\text { perfluoropropyl vinyl ether) grafted with } \\
\text { poly(styrene sulfonic acid) }+9 \% \text { DVB })[58]\end{array}$ & $\mathrm{N} / \mathrm{A}$ & $\mathrm{N} / \mathrm{A}$ & 0.1 & $\begin{array}{l}450(\text { at } 0.6 \\
\text { V) }\end{array}$ & 1400 \\
\hline $\begin{array}{l}\text { Poly(vinylidene fluoride) grafted with } \\
\text { poly(styrene sulfonic acid) }[59,60]\end{array}$ & 1.83 & $\mathrm{~N} / \mathrm{A}$ & 0.050 & $\begin{array}{l}135(\text { at } 0.7 \\
\text { V) }\end{array}$ & $\begin{array}{l}130- \\
150\end{array}$ \\
\hline \multicolumn{6}{|l|}{ Non fluorinated Polymers } \\
\hline $\begin{array}{l}\text { Sulfonated (styrene/ ethylene- } \\
\text { butylene/styrene) [77] }\end{array}$ & 1.78 & 60 & 0.04 & $\begin{array}{l}135(\text { at } 0.7 \\
\text { V) }\end{array}$ & $\mathrm{N} / \mathrm{A}$ \\
\hline Sulfonated (butadiene styrene) [78] & 1.85 & 60 & $\mathrm{~N} / \mathrm{A}$ & $\begin{array}{l}327(\text { at } 0.5 \\
\text { V) }\end{array}$ & $\mathrm{N} / \mathrm{A}$ \\
\hline $\begin{array}{l}\text { Sulfonated trifluorostyrene- } \\
\text { trifluorostyrene copolymer [79] }\end{array}$ & 2.5 & $\mathrm{~N} / \mathrm{A}$ & $\mathrm{N} / \mathrm{A}$ & $\begin{array}{l}730(\text { at } 0.6 \\
\text { V) }\end{array}$ & 14000 \\
\hline $\begin{array}{l}\text { Sulfonated polystyrene-block-(ethylene- } \\
\text { co-butylene) } \\
\text { block-sulfonated polystyrene[80] }\end{array}$ & 1.78 & 60 & $\mathrm{~N} / \mathrm{A}$ & $\begin{array}{l}135(\text { at } 0.7 \\
\text { V) }\end{array}$ & $\mathrm{N} / \mathrm{A}$ \\
\hline Sulfonated polyimide $[81,82,83]$ & 1.26 & 70 & $0.004-0.02$ & $\begin{array}{l}500(\text { at } 0.7 \\
\text { V) }\end{array}$ & 3000 \\
\hline
\end{tabular}




\begin{tabular}{|c|c|c|c|c|c|}
\hline & 1.98 & $\mathrm{~N} / \mathrm{A}$ & 0.13 & $\begin{array}{l}\text { 225(at } 0.6 \\
\text { V) }\end{array}$ & $\mathrm{N} / \mathrm{A}$ \\
\hline & 1.98 & $\mathrm{~N} / \mathrm{A}$ & $\mathrm{N} / \mathrm{A}$ & $\begin{array}{l}500(\text { at } 0.6 \\
\text { V) }\end{array}$ & $\mathrm{N} / \mathrm{A}$ \\
\hline \multirow{4}{*}{ Sulfonated poly sulfone $[85,86,40,64]$} & 1.1 & $20-100$ & $0.01\left(80^{\circ} \mathrm{C}\right)$ & $\begin{array}{l}400(\text { at } 0.7 \\
\text { V) }\end{array}$ & $\mathrm{N} / \mathrm{A}$ \\
\hline & $04-2.2$ & $\mathrm{~N} / \mathrm{A}$ & $0.08-0.17$ & $\begin{array}{l}200 \text { (at } 0.7 \\
\text { V) }\end{array}$ & 500 \\
\hline & $\mathrm{N} / \mathrm{A}$ & 30 & 0.09 & $\begin{array}{l}730(\text { at } \\
0.6 \mathrm{~V})\end{array}$ & $\mathrm{N} / \mathrm{A}$ \\
\hline & 1.6 & 50 & $\mathrm{~N} / \mathrm{A}$ & 200 (ocv) & 5000 \\
\hline $\begin{array}{l}\text { Disulfonated biphenol based poly(arylene } \\
\text { ether sulfone) copolymer [87] }\end{array}$ & 1.3 & $\mathrm{~N} / \mathrm{A}$ & 0.03 & $\begin{array}{l}840 \text { (at } 0.6 \\
\text { V) }\end{array}$ & $>800$ \\
\hline \multirow{4}{*}{$\begin{array}{l}\text { Sulfonated poly (aryl ether ketones) } \\
\text { S-PEEK[88][16,89][90] }\end{array}$} & 1.55 & 18 & 0.05 & $\begin{array}{l}730(\text { at } 0.7 \\
\mathrm{V})\end{array}$ & $\mathrm{N} / \mathrm{A}$ \\
\hline & $\mathrm{N} / \mathrm{A}$ & 50 & $\mathrm{~N} / \mathrm{A}$ & $\begin{array}{l}410(\text { at } \\
0.7 \mathrm{~V})\end{array}$ & 4300 \\
\hline & 1.6 & 70 & 0.04 & $\begin{array}{l}600(\text { at } 0.7 \\
\text { V) }\end{array}$ & $\mathrm{N} / \mathrm{A}$ \\
\hline & 1.6 & 40 & $\mathrm{~N} / \mathrm{A}$ & $\begin{array}{l}410(\text { at } 0.7 \\
\text { V) }\end{array}$ & 4300 \\
\hline $\begin{array}{l}\text { Sulfonated poly (4-phenoxybenzoyl1,4- } \\
\text { phenylene) [91] }\end{array}$ & 2.0 & $25-50$ & 0.01 & $\mathrm{~N} / \mathrm{A}$ & 200 \\
\hline $\begin{array}{l}\text { poly(oxa-p-phenylene-3,3-phthalido-p- } \\
\text { phenylene-oxa-pphenylene- oxy-p- } \\
\text { phenylene) S-PEEK-WC [92] }\end{array}$ & 0.76 & 40 & 0.017 & 606 & $\mathrm{~N} / \mathrm{A}$ \\
\hline $\begin{array}{l}\text { Sulfonamide functionalized Poly } \\
\text { phosphazenes [93] }\end{array}$ & 0.99 & 100 & $0.06\left(80^{\circ} \mathrm{C}\right)$ & $\begin{array}{l}220(\text { at } 0.7 \\
\text { V) }\end{array}$ & $\mathrm{N} / \mathrm{A}$ \\
\hline \multicolumn{6}{|l|}{ Polymer Blends } \\
\hline $\begin{array}{l}\text { Sulfonated PEEK- aminated polysulfone } \\
\text { blend [94] }\end{array}$ & 1.58 & 29 & 0.03 & $\begin{array}{l}600(\text { at } 0.7 \\
\text { V) }\end{array}$ & $\mathrm{N} / \mathrm{A}$ \\
\hline $\begin{array}{l}\text { Sulfonated PEEK- poly benzimidazole } \\
\text { blend [94] }\end{array}$ & 1.26 & 37 & 0.03 & $\begin{array}{l}400(\text { at } 0.7 \\
\text { V) }\end{array}$ & $\mathrm{N} / \mathrm{A}$ \\
\hline $\begin{array}{l}\text { Phosphoric acid-doped sulfonated } \\
\text { polysulfone [95] }\end{array}$ & 0.81 & $80-110$ & $0.02-0.2$ & $\begin{array}{l}50-150(\text { at } \\
0.7 \mathrm{~V})\end{array}$ & $\mathrm{N} / \mathrm{A}$ \\
\hline PES- poly benzimidazole blend [279] & $\mathrm{N} / \mathrm{A}$ & 70 & $0.072\left(25^{\circ} \mathrm{C}\right)$ & $\begin{array}{l}800(\text { at } 0.541 \\
\text { V) }\end{array}$ & $\mathrm{N} / \mathrm{A}$ \\
\hline
\end{tabular}

\subsubsection{Polymer blends}

Polymer blend technology might represent a more versatile approach for the development of new membrane materials, where the material properties of blends can be varied over a wide 
range. Relative to a single-component polymeric material, a blend enjoys several degrees of freedom that allow tailoring of the material to meet the membrane requirements. The obvious source of flexibility is the presence of two materials that can have quite different properties, e.g., good mechanical properties and good proton transport.

Polymer blend membranes have been synthesized by combining polymeric nitrogencontaining bases ( $\mathrm{N}$ bases) with polymeric sulfonic acids. The sulfonic acid groups interact with the N-base either to form hydrogen bonds or by protonating the basic N-sites [96, 97]. The most advanced acid-base polymer blends are those based on sulfonated poly (etheretherketone) (S-PEEK) or ortho-sulfonesulfonated poly (ethersulfone) (SPSU) as the acidic component, and poly (benzimidazole) (PBI) as the basic component. SPEEK based blends are explored to obtain good mechanical properties, high proton conductivity, and optimized membrane properties. These membranes show excellent thermal stabilities (decomposition temperatures ranging between 270 and $350^{\circ} \mathrm{C}$ ) and good proton conductivities. Their performance in direct hydrogen fuel cells at $70^{\circ} \mathrm{C}$ is similar to that of Nafion 112, however, only limited durability has been demonstrated. In addition to direct hydrogen testing, preliminary studies in DMFCs have shown their suitability for this application and it is reported that their methanol permeability is significantly lower than that of Nafion [98]. Quantitatively, the methanol crossover rate is reduced by a factor of about 8 and 15, respectively, for S-PSU/PBI and S-PEEK/PBI membranes.

\section{$3 \quad$ Electro-catalysts for PEMFC}

Platinum is considered as the best catalyst for both anode and cathode fuel cell reactions despite a large difference between the ORR and the hydrogen oxidation reaction (HOR). The oxygen reduction reaction (ORR) at the cathode is a sluggish and complicated two/four electron reaction $[100,101]$. However, even on pure $\mathrm{Pt}$, the overpotential for ORR is in excess of $300 \mathrm{mV}$. A great deal of effort has been made by many researchers toward developing appropriate catalyst materials, especially for the ORR. On the anode catalyst, most of the studies have focused on addressing the CO poisoning issues of the Pt catalyst. In the subsequent sections we will discuss in detail on the anode and cathode catalysts, with more emphasis on ORR catalysts.

\subsection{Anode catalyst}

Platinum is an excellent catalyst for the hydrogen oxidation reaction and has a very high exchange current density but is susceptible for CO poisoning. Unfortunately, for many practical applications, the presence of trace levels of carbon monoxide (CO) impurities in the hydrogen-rich gas mixture produced by reforming of hydrocarbon fuels is inevitable. CO can strongly adsorb on the Pt catalyst and even mere traces (10 ppm) blocks the catalytically active area, thereby significantly decreasing its reactivity. This is termed as "CO poisoning" of the catalysts. The search for CO-tolerant catalysts has been a challenging task in the successful development of more efficient PEMFC systems [102, 103]. 


\subsubsection{CO tolerant catalysts}

The development of an anode catalyst with significantly lower affinity for carbon monoxide, either under steady state operation or under conditions of high CO transient content is the challenge for low temperature PEMFC systems. Platinum-ruthenium catalysts appear to tolerate $\mathrm{CO}$ better than platinum catalysts and an increase in cell temperature improves tolerance. $\mathrm{CO}$ tolerant catalyst research, as from its name, is based on improving the $\mathrm{CO}$ tolerance of Platinum catalysts by incorporating secondary metals, which might either reduce the Pt-CO bond strength or to supply hydroxyl ions easily to the Pt surface and aid oxidation of $\mathrm{CO}$.

In this context, several approaches have been attempted to reduce the CO poisoning [104106]. A number of platinum alloys or mixtures of platinum with a noble or non-noble constituent have been proposed to address the $\mathrm{CO}$ poisoning issues, such as $\mathrm{Pt}-\mathrm{Ru}[107$ 110], Pt-Sn [111] Pt-Fe [112], Pt-Mo [113], Pt-Co [114], Pt-Ni [115] and Pt-W [112] and Pt$\mathrm{WO}_{3}$ [117]. The high $\mathrm{CO}$ tolerance of these materials is usually explained by two distinct mechanisms: the so-called bi-functional and electronic mechanisms. In the first, the presence of a second metal promotes the electro-oxidation of $\mathrm{CO}$ to $\mathrm{CO}_{2}$ after a spillover process of the $\mathrm{OH}$-species formed on the oxophilic sites of the second metal to the Pt-CO [119]. On the other hand, the electronic effect $[120,121]$ postulates that the presence of the second metal modifies the $\mathrm{Pt}$ properties for the $\mathrm{H}_{2}$ and $\mathrm{CO}$ chemisorptions, reducing the $\mathrm{CO}$ coverage and leaving more free Pt sites available for the $\mathrm{H}_{2}$ oxidation.

Pt-Ru has shown promising performance for HOR in the presence of CO [122] and is one of the most extensively studied anode catalyst, but the origin of this effect (bifunctional or electronic) remains an open question. In this direction, one of the most widely discussed topics is the question of whether alloy formation in the binary $\mathrm{Pt}-\mathrm{Ru}$ system is a prerequisite for a better electro-catalytic activity when in the presence of CO [123-125]. Some of the results even appear to be in contrast to the structures required for a bifunctional mechanism or electronic modifications, which involves intermixing and intimate contact between Pt and $\mathrm{Ru}$.

Okada et al. have reported that $\mathrm{Pt}-\mathrm{VO}$ (salen)/C and $\mathrm{Pt}-\mathrm{Ni}$ (mqph)/C proved very promising performances and very high $\mathrm{CO}$ tolerances when compared with $\mathrm{Pt} / \mathrm{C}$ and $\mathrm{Pt}-\mathrm{Ru} / \mathrm{C}$ alloy catalysts $[114,115]$. It is expected that the $\mathrm{Ni}$ in the complex interacts with $\mathrm{CO}$ and the complex oxidizes CO due to the negative potential of anode where the HOR occurs. It is assumed that the catalytic activity of $\mathrm{Pt}-\mathrm{VO}($ salen $) / \mathrm{C}$ links to the higher valence states of vanadium. When $\mathrm{CO}$ molecule coordinates to the central metal of chelate in a higher oxidation state, $\mathrm{CO}$ is activated resulting in a reduced back donation from the metal, which in turn induces a nucleophilic attack by $\mathrm{H}_{2} \mathrm{O}$. Another mechanism reported is that the organic complexes may provide $\mathrm{CO}$ spillover sites near the platinum particle and increase the mobility of $\mathrm{CO}$ so that free active sites are available for HOR on Pt 
Another promising material is based on Pt-Fe. Pt-Fe exhibit excellent $\mathrm{CO}$ tolerance for the HOR, similar to that of the Pt-Ru alloy. The CO tolerance is due to a positive shift in the binding energy of the $\mathrm{Pt} 4 \mathrm{f}$ or $4 \mathrm{~d}$ orbitals. The positive shift of the binding energies indicates an increased d-vacancy at the valence band ( $5 \mathrm{~d}$ orbital), resulting in a lower electron backdonation to the CO molecules and thereby reducing the CO coverage [126]. CO tolerance of PdPt catalysts was examined and reported as exhibiting enhanced CO tolerance compared to Pt [118].

Since the electronic density states of tungsten carbides (near Fermi level) resembles that of noble metal, platinum tungsten carbides might have many of the desired catalytic properties with respect to HOR $[127,128]$. Pt supported on mesoporous tungsten carbide (WC-phase) might serve as an effective $\mathrm{CO}$ tolerant electro-catalyst for hydrogen than a commercial $\mathrm{Pt} / \mathrm{C}$ catalyst [129]. $\mathrm{Pt} / \mathrm{WO}_{3}-\mathrm{C}, \mathrm{Pt}-\mathrm{Ru} / \mathrm{WO}_{3}$ and $\mathrm{Pt}-\mathrm{Ru}-\mathrm{W}_{2} \mathrm{C}$ show improved activity in a CO containing $\mathrm{H}_{2}$ stream [130-132].

Ternary Pt-based catalysts have also been investigated in which an additional oxophilic component such as $\mathrm{Sn}, \mathrm{Ir}, \mathrm{Rh}, \mathrm{Os}, \mathrm{Mo}, \mathrm{W}, \mathrm{WO}_{3}$ or Re is added to Pt-Ru to promote CO oxidation at lower potentials [116,133,]. Some studies on ternary catalysts without Ru has also been reported, for example $\mathrm{Au}$ and Fe additives to Pt was reported to enhance the COtolerant HOR activity as compared to Pt alone [134]. The summary of the CO tolerant anodes is given in Table 5 .

In addition, efforts to develop Pt-free electrocatalysts such as $\mathrm{PdAu} / \mathrm{C}$ have been undertaken [137] but only few studies are reported so far. The study on molybdenumtungsten carbide (MoWC) revealed that increase in the catalytic performance was dependant on the catalyst dispersion on carbon and activation by a water vapor treatment. The performance of nickel-tungsten carbides (NiWC) and cobalt-molybdenum carbides (CoMoC) were reported to be about $10 \%$ of that of a $\mathrm{Pt} / \mathrm{C}$ catalyst in a single cell fuel cell $[138,139]$. Critical reviews on this topic have been published by some groups [140-142].

Table 5: Summary of data on CO tolerant anodes.

\begin{tabular}{|c|c|c|c|c|c|}
\hline Catalyst & $\begin{array}{l}\text { Preparation } \\
\text { method }\end{array}$ & $\begin{array}{l}\text { Specific } \\
\text { Activity } \\
\left(\mathrm{mAcm}^{-2}\right)\end{array}$ & $\begin{array}{l}\text { Mass } \\
\text { specific } \\
\text { activity } \\
(\mathrm{mA} / \mathrm{mg})\end{array}$ & $\begin{array}{l}\text { Measurement } \\
\text { conditions }\end{array}$ & Comments \\
\hline $20 \% \mathrm{Pt} / \mathrm{C}$ (E-Tek) [129] & $\mathrm{N} / \mathrm{A}$ & $\begin{array}{l}28.3(0.0 \\
V)\end{array}$ & $71(0.0 \mathrm{~V})$ & $\begin{array}{l}1 \mathrm{M} \mathrm{H}_{2} \mathrm{SO}_{4} \\
\text { (without } 1 \% \\
\mathrm{CO} \text { ) }\end{array}$ & $\mathrm{N} / \mathrm{A}$ \\
\hline $20 \% \mathrm{Pt} / \mathrm{C}$ (E-Tek) [129] & $\mathrm{N} / \mathrm{A}$ & $\begin{array}{l}28.3(0.0 \\
V)\end{array}$ & $59(0.0 \mathrm{~V})$ & $\begin{array}{l}1 \mathrm{M} \mathrm{H}_{2} \mathrm{SO}_{4} \\
\text { with } 1 \% \mathrm{CO} \\
\text { and } 99 \% \mathrm{H}_{2}\end{array}$ & $\mathrm{~N} / \mathrm{A}$ \\
\hline $7.5 \% \mathrm{Pt} / \mathrm{WC}[129]$ & Borohydride & $20.5(0.0$ & $136(0.0$ & $1 \mathrm{M} \mathrm{H}_{2} \mathrm{SO}_{4}$ & $\mathrm{~N} / \mathrm{A}$ \\
\hline
\end{tabular}

Page $\mid 20$ 


\begin{tabular}{|c|c|c|c|c|c|}
\hline & reduction & V) & V) & $\begin{array}{l}\text { (without 1\% } \\
\text { CO) }\end{array}$ & \\
\hline $7.5 \% \mathrm{Pt} / \mathrm{WC}[129]$ & $\begin{array}{l}\text { Borohydride } \\
\text { reduction }\end{array}$ & $\begin{array}{l}19.3(0.0 \\
\text { V) }\end{array}$ & $\begin{array}{l}128(0.0 \\
V)\end{array}$ & $\begin{array}{l}1 \mathrm{M} \mathrm{H}_{2} \mathrm{SO}_{4} \\
\text { with } 1 \% \mathrm{CO} \\
\text { and } 99 \% \mathrm{H}_{2}\end{array}$ & $\begin{array}{l}\mathrm{Pt} / \mathrm{WC} \text { shows } \\
\text { higher } \mathrm{CO} \\
\text { tolerance than } \\
\mathrm{Pt} / \mathrm{C}\end{array}$ \\
\hline Pt-WO $x / C[130]$ & Impregnation & $\mathrm{N} / \mathrm{A}$ & $\mathrm{N} / \mathrm{A}$ & $\begin{array}{l}\mathrm{H}_{2}+100 \mathrm{ppm} \\
\mathrm{CO}\end{array}$ & $\begin{array}{l}\text { Comparable } \\
\text { CO-tolerance } \\
\text { than } 20 \mathrm{wt} \% \\
\mathrm{Pt}-\mathrm{Ru} / \mathrm{C} \text { at } \\
\text { short times (t } \\
<3000 \mathrm{~s})\end{array}$ \\
\hline $\begin{array}{l}\text { Pt- } \\
\text { Rucolloid, } \mathrm{Pt}_{0.5} \mathrm{Ru}_{0.5} \mathrm{~N}(\mathrm{oct})_{4} \mathrm{Cl} / \mathrm{C} \\
{[110]}\end{array}$ & Colloid & $\mathrm{N} / \mathrm{A}$ & $\mathrm{N} / \mathrm{A}$ & $\begin{array}{l}\mathrm{H}_{2}+100 \mathrm{ppm} \\
\mathrm{CO}\end{array}$ & $\begin{array}{l}\text { Better } \\
\text { performance } \\
\text { than } \mathrm{Pt}-\mathrm{Ru} / \mathrm{C}\end{array}$ \\
\hline $\begin{array}{l}\mathrm{Pt}_{0.5} \mathrm{Ru}_{0.5} \mathrm{~N}(\mathrm{oct})_{4} \mathrm{Cl} / \mathrm{HOPG} \\
{[110]}\end{array}$ & Colloid & $\mathrm{N} / \mathrm{A}$ & $\mathrm{N} / \mathrm{A}$ & $\begin{array}{l}\mathrm{H}_{2}+100 \mathrm{ppm} \\
\mathrm{CO}\end{array}$ & $\begin{array}{l}\text { Better } \\
\text { performance } \\
\text { than } \mathrm{Pt}-\mathrm{Ru} / \mathrm{C}\end{array}$ \\
\hline Pt-Ru [116] & Impregnation & $\mathrm{N} / \mathrm{A}$ & $\mathrm{N} / \mathrm{A}$ & $\begin{array}{l}\mathrm{H}_{2}+150 \mathrm{ppm} \\
\mathrm{CO}\end{array}$ & $\begin{array}{l}\text { Better } \\
\text { performance } \\
\text { thanPt-W and } \\
\text { Pt-Mo }\end{array}$ \\
\hline Pt-Ru/CNT [108] & Impregnation & $\mathrm{N} / \mathrm{A}$ & $\mathrm{N} / \mathrm{A}$ & $\begin{array}{l}\mathrm{H} 2+100 \mathrm{ppm} \\
\text { of } \mathrm{CO}\end{array}$ & $\begin{array}{l}\text { Performance } \\
\text { similar to that } \\
\text { of PtRu/C }\end{array}$ \\
\hline Pt-VO(salen)/C $\mathrm{C}^{\mathrm{b}}[114]$ & $\begin{array}{l}\text { Organic metal } \\
\text { complex }\end{array}$ & $\mathrm{N} / \mathrm{A}$ & $\begin{array}{l}4770( \\
0.1 \mathrm{~V})\end{array}$ & $\begin{array}{l}\text { Half-cell at } 70 \\
{ }^{\circ} \mathrm{C} \text { - Pure } \mathrm{H}_{2}\end{array}$ & $\begin{array}{l}\text { Better CO- } \\
\text { tolerance than } \\
20 \mathrm{wt} \% \\
\mathrm{Pt}-\mathrm{Ru} / \mathrm{C}\end{array}$ \\
\hline Pt-VO(salen)/C $\mathrm{C}^{\mathrm{b}}[114]$ & $\begin{array}{l}\text { Organic metal } \\
\text { complex }\end{array}$ & $\mathrm{N} / \mathrm{A}$ & $\begin{array}{l}1974( \\
0.1 \mathrm{~V})\end{array}$ & $\begin{array}{l}\text { Half-cell at } 70 \\
{ }^{\circ} \mathrm{C}- \\
100 \mathrm{ppmCO} / \mathrm{H}_{2}\end{array}$ & $\begin{array}{l}\text { Better CO- } \\
\text { tolerance than } \\
20 \mathrm{wt} \% \\
\mathrm{Pt}-\mathrm{Ru} / \mathrm{C}\end{array}$ \\
\hline $\begin{array}{l}20 \mathrm{wt}^{\circ} \% \mathrm{Pt}-\mathrm{Ni}(\mathrm{mqph}) / \text { defect- } \\
\text { free } \mathrm{CNTs}^{\mathrm{c}}[115]\end{array}$ & $\begin{array}{l}\text { Organic metal } \\
\text { complex }\end{array}$ & $\mathrm{N} / \mathrm{A}$ & $\begin{array}{l}4230( \\
0.1 \mathrm{~V})\end{array}$ & $\begin{array}{l}\text { Half-cell at } 70 \\
{ }^{\circ} \mathrm{C} \text { - Pure } \mathrm{H}_{2}\end{array}$ & $\begin{array}{l}\text { High CO- } \\
\text { tolerance than } \\
20 \mathrm{wt} \% \\
\mathrm{Pt}-\mathrm{Ru} / \mathrm{C}\end{array}$ \\
\hline $\begin{array}{l}20 \mathrm{wt} . \% \mathrm{Pt}-\mathrm{Ni}(\mathrm{mqph}) / \text { defect- } \\
\text { free } \mathrm{CNTs}^{\mathrm{c}}[115]\end{array}$ & $\begin{array}{l}\text { Organic metal } \\
\text { complex }\end{array}$ & $\mathrm{N} / \mathrm{A}$ & $\begin{array}{l}3170( \\
0.1 \mathrm{~V})\end{array}$ & $\begin{array}{l}\text { Half-cell at } 70 \\
{ }^{\circ} \mathrm{C}- \\
100 \mathrm{ppmCO} / \mathrm{H}_{2}\end{array}$ & $\begin{array}{l}\text { High CO- } \\
\text { tolerance than } \\
20 \mathrm{wt} \% \\
\mathrm{Pt}-\mathrm{Ru} / \mathrm{C}\end{array}$ \\
\hline $\begin{array}{l}20 \text { wt. } \% \mathrm{Pt}- \\
\mathrm{Ni}(\mathrm{mqph}) / \text { defectiveCNTs }^{\mathrm{c}} \\
{[115]}\end{array}$ & $\begin{array}{l}\text { Organic metal } \\
\text { complex }\end{array}$ & $\mathrm{N} / \mathrm{A}$ & $\begin{array}{l}2720( \\
0.1 \mathrm{~V})\end{array}$ & $\begin{array}{l}\text { Half-cell at } 70 \\
{ }^{\circ} \mathrm{C} \text { - Pure } \mathrm{H}_{2}\end{array}$ & $\begin{array}{l}\text { Better CO- } \\
\text { tolerance than } \\
20 \mathrm{wt}^{\%} \% \\
\mathrm{Pt}-\mathrm{Ru} / \mathrm{C}\end{array}$ \\
\hline
\end{tabular}




\begin{tabular}{|c|c|c|c|c|c|}
\hline $\begin{array}{l}20 \mathrm{wt} . \% \mathrm{Pt}- \\
\mathrm{Ni}(\mathrm{mqph}) / \text { defectiveCNTs } \\
{[115]}\end{array}$ & $\begin{array}{l}\text { Organic metal } \\
\text { complex }\end{array}$ & $\mathrm{N} / \mathrm{A}$ & $820(0.1 \mathrm{~V})$ & $\begin{array}{l}\text { Half-cell at } 70 \\
{ }^{\circ} \mathrm{C}- \\
100 \mathrm{ppmCO} / \mathrm{H}_{2}\end{array}$ & $\begin{array}{l}\text { Better CO- } \\
\text { tolerance than } \\
20 \mathrm{wt} \% \\
\mathrm{Pt}-\mathrm{Ru} / \mathrm{C}\end{array}$ \\
\hline $\begin{array}{l}20 \text { wt.\%Pt- } \\
\text { Ni(mqph)/VulcanXC-72R[115] }\end{array}$ & $\begin{array}{l}\text { Organic metal } \\
\text { complex }\end{array}$ & $\mathrm{N} / \mathrm{A}$ & $\begin{array}{l}4480( \\
0.1 \mathrm{~V})\end{array}$ & $\begin{array}{l}\text { Half-cell at } 70 \\
\circ \mathrm{C} \text { - Pure } \mathrm{H}_{2}\end{array}$ & $\begin{array}{l}\text { Better CO- } \\
\text { tolerance than } \\
20 \mathrm{wt}^{\circ} \% \\
\mathrm{Pt}-\mathrm{Ru} / \mathrm{C}\end{array}$ \\
\hline $\begin{array}{l}20 \text { wt.\%Pt- } \\
\text { Ni(mqph)/VulcanXC-72R[115] }\end{array}$ & $\begin{array}{l}\text { Organic metal } \\
\text { complex }\end{array}$ & $\mathrm{N} / \mathrm{A}$ & $\begin{array}{l}2120( \\
0.1 \mathrm{~V})\end{array}$ & $\begin{array}{l}\text { Half-cell at } 70 \\
{ }^{\circ} \mathrm{C}- \\
100 \mathrm{ppmCO} / \mathrm{H}_{2}\end{array}$ & $\begin{array}{l}\text { Better CO- } \\
\text { tolerance than } \\
20 \mathrm{wt}^{\%} \% \\
\mathrm{Pt}-\mathrm{Ru} / \mathrm{C}\end{array}$ \\
\hline $\begin{array}{l}\text { commercial 20\%Pt- } \\
10 \% \mathrm{Ru} / \text { VulcanXC- } \\
\text { 72R (ElectroChem. Inc.)[115] }\end{array}$ & $\mathrm{N} / \mathrm{A}$ & $\mathrm{N} / \mathrm{A}$ & $\begin{array}{l}3440( \\
0.1 \mathrm{~V})\end{array}$ & $\begin{array}{l}\text { Half-cell at } 70 \\
{ }^{\circ} \mathrm{C} \text { - Pure } \mathrm{H}_{2}\end{array}$ & $\mathrm{~N} / \mathrm{A}$ \\
\hline $\begin{array}{l}\text { commercial } 20 \% \text { Pt- } \\
10 \% \text { Ru/VulcanXC- } \\
\text { 72R (ElectroChem. Inc.)[115] }\end{array}$ & $\mathrm{N} / \mathrm{A}$ & $\mathrm{N} / \mathrm{A}$ & $880(0.1 \mathrm{~V})$ & $\begin{array}{l}\text { Half-cell at } 70 \\
\circ \mathrm{C}- \\
100 \mathrm{ppmCO} / \mathrm{H}_{2}\end{array}$ & $\mathrm{~N} / \mathrm{A}$ \\
\hline $\mathrm{PtSn} / \mathrm{C}[111]$ & $\begin{array}{l}\text { Surface } \\
\text { organometallic } \\
\text { chemistry }\end{array}$ & $\mathrm{N} / \mathrm{A}$ & $\mathrm{N} / \mathrm{A}$ & $\begin{array}{l}\mathrm{H}_{2}+100 \mathrm{ppm} \\
\mathrm{CO}\end{array}$ & $\begin{array}{l}\text { Enhanced } \\
\text { activity with a } \\
\text { larger } \\
\text { decrease in } \\
\text { the onset } \\
\text { potential of } \\
\mathrm{CO} \text { oxidation } \\
\text { compared } \\
\text { with } \mathrm{Pt} / \mathrm{C}\end{array}$ \\
\hline PtMo [113] & $\begin{array}{l}\text { Chemical co } \\
\text { reduction }\end{array}$ & $\mathrm{N} / \mathrm{A}$ & $\mathrm{N} / \mathrm{A}$ & $\begin{array}{l}0.5 \mathrm{M} \\
\mathrm{H} 2 \mathrm{SO} 4,1000 \\
\text { ppm of } \mathrm{CO}\end{array}$ & $\begin{array}{l}\mathrm{Pt}_{0.8} \mathrm{Mo}_{0.2} \text { alloy } \\
\text { starts at a } \\
\text { higher } \\
\text { potential than } \\
\text { the } \\
\mathrm{MoO} \times \mathrm{Pt} \\
\text { catalysts }\end{array}$ \\
\hline MoOx@Pt Core-Shell [113] & $\begin{array}{l}\text { Sequential } \\
\text { chemical } \\
\text { reduction }\end{array}$ & $\mathrm{N} / \mathrm{A}$ & $\mathrm{N} / \mathrm{A}$ & $\begin{array}{l}0.5 \mathrm{M} \\
\mathrm{H} 2 \mathrm{SO} 4,1000 \\
\text { ppm of } \mathrm{CO}\end{array}$ & $\begin{array}{l}\text { MoOx@Pt } \\
\text { catalysts } \\
\text { shows } \\
\text { superior CO } \\
\text { tolerance } \\
\text { compared } \\
\text { to Pt and } \\
\text { PtRu catalysts }\end{array}$ \\
\hline Pt-W [116] & Impregnation & $\mathrm{N} / \mathrm{A}$ & $\mathrm{N} / \mathrm{A}$ & $\begin{array}{l}\mathrm{H}_{2}+150 \mathrm{ppm} \\
\mathrm{CO}\end{array}$ & $\begin{array}{l}\text { Less } \\
\text { performance } \\
\text { than Pt-Ru }\end{array}$ \\
\hline $\mathrm{Pt}-\mathrm{WO} x / \mathrm{C}[117]$ & Impregnation & $\mathrm{N} / \mathrm{A}$ & $\mathrm{N} / \mathrm{A}$ & $\begin{array}{l}\text { CO saturated } \\
1 \mathrm{M} \mathrm{H}_{2} \mathrm{SO}_{4}\end{array}$ & $\begin{array}{l}\text { Better CO- } \\
\text { tolerance for }\end{array}$ \\
\hline
\end{tabular}




\begin{tabular}{|c|c|c|c|c|c|}
\hline & & & & electrolyte & $\begin{array}{l}\mathrm{Pt}-\mathrm{WO} x / \mathrm{C} \\
\text { than } \mathrm{Pt}-\mathrm{Ru} / \mathrm{C}\end{array}$ \\
\hline $\mathrm{PdAu} / \mathrm{C}[137]$ & $\begin{array}{l}\text { Deposition of } \\
\text { bimetallic } \\
\text { colloidal } \\
\text { precursors }\end{array}$ & $\mathrm{N} / \mathrm{A}$ & $\mathrm{N} / \mathrm{A}$ & $\begin{array}{l}1000 \mathrm{ppm} \\
\mathrm{CO}: \mathrm{H} 260^{\circ} \mathrm{C}, \\
2500 \mathrm{rpm}, 0.5 \\
\text { M H2SO4 }\end{array}$ & $\begin{array}{l}\mathrm{PdAu} / \mathrm{C} \\
\text { seems to be } \\
\text { more } \mathrm{CO} \\
\text { tolerant than } \\
\mathrm{PtRu} / \mathrm{C} \text { at } 60 \\
{ }^{\circ} \mathrm{C}\end{array}$ \\
\hline $\mathrm{Pd}_{60} \mathrm{Pt}_{40} / \mathrm{C}$ [118] & $\begin{array}{l}\text { Formic acid } \\
\text { reduction }\end{array}$ & $\mathrm{N} / \mathrm{A}$ & $\mathrm{N} / \mathrm{A}$ & $\begin{array}{l}\text { PEMFC at } 85 \\
{ }^{\circ} \mathrm{C}, \text { fed with } \mathrm{H}_{2} \\
+100 \mathrm{ppm} \mathrm{CO}\end{array}$ & $\begin{array}{l}\mathrm{PdPt} / \mathrm{C} \text { and } \\
\mathrm{PdPtRu} / \mathrm{C} \\
\text { shows similar } \\
\text { performance }\end{array}$ \\
\hline Pd-Pt-Ru /C [118] & $\begin{array}{l}\text { Formic acid } \\
\text { reduction } \\
\text { method }\end{array}$ & $\mathrm{N} / \mathrm{A}$ & $\mathrm{N} / \mathrm{A}$ & $\begin{array}{l}\text { PEMFC at } 85 \\
{ }^{\circ} \mathrm{C}, \text { fed with } \mathrm{H}_{2} \\
+100 \mathrm{ppm} \mathrm{CO}\end{array}$ & $\begin{array}{l}\text { Higher CO } \\
\text { tolerance than } \\
\mathrm{Pt} / \mathrm{C}\end{array}$ \\
\hline Pt-Ru-Sn [116] & $\begin{array}{l}\text { Boennemann's } \\
\text { method }\end{array}$ & $\mathrm{N} / \mathrm{A}$ & $\mathrm{N} / \mathrm{A}$ & $\begin{array}{l}\mathrm{H} 2 / 150 \mathrm{ppm} \\
\mathrm{CO}\end{array}$ & $\begin{array}{l}\text { Exhibits } \\
\text { higher } \\
\text { performance } \\
\text { at higher } \\
\text { current } \\
\text { densities }\end{array}$ \\
\hline Pt-Ru-Mo [116] & $\begin{array}{l}\text { Boennemann's } \\
\text { method }\end{array}$ & $\mathrm{N} / \mathrm{A}$ & $\mathrm{N} / \mathrm{A}$ & $\begin{array}{l}\mathrm{H} 2 / 150 \mathrm{ppm} \\
\mathrm{CO}\end{array}$ & $\begin{array}{l}\text { Nearly same } \\
\text { performance } \\
\text { as ETEK } \\
\text { Pt/Ru } \\
\text { catalyst. }\end{array}$ \\
\hline Pt-Ru-W/C [116] & $\begin{array}{l}\text { Boennemann's } \\
\text { method }\end{array}$ & $\mathrm{N} / \mathrm{A}$ & $\mathrm{N} / \mathrm{A}$ & $\begin{array}{l}\mathrm{H} 2 / 150 \mathrm{ppm} \\
\mathrm{CO}\end{array}$ & $\begin{array}{l}\mathrm{Pt} / \mathrm{Ru} / \mathrm{W} \text { is } \\
\text { the most } \\
\text { active } \\
\text { than E-TEK } \\
\mathrm{Pt} / \mathrm{Ru} \text { catalyst }\end{array}$ \\
\hline PtRuIr/C [133] & $\begin{array}{l}\text { Microwave- } \\
\text { irradiated } \\
\text { polyol plus } \\
\text { annealing }\end{array}$ & $\mathrm{N} / \mathrm{A}$ & $\mathrm{N} / \mathrm{A}$ & $\begin{array}{l}\mathrm{H}_{2} / 100 \mathrm{ppm} \\
\mathrm{CO}\end{array}$ & $\begin{array}{l}\text { Enhanced } \\
\text { activity for } \\
\text { COads } \\
\text { electro- } \\
\text { oxidation,even } \\
\text { higher than } \\
\text { that of the E- } \\
\text { TEK PtRu/C } \\
\text { catalyst. }\end{array}$ \\
\hline $\mathrm{Pt}-\mathrm{Ru}-\mathrm{Co} / \mathrm{C}$ [134] & $\begin{array}{l}\text { Urea } \\
\text { combustion } \\
\text { synthesis }\end{array}$ & $\mathrm{N} / \mathrm{A}$ & $\mathrm{N} / \mathrm{A}$ & $\mathrm{N} / \mathrm{A}$ & $\begin{array}{l}\text { Similar } \\
\text { performance } \\
\text { to } \mathrm{Pt}-\mathrm{Ru} / \mathrm{C}\end{array}$ \\
\hline PtAuFe/C [135] & $\begin{array}{l}\text { Microwave } \\
\text { irradiated } \\
\text { polyol process }\end{array}$ & $\begin{array}{l}200(0.803 \\
\text { V })^{d}\end{array}$ & $\mathrm{~N} / \mathrm{A}$ & $\begin{array}{l}\text { single cell tests, } \\
\text { pure } \\
\mathrm{H}_{2} \text { and } 100 \\
\text { ppm CO }\end{array}$ & $\begin{array}{l}\text { High CO- } \\
\text { tolerant } \\
\text { performance } \\
\text { than } \mathrm{Pt} / \mathrm{C}\end{array}$ \\
\hline
\end{tabular}




\begin{tabular}{|c|c|c|c|c|c|}
\hline Pt-Ru-Mo [102] & Colloid & $\mathrm{N} / \mathrm{A}$ & $\mathrm{N} / \mathrm{A}$ & $\begin{array}{l}\mathrm{H}_{2}+100 \mathrm{ppm} \\
\mathrm{CO}\end{array}$ & $\mathrm{N} / \mathrm{A}$ \\
\hline Pt-Ru-W [102] & Colloid & $\mathrm{N} / \mathrm{A}$ & $\mathrm{N} / \mathrm{A}$ & $\begin{array}{l}\mathrm{H}_{2}+100 \mathrm{ppm} \\
\mathrm{CO}\end{array}$ & $\mathrm{N} / \mathrm{A}$ \\
\hline $\begin{array}{l}\mathrm{Pt}_{4} \mathrm{M} / \mathrm{C}_{1}(\mathrm{M}=\mathrm{Mo}, \mathrm{Nb} \& \mathrm{Ta}) \\
{[136]}\end{array}$ & Degussa & $\mathrm{N} / \mathrm{A}$ & $\mathrm{N} / \mathrm{A}$ & $\begin{array}{l}\mathrm{H}_{2}+100 \mathrm{ppm} \\
\mathrm{CO}\end{array}$ & $\begin{array}{l}\text { carbon } \\
\text { supported } \\
\text { PtMo } \\
\text { (4:1) exhibit } \\
\text { enhanced CO } \\
\text { tolerance } \\
\text { compared to } \\
\text { Pt/C } \\
\text { and the other } \\
\text { binary systems } \\
\text { tested, but do } \\
\text { not } \\
\text { outperform } \\
\text { PtRu/C. }\end{array}$ \\
\hline
\end{tabular}

a. Highly oriented pyrolytic graphite

b. salen: N,N-bis(salicylidene)ethylenediamine

c. mqph: N,N-mono-8-quinolyl-o-phenylenediamine.

d. Fuel cell performance

\subsection{Cathode catalyst}

The cathode accounts for about one third of the performance losses in a PEMFC, mainly due to the limitations of the ORR catalyst. The ORR is a challenging reaction to catalyze, in the sense that the catalyst material must be (i) stable under the extremely corrosive conditions at a PEMFC cathode, (ii) chemically active to be able to activate $\mathrm{O}_{2}$ and (iii) noble enough to be able to release the oxygen from the surface in the form of $\mathrm{H}_{2} \mathrm{O}$.

$\mathrm{O}_{2}$ activation typically involves the adsorption of $\mathrm{O}_{2}$ on the catalytically active sites through a proton and electron transfer to form adsorbed $\mathrm{OOH}$ before the $\mathrm{O}-\mathrm{O}$ bond is broken, hence the catalyst must be able to stabilize $\mathrm{OOH}$ moderately. After dissociation, adsorbed $\mathrm{O}$ and $\mathrm{OH}$ are formed on the catalyst surface, and the catalyst must not bind these species too strongly in order for $\mathrm{H}_{2} \mathrm{O}$ desorption to be fast $[143,144]$.

Both noble and non-noble metal based electrodes were studied for oxygen reduction, however, platinum seems to be the best single metal catalyst. In the case of noble metal catalysts, the activity of palladium based materials appears to close to that of platinum, whereas in the case of non-noble metal electrocatalysts, transition metal chalcogenides and pyrolysed macrocylcic compounds have been widely studied [144]. 


\subsubsection{ORR catalyzed by noble metal electrodes}

The most promising catalyst for ORR is platinum, since it exhibits good activity and stability under the operating conditions of the PEMFC. However, platinum is expensive and scarce and thereby the focus is to reduce the Pt loading or to find an alternative non noble metal catalyst. Efforts have been made to reduce Pt loading through (i) increasing the Pt catalytic activity be incorporating transition metals and (ii) improving the Pt utilization by increasing the surface area and dispersion of Pt nanoparticles using high surface area supports. Other approaches include developing Pt-free catalysts and non-noble metal catalysts for ORR. Table 6 shows some of the noble metal based catalysts studied for ORR.

Several Pt alloys, including late transition metals such as $\mathrm{Ni}, \mathrm{Co}, \mathrm{Cr}$ and $\mathrm{Fe}$, together with partially dealloyed core-shell catalysts derived from $\mathrm{Pt}-\mathrm{Cu}$ nanoparticles, are considerably more active than Pt and have been studied intensively [145-155]. The reasons for the higher catalytic activity of Pt based binary catalysts have been reported to be due to (i) an increase in the resistance to particle sintering, (ii) surface roughening due to removal of some base metal, increasing the Pt surface area (iii) preferred crystallographic orientation (iv) geometric factors (decreased Pt-Pt bond distance)[156], (v) dissolution of the more oxidisable alloying component[157], (vi) change in surface structure [158] or electronic factors (increased Pt dband electron vacancy of the Pt skin layer originating from the bulk alloys) (vii) oxygen adsorption differences due to modified anion and water adsorption $[159,160]$.

Combinatorial studies of a series of Pt-based bimetallic alloy thin film catalysts have revealed significant increase of activities for ORR with certain bimetallic catalysts (e.g. PtFe, PtNi, and $\mathrm{PtV}$ thin films). The introduction of a third metal to the alloy is expected to produce a combination of effects such as the reduction of the Pt-Pt lattice distance, the addition of surface sites for the formation of metal-oxygen bonds and adsorption of $\mathrm{OH}^{-}$, and the modification of the d-band center. Among the various carbon-supported trimetallic nanoparticle catalysts, $\mathrm{PtVFe} / \mathrm{C}$ and $\mathrm{PtNiFe} / \mathrm{C}$ alloy nanoparticle catalysts were shown to be highly active for ORR [175].

While great progress have been made in recent years, the Pt area-specific ORR activity is still far below the value that has been demonstrated for the $\mathrm{Pt}_{3} \mathrm{Ni}$ (111) single crystal surface, which is 90 times that of $\mathrm{Pt} / \mathrm{C}$ [146]. A 9-fold enhancement in area-specific activity has been achieved by changing from the (100) to the (111) $\mathrm{Pt}_{3} \mathrm{Ni}$ crystal surface. What is apparent from the table is that the order of ORR activity of the catalysts, Monometallic $<$ Bimetallic

$\leq$ Trimetallic, which indicates that the addition of additional metals to platinum has definitely a positive effect on its catalytic activity.

Table 6: Summary of data on Pt based cathodes. 


\begin{tabular}{|c|c|c|c|c|}
\hline Catalyst & $\begin{array}{c}\text { ECSA } \\
{\left[\mathrm{m}^{2} \mathrm{~g}^{-1}\right.} \\
\mathrm{Pt}]\end{array}$ & $\begin{array}{c}\text { Potential } \\
\text { for } \\
\text { measuring } \\
\text { MA/V } \\
\text { vs. RHE }\end{array}$ & $\begin{array}{c}\text { MA/ } \\
{\text { A } \mathrm{g}^{-1} \mathbf{P t}}^{-}\end{array}$ & $\begin{array}{l}\text { Measurement } \\
\text { conditions }\end{array}$ \\
\hline \multicolumn{5}{|l|}{ Monometallic } \\
\hline $\begin{array}{l}6.2-11.6 \% \text { Pt/HSAG } 300 \\
\text { graphite [161] }\end{array}$ & $\mathrm{N} / \mathrm{A}$ & $0.85 \mathrm{~V}$ & $20-25$ & $\begin{array}{l}\mathrm{O}_{2} \text { saturated } 0.1 \mathrm{M} \mathrm{H}_{2} \mathrm{SO}_{4}, \\
20^{\circ} \mathrm{C}\end{array}$ \\
\hline $20 \% \mathrm{Pt} / \mathrm{C}[162]$ & $\mathrm{N} / \mathrm{A}$ & $0.85 \mathrm{~V}$ & 289 & Nafion 117 \\
\hline $20 \% \mathrm{Pt} / \mathrm{C}[163]$ & $\mathrm{N} / \mathrm{A}$ & $0.85 \mathrm{~V}$ & 55.3 & $\mathrm{O}_{2}$ saturated $0.1 \mathrm{M} \mathrm{HClO}_{4}$ \\
\hline $30 \mathrm{wt} \% \mathrm{Pt} / \mathrm{C}[164]$ & 79 & $0.9 \mathrm{~V}$ & 160 & $\mathrm{O}_{2}$ saturated $0.1 \mathrm{M} \mathrm{HClO}_{4}$ \\
\hline $45 \mathrm{wt}_{0} \% \mathrm{Pt} / \mathrm{C}[164]$ & 62 & $0.9 \mathrm{~V}$ & 100 & $\mathrm{O}_{2}$ saturated $0.1 \mathrm{M} \mathrm{HClO}_{4}$ \\
\hline $\mathrm{Pt} / \mathrm{C}[171]$ & 65 & $0.9 \mathrm{~V}$ & 140 & $\begin{array}{l}\mathrm{O}_{2} \text { saturated } 0.1 \mathrm{M} \\
\mathrm{HClO}_{4}, \mathrm{RT}\end{array}$ \\
\hline $\mathrm{Pt} / \mathrm{C}[173]$ & $\mathrm{N} / \mathrm{A}$ & $0.9 \mathrm{~V}$ & 130 & $\mathrm{O}_{2}$ saturated Nafion 112 \\
\hline Commercial Pt/C[166] & $\mathrm{N} / \mathrm{A}$ & $0.9 \mathrm{~V}$ & $\overline{\mathrm{N} / \mathrm{A}}$ & $\mathrm{O}_{2}$ saturated $0.1 \mathrm{M} \mathrm{HClO}_{4}$ \\
\hline $\begin{array}{l}33 \% \text { Pt/ordered nanoporous } \\
\text { carbon [168] }\end{array}$ & $\mathrm{N} / \mathrm{A}$ & $0.9 \mathrm{~V}$ & 100 & $\begin{array}{l}\mathrm{O}_{2} \text { saturated } 0.1 \mathrm{M} \\
\mathrm{HClO}_{4}, \mathrm{RT}\end{array}$ \\
\hline $\mathrm{Pt} / \mathrm{CNx}[174]$ & 54.9 & MPCD & 126.7 & $\mathrm{O}_{2}$-saturated $0.5 \mathrm{M} \mathrm{H}_{2} \mathrm{SO}_{4}$ \\
\hline $\mathrm{Pt} / \mathrm{C}[174]$ & 49.5 & MPCD & 103.0 & $\mathrm{O}_{2}$-saturated $0.5 \mathrm{M} \mathrm{H}_{2} \mathrm{SO}_{4}$ \\
\hline Bare Pt nanocube [166] & $\mathrm{N} / \mathrm{A}$ & $0.9 \mathrm{~V}$ & 40 & $\mathrm{O}_{2}$ saturated $0.1 \mathrm{M} \mathrm{HClO}_{4}$ \\
\hline Pt nanotubes [172] & $\mathrm{N} / \mathrm{A}$ & $0.85 \mathrm{~V}$ & 80 & $\mathrm{O}_{2}$-saturated $0.5 \mathrm{M} \mathrm{H}_{2} \mathrm{SO}_{4}$ \\
\hline \multicolumn{5}{|l|}{ Bimetallic } \\
\hline $\mathrm{Pt}-\mathrm{Co} / \mathrm{C}[173]$ & $\mathrm{N} / \mathrm{A}$ & $0.9 \mathrm{~V}$ & 300 & Nafion 112 \\
\hline $\mathrm{Pt}_{25} \mathrm{CO}_{75} / \mathrm{C}[164]$ & 70 & $0.9 \mathrm{~V}$ & 340 & $\mathrm{O}_{2}$ saturated $0.1 \mathrm{M} \mathrm{HClO}_{4}$ \\
\hline $20 \%$ Pt-Co $(1: 7) / C$ [169] & $\mathrm{N} / \mathrm{A}$ & $0.77 \mathrm{~V}$ & 217 & $\begin{array}{l}\mathrm{O}_{2} \text { saturated } 0.5 \mathrm{M} \mathrm{H}_{2} \mathrm{SO}_{4} \text { at } \\
90^{\circ} \mathrm{C}\end{array}$ \\
\hline $\mathrm{Pt}_{3} \mathrm{Co} / \mathrm{CNx}[174]$ & 41.4 & MPCD & 303.4 & $\mathrm{O}_{2}$-saturated $0.5 \mathrm{M} \mathrm{H}_{2} \mathrm{SO}_{4}$ \\
\hline $\mathrm{Pt}_{3} \mathrm{Co}_{2} / \mathrm{CNx}[174]$ & 38.3 & MPCD & 222.8 & $\mathrm{O}_{2}$-saturated $0.5 \mathrm{M} \mathrm{H}_{2} \mathrm{SO}_{4}$ \\
\hline $\mathrm{PtCo} / \mathrm{CNx}[174]$ & 34.3 & MPCD & 216.3 & $\mathrm{O}_{2}$-saturated $0.5 \mathrm{M} \mathrm{H}_{2} \mathrm{SO}_{4}$ \\
\hline $\mathrm{Pt}_{3} \mathrm{Ni}[171]$ & 62.4 & $0.9 \mathrm{~V}$ & 530 & $\begin{array}{l}\mathrm{O}_{2} \text { saturated } 0.1 \mathrm{M} \mathrm{HClO}_{4}, \\
\text { RT }\end{array}$ \\
\hline Bare $\mathrm{Pt}_{3} \mathrm{Ni}$ nanoctahedra [166] & $\mathrm{N} / \mathrm{A}$ & $0.9 \mathrm{~V}$ & 280 & $\mathrm{O}_{2}$ saturated $0.1 \mathrm{M} \mathrm{HClO}_{4}$ \\
\hline Bare $\mathrm{Pt}_{3} \mathrm{Ni}[166]$ & $\mathrm{N} / \mathrm{A}$ & $0.9 \mathrm{~V}$ & 55 & $\mathrm{O}_{2}$ saturated $0.1 \mathrm{M} \mathrm{HClO}_{4}$ \\
\hline $\mathrm{Pt}_{3} \mathrm{Ni}$ nanoctahedra/C [166] & $\mathrm{N} / \mathrm{A}$ & $0.9 \mathrm{~V}$ & 300 & $\mathrm{O}_{2}$ saturated $0.1 \mathrm{M} \mathrm{HClO}_{4}$ \\
\hline $\mathrm{Pt}-\mathrm{Au} / \mathrm{C}[177]$ & $82.5^{a}$ & $0.75 \mathrm{~V}$ & $130^{a}$ & $\mathrm{O}_{2}$-saturated $0.5 \mathrm{M} \mathrm{H}_{2} \mathrm{SO}_{4}$ \\
\hline $\mathrm{Au}_{23} \mathrm{Pt}_{77} / \mathrm{C}(15 \% \mathrm{Pt})[175]$ & $\mathrm{N} / \mathrm{A}$ & $0.858 \mathrm{~V}$ & 420 & $\mathrm{O}_{2}$-saturated $0.5 \mathrm{M} \mathrm{H}_{2} \mathrm{SO}_{4}$ \\
\hline $14 \% \mathrm{Pt}_{20} \mathrm{Cu}_{80} / \mathrm{DMC}-2000$ [170] & 83 & $0.9 \mathrm{~V}$ & 450 & $\mathrm{O}_{2}$ saturated $0.1 \mathrm{M} \mathrm{HClO}_{4}$ \\
\hline Pd-Pt nanodendrites [165] & 57.1 & $0.9 \mathrm{~V}$ & $204^{a}$ & $\begin{array}{l}\mathrm{O}_{2} \text {-saturated } 0.1 \mathrm{M} \\
\mathrm{HClO}_{4} \mathrm{RT}\end{array}$ \\
\hline Pt-Pd nanotubes [172] & $\mathrm{N} / \mathrm{A}$ & $0.85 \mathrm{~V}$ & 120 & $\mathrm{O}_{2}$-saturated $0.5 \mathrm{M} \mathrm{H}_{2} \mathrm{SO}_{4}$ \\
\hline \multicolumn{5}{|l|}{ Trimetallic } \\
\hline $\mathrm{Pd}_{3} \mathrm{Fe} @ \mathrm{Pt} / \mathrm{C}[167]$ & 86.11 & $0.8 \mathrm{~V}$ & $5^{a}$ & $\mathrm{O}_{2}$-saturated $0.5 \mathrm{M} \mathrm{H}_{2} \mathrm{SO}_{4}$ \\
\hline $\mathrm{Pt}_{20} \mathrm{Cu}_{20} \mathrm{Co}_{60} / \mathrm{C}[164]$ & 111 & $0.9 \mathrm{~V}$ & 490 & $\mathrm{O}_{2}$ saturated $0.1 \mathrm{M} \mathrm{HClO}_{4}$ \\
\hline $\mathrm{Pd}_{45} \mathrm{Pt}_{5} \mathrm{Sn}_{50}[176]$ & $\mathrm{N} / \mathrm{A}$ & $\mathrm{N} / \mathrm{A}$ & $\mathrm{N} / \mathrm{A}$ & Nafion 115 \\
\hline $31 \% \mathrm{Pt}_{32} \mathrm{~V}_{14} \mathrm{Fe}_{54} / \mathrm{C}[175]$ & $\mathrm{N} / \mathrm{A}$ & $0.858 \mathrm{~V}$ & 380 & $\mathrm{O}_{2}$-saturated $0.5 \mathrm{M} \mathrm{H}_{2} \mathrm{SO}_{4}$ \\
\hline $30 \% \mathrm{Pt}_{31} \mathrm{Ni}_{34} \mathrm{Fe}_{35} / \mathrm{C}[175]$ & $\mathrm{N} / \mathrm{A}$ & $0.858 \mathrm{~V}$ & 480 & $\mathrm{O}_{2}$-saturated $0.5 \mathrm{M} \mathrm{H}_{2} \mathrm{SO}_{4}$ \\
\hline
\end{tabular}




\footnotetext{
a Total mass of metal

MPCD $=$ Maximum peak current density

$\mathrm{DMC}=$ Highly graphitic disordered mesoporous carbons
}

\subsubsection{Non Pt catalyst or Pt Free catalyst}

Among various noble metals studied, Pd possesses ORR activity close to that of Pt [178]. Platinum-free Pd and Pd-alloy catalysts have been studied as cathode materials for ORR in acid medium [179,180]. As palladium is cheaper than platinum, Pd based ORR catalysts might address the cost issues of platinum to some extent. But the less ORR activity of Pd than pt and poor stability of Pd at higher potentials, about $+0.8 \mathrm{~V}$ vs NHE, hinders it commercial application. The challenge is to develop appropriate Pd-alloys with specific compositions, with good activity for oxygen reduction (or atleast the same as platinum) and better stability in acid medium for PEFC applications. This is quite important as $\mathrm{Pd}$ is at least 50 times more available/distributed globally than Pt, and each of the alloying elements are more available than $\mathrm{Pd}$ itself [179]. To improve the catalytic activity of $\mathrm{Pd}$, various bimetallic Pd alloys such as Pd-Co, Pd-Au, Pd-Ni has been employed [180]. The activity for oxygen reduction of ternary $\mathrm{Pd}-\mathrm{Co}$-based catalysts has also been investigated. Raghuveer et al. [182] reported the effect of $\mathrm{Au}$ addition to a $\mathrm{Pd}-\mathrm{Co}$ catalyst. The resulting $\mathrm{Pd}-\mathrm{Co}-\mathrm{Au}$ presented ORR activity comparable or better, depending on the preparation method, than that of a commercial Pt/C catalyst. In a similar work, Raghuveer et al. found that a Pd-CoMo catalyst with a Pd: Co: Mo atomic ratio of 70: 20: 10 exhibited higher catalytic activity, more like the $\mathrm{Pd}-\mathrm{Co}-\mathrm{Au}$ catalyst, than the commercial Pt catalyst, but with excellent chemical stability unlike the $\mathrm{Pd}-\mathrm{Co}-\mathrm{Au}$ catalyst [183]. The ORR activity of $\mathrm{Pd}-\mathrm{Fe}$ catalysts has also been extensively investigated [153-156]. In all cases the highest ORR activity was presented by the catalyst with a $\mathrm{Pd} / \mathrm{Fe}$ atomic ratio of $3: 1$. Furthermore, the activity of $\mathrm{Pd}_{3} \mathrm{Fe} / \mathrm{C}$ is higher than that of the state of- the-art commercial $\mathrm{Pt} / \mathrm{C}$ electrocatalysts [204]. Binary $\mathrm{Pd}-\mathrm{M}$ and ternary $\mathrm{Pd}-\mathrm{Co}-\mathrm{M}$ catalysts, in particular $\mathrm{Pd}-\mathrm{Co}-\mathrm{Au}$ and $\mathrm{Pd}-\mathrm{Co}-\mathrm{Mo}$, are promising materials when used as cathode material in fuel cells. Indeed, these catalysts possess a similar/higher ORR activity than Pt. In this case Pd could fully substitute Pt as cathode material in fuel cells. An understanding of the origin of their high activities may help us in designing inexpensive and more active catalysts.

Table 7: Summary of the data on Non-Pt based cathodes.

\begin{tabular}{|c|c|c|c|c|c|}
\hline Catalyst & $\begin{array}{c}\text { Specific } \\
\text { Preparation } \\
\text { method }\end{array}$ & $\begin{array}{c}\text { Activity } \\
\left(\mathrm{mAcm}^{-2}\right)\end{array}$ & $\begin{array}{c}\text { Catalytic } \\
\text { activity } \\
\mathrm{A} \mathrm{g}^{-1} \mathbf{P t}\end{array}$ & $\begin{array}{c}\text { towards } \mathrm{O}_{2} \\
\text { reduction } \\
\text { Vs Pt } \\
\text { (no of }\end{array}$ & $\begin{array}{c}\text { Measurement } \\
\text { conditions }\end{array}$ \\
\hline
\end{tabular}




\begin{tabular}{|c|c|c|c|c|c|}
\hline & & & & $\begin{array}{c}\text { electrons } \\
\text { transferred) }\end{array}$ & \\
\hline \multicolumn{6}{|l|}{ Monometallic } \\
\hline $\mathrm{Pd} / \mathrm{C}$ [195] & $\begin{array}{l}\text { Borohydride } \\
\text { Reduction }\end{array}$ & $\mathrm{N} / \mathrm{A}$ & $\mathrm{N} / \mathrm{A}$ & less & $\begin{array}{l}\mathrm{O}_{2} \text {-saturated } 0.5 \mathrm{M} \\
\mathrm{H}_{2} \mathrm{SO}_{4}\end{array}$ \\
\hline $\mathrm{Pd}-\mathrm{WO}_{3} / \mathrm{C}$ [195] & $\begin{array}{l}\text { Borohydride } \\
\text { Reduction }\end{array}$ & $\mathrm{N} / \mathrm{A}$ & $\mathrm{N} / \mathrm{A}$ & Comparable & $\begin{array}{l}\mathrm{O}_{2} \text {-saturated } 0.5 \mathrm{M} \\
\mathrm{H}_{2} \mathrm{SO}_{4}\end{array}$ \\
\hline $\begin{array}{l}\mathrm{Pd} / \mathrm{TiO}_{2} \text { nanotubes } \\
{[196]}\end{array}$ & $\begin{array}{l}\text { Electrochemical } \\
\text { Deposition }\end{array}$ & $\mathrm{N} / \mathrm{A}$ & $\mathrm{N} / \mathrm{A}$ & $\begin{array}{l}\mathrm{Pd} / \mathrm{TiO}_{2}< \\
\mathrm{Pt}\end{array}$ & $\begin{array}{l}\mathrm{O}_{2} \text {-saturated } 0.5 \mathrm{M} \\
\mathrm{H}_{2} \mathrm{SO}_{4}\end{array}$ \\
\hline $\begin{array}{l}\mathrm{Au} / \mathrm{TiO}_{2} \text { nanotube } \\
{[197]}\end{array}$ & $\mathrm{N} / \mathrm{A}$ & $\mathrm{N} / \mathrm{A}$ & $\mathrm{N} / \mathrm{A}$ & $\mathrm{N} / \mathrm{A}$ & $\begin{array}{l}\mathrm{O}_{2} \text { saturated } 0.1 \mathrm{M} \\
\mathrm{HClO}_{4}+0.01 \mathrm{M} \\
\mathrm{NaClO}_{4}\end{array}$ \\
\hline $\begin{array}{l}\mathrm{Au} / \mathrm{PDDA}-\mathrm{MWCNT} \\
{[198]}\end{array}$ & $\begin{array}{l}\text { Electrostatic } \\
\text { layer-by-layer } \\
\text { technique }\end{array}$ & $\begin{array}{l}1.6(\text { at } \\
0.05 \mathrm{~V})\end{array}$ & $\mathrm{N} / \mathrm{A}$ & $\begin{array}{l}\mathrm{N} / \mathrm{A} \\
\left(\mathrm{n}=2 \mathrm{e}^{-}\right)\end{array}$ & $\begin{array}{l}\mathrm{O}_{2} \text {-saturated } 0.5 \mathrm{M} \\
\mathrm{H}_{2} \mathrm{SO}_{4}\end{array}$ \\
\hline $\begin{array}{l}\text { Pd/HPW-PDDA- } \\
\text { MWCNTs [199] }\end{array}$ & Impregnation & $\mathrm{N} / \mathrm{A}$ & $\mathrm{N} / \mathrm{A}$ & Comparable & $\begin{array}{l}\mathrm{O}_{2} \text {-saturated } 0.5 \mathrm{M} \\
\mathrm{H}_{2} \mathrm{SO}_{4}\end{array}$ \\
\hline \multicolumn{6}{|l|}{ Bimetallic } \\
\hline $\mathrm{Pd}_{70} \mathrm{Co}_{30} / \mathrm{C}[181]$ & $\begin{array}{l}\text { Modified Polyol } \\
\text { reduction }\end{array}$ & $\mathrm{N} / \mathrm{A}$ & $\begin{array}{l}300(0.9 \\
V)\end{array}$ & $\mathrm{N} / \mathrm{A}$ & Nafion 112 \\
\hline $\mathrm{Pd}_{4} \mathrm{Co} / \mathrm{C}[184]$ & $\begin{array}{l}\text { Modified Polyol } \\
\text { reduction }\end{array}$ & $\mathrm{N} / \mathrm{A}$ & $\mathrm{N} / \mathrm{A}$ & $\mathrm{N} / \mathrm{A}$ & $\begin{array}{l}\mathrm{O}_{2} \text {-saturated } 0.5 \mathrm{M} \\
\mathrm{H}_{2} \mathrm{SO}_{4}\end{array}$ \\
\hline $\mathrm{PdCo} / \mathrm{C}[200]$ & Polyol reduction & $\mathrm{N} / \mathrm{A}$ & $\mathrm{N} / \mathrm{A}$ & $\begin{array}{l}\text { Comparable } \\
\left(\mathrm{n}=4 \mathrm{e}^{-}\right)\end{array}$ & $\begin{array}{l}\mathrm{O}_{2} \text {-saturated } 0.5 \mathrm{M} \\
\mathrm{H}_{2} \mathrm{SO}_{4}\end{array}$ \\
\hline $\mathrm{Pd}_{75} \mathrm{Co}_{25}[201]$ & Electrodeposition & $\mathrm{N} / \mathrm{A}$ & $\mathrm{N} / \mathrm{A}$ & Comparable & $\begin{array}{l}\mathrm{O}_{2} \text {-saturated } 0.5 \mathrm{M} \\
\mathrm{H}_{2} \mathrm{SO}_{4}\end{array}$ \\
\hline $\mathrm{PdCo} / \mathrm{C}$ [202] & $\begin{array}{l}\text { Formalehyde, } \\
\text { Borohydride } \\
\text { and Polyol } \\
\text { Reduction }\end{array}$ & $\mathrm{N} / \mathrm{A}$ & $\mathrm{N} / \mathrm{A}$ & less & $\begin{array}{l}\mathrm{O}_{2} \text {-saturated } 0.5 \mathrm{M} \\
\mathrm{H}_{2} \mathrm{SO}_{4}\end{array}$ \\
\hline Pd-Co dendrites [203] & $\begin{array}{l}\text { Electrodeposition } \\
\text { and dealloying }\end{array}$ & $\mathrm{N} / \mathrm{A}$ & $\mathrm{N} / \mathrm{A}$ & $\mathrm{N} / \mathrm{A}$ & $\begin{array}{l}\mathrm{O}_{2} \text {-saturated } 0.5 \mathrm{M} \\
\mathrm{H}_{2} \mathrm{SO}_{4} 30^{\circ} \mathrm{C} .\end{array}$ \\
\hline $\mathrm{Pd}-\mathrm{Ti} / \mathrm{C}$ [182] & $\begin{array}{l}\text { Reverse } \\
\text { Microemulsion }\end{array}$ & $\mathrm{N} / \mathrm{A}$ & $\mathrm{N} / \mathrm{A}$ & Comparable & $\begin{array}{l}\mathrm{O}_{2} \text {-saturated } 0.5 \mathrm{M} \\
\mathrm{H}_{2} \mathrm{SO}_{4}\end{array}$ \\
\hline
\end{tabular}




\begin{tabular}{|c|c|c|c|c|c|}
\hline Pd- Mo alloy [189] & $\begin{array}{l}\text { Organometallic } \\
\text { decomposition }\end{array}$ & $\mathrm{N} / \mathrm{A}$ & $\mathrm{N} / \mathrm{A}$ & $\begin{array}{l}\mathrm{PdMo}<\mathrm{Pt} \\
\text { Comparable }\end{array}$ & $\begin{array}{l}\mathrm{O}_{2} \text {-saturated } 0.5 \mathrm{M} \\
\mathrm{H}_{2} \mathrm{SO}_{4}\end{array}$ \\
\hline Pd-Fe nanorods [193] & $\begin{array}{l}\text { Organic phase } \\
\text { reaction and } \\
\text { Thermal } \\
\text { decomposition }\end{array}$ & $\mathrm{N} / \mathrm{A}$ & $\begin{array}{l}284(0.85 \\
V)\end{array}$ & $\begin{array}{l}\text { Excellent } \\
\text { Pd-Fe } \\
\text { nanorods }> \\
\text { Pt }\end{array}$ & $\begin{array}{l}\mathrm{O}_{2} \text {-saturated } 0.1 \mathrm{M} \\
\mathrm{HClO}_{4}\end{array}$ \\
\hline $\mathrm{Pd}_{3}-\mathrm{Fe} / \mathrm{C}[204]$ & $\begin{array}{l}\text { Thermal } \\
\text { decomposition }\end{array}$ & $\begin{array}{l}0.791 \\
(0.85 \mathrm{~V})\end{array}$ & $\mathrm{N} / \mathrm{A}$ & $\begin{array}{l}\text { Excellent } \\
\mathrm{Pd}_{3}-\mathrm{Fe} / \mathrm{C} \\
>\mathrm{Pt} / \mathrm{C}\end{array}$ & $\begin{array}{l}\mathrm{O}_{2} \text {-saturated } 0.1 \mathrm{M} \\
\mathrm{HClO}_{4}\end{array}$ \\
\hline $\mathrm{PdFe} / \mathrm{C}$ [194] & $\begin{array}{l}\text { Pulse microwave } \\
\text { assisted polyol }\end{array}$ & $\mathrm{N} / \mathrm{A}$ & $\mathrm{N} / \mathrm{A}$ & $\begin{array}{l}\text { Comparable } \\
\left(\mathrm{n}=4 \mathrm{e}^{-}\right)\end{array}$ & $\begin{array}{l}\mathrm{O}_{2} \text {-saturated } 0.5 \mathrm{M} \\
\mathrm{H}_{2} \mathrm{SO}_{4}\end{array}$ \\
\hline $\mathrm{Pd}_{80} \mathrm{Ni}_{20}[187]$ & Modified Polyol & $\mathrm{N} / \mathrm{A}$ & $\begin{array}{l}100^{\mathrm{a}}(0.7 \\
\mathrm{V})\end{array}$ & $\mathrm{N} / \mathrm{A}$ & $\begin{array}{l}\mathrm{O}_{2} \text {-saturated } 0.5 \mathrm{M} \\
\mathrm{H}_{2} \mathrm{SO}_{4}\end{array}$ \\
\hline Pd-W alloy [188] & $\begin{array}{l}\text { Organometallic } \\
\text { decomposition }\end{array}$ & $\mathrm{N} / \mathrm{A}$ & $\mathrm{N} / \mathrm{A}$ & $\begin{array}{l}\mathrm{PdW}<\mathrm{Pt} \\
\text { Comparable }\end{array}$ & $\begin{array}{l}\mathrm{O}_{2} \text {-saturated } 0.5 \mathrm{M} \\
\mathrm{H}_{2} \mathrm{SO}_{4}\end{array}$ \\
\hline $\begin{array}{l}\text { Nanotubular } \\
\text { mesoporous } \\
\text { Pd-Cu [205] }\end{array}$ & $\begin{array}{l}\text { Galvanic } \\
\text { replacement } \\
\text { reaction }\end{array}$ & $\mathrm{N} / \mathrm{A}$ & $\mathrm{N} / \mathrm{A}$ & $\mathrm{N} / \mathrm{A}$ & $\begin{array}{l}\mathrm{O}_{2} \text {-saturated } 0.1 \mathrm{M} \\
\mathrm{HClO}_{4}\end{array}$ \\
\hline \multicolumn{6}{|l|}{ Trimetallic } \\
\hline $\mathrm{PdCoAu} / \mathrm{C}$ [182] & $\begin{array}{l}\text { Reverse } \\
\text { Microemulsion }\end{array}$ & $\mathrm{N} / \mathrm{A}$ & $\mathrm{N} / \mathrm{A}$ & Comparable & $\mathrm{N} / \mathrm{A}$ \\
\hline $\mathrm{Pd}_{70} \mathrm{Co}_{20} \mathrm{Au}_{10} / \mathrm{C}[183]$ & $\begin{array}{l}\text { Borohydride } \\
\text { Reduction }\end{array}$ & $\mathrm{N} / \mathrm{A}$ & $\mathrm{N} / \mathrm{A}$ & Comparable & Nafion 115 \\
\hline $\mathrm{Pd}_{70} \mathrm{Co}_{20} \mathrm{Mo}_{10} / \mathrm{C}$ [184] & $\mathrm{N} / \mathrm{A}$ & $\mathrm{N} / \mathrm{A}$ & $\mathrm{N} / \mathrm{A}$ & $\mathrm{N} / \mathrm{A}$ & $\begin{array}{l}\mathrm{O}_{2} \text {-saturated } 0.5 \mathrm{M} \\
\mathrm{H}_{2} \mathrm{SO}_{4}\end{array}$ \\
\hline $\mathrm{PdCoMo/C} \mathrm{[192]}$ & $\begin{array}{l}\text { Borohydride } \\
\text { Reduction }\end{array}$ & $\mathrm{N} / \mathrm{A}$ & $\mathrm{N} / \mathrm{A}$ & Comparable & $\begin{array}{l}\mathrm{O}_{2} \text {-saturated } 0.5 \mathrm{M} \\
\mathrm{H}_{2} \mathrm{SO}_{4}\end{array}$ \\
\hline $\begin{array}{l}\mathrm{Pd}-\mathrm{Co}- \\
\mathrm{Mo}(7: 2: 1) / \mathrm{CDX} 975 \\
{[190]}\end{array}$ & $\begin{array}{l}\text { Reverse } \\
\text { Microemulsion }\end{array}$ & $4.1(0.7 \mathrm{~V})$ & $\mathrm{N} / \mathrm{A}$ & Comparable & $\begin{array}{l}\mathrm{O}_{2} \text {-saturated } 0.5 \mathrm{M} \\
\mathrm{H}_{2} \mathrm{SO}_{4}\end{array}$ \\
\hline $\mathrm{Pd}_{0.5} \mathrm{Ni}_{\mathrm{x}} \mathrm{Se}_{(0.5 \mathrm{Lx})}[206]$ & $\begin{array}{l}\text { Borohydride } \\
\text { Reduction }\end{array}$ & $\mathrm{N} / \mathrm{A}$ & $\mathrm{N} / \mathrm{A}$ & $\begin{array}{l}\mathrm{N} / \mathrm{A} \\
\left(\mathrm{n}=4 \mathrm{e}^{-}\right)\end{array}$ & $\begin{array}{l}\mathrm{O}_{2} \text {-saturated } 0.5 \mathrm{M} \\
\mathrm{H}_{2} \mathrm{SO}_{4}\end{array}$ \\
\hline $\mathrm{Pd}_{3} \mathrm{Fe}_{1} \mathrm{Ir}_{1} / \mathrm{C}$ [191] & colloidal & $\mathrm{N} / \mathrm{A}$ & $\mathrm{N} / \mathrm{A}$ & Comparable & $\begin{array}{l}\mathrm{O}_{2} \text {-saturated } 0.5 \mathrm{M} \\
\mathrm{H}_{2} \mathrm{SO}_{4}\end{array}$ \\
\hline $\begin{array}{l}\mathrm{Pd} / \mathrm{Ag} / \mathrm{Au} \\
\text { nanosponges [208] }\end{array}$ & $\begin{array}{l}\text { self-regulated } \\
\text { reduction }\end{array}$ & $\mathrm{N} / \mathrm{A}$ & $\mathrm{N} / \mathrm{A}$ & $\begin{array}{l}\mathrm{N} / \mathrm{A} \\
\left(\mathrm{n}=2 \mathrm{e}^{-}\right)\end{array}$ & $\begin{array}{l}\mathrm{O}_{2} \text {-saturated 1 M } \\
\mathrm{H}_{2} \mathrm{SO}_{4}\end{array}$ \\
\hline
\end{tabular}

${ }^{a}$ total mass of metal 


\subsubsection{Non-Noble metal catalysts}

Great efforts have been made in recent years to reduce catalyst costs and improve the activity of non-noble-metal catalysts for ORR [209,210]. A Pt-free catalyst that has attracted most attention over the years is the transition metal chalcogenide/s [211, 212]. Two major transition metal chalcogenides based on structure have been explored as electrocatalysts for ORR: chevrel phase-type compounds (e.g., $\mathrm{Mo}_{4} \mathrm{Ru}_{2} \mathrm{Se}_{8}$ [211]) and amorphous phase compounds (e.g., $\mathrm{Ru}_{\mathrm{x}} \mathrm{Mo}_{\mathrm{y}} \mathrm{Se}_{z}, \mathrm{Ru}_{\mathrm{x}} \mathrm{S}_{\mathrm{y}}$ [213-216]). Chalcogenides can catalyze both 2-electron and 4-electron $\mathrm{O}_{2}$ reduction, depending on the catalysts used. For example, $\mathrm{Mo}_{4} \mathrm{Ru}_{2} \mathrm{Se}_{8}$, $\mathrm{Ru}_{1.92} \mathrm{Mo}_{0.08} \mathrm{SeO}_{4}, \mathrm{Ru}_{\mathrm{x}} \mathrm{S}_{\mathrm{y}}(\mathrm{CO})_{\mathrm{n}}, \mathrm{Ru}_{\mathrm{x}} \mathrm{Se}_{\mathrm{y}}$, etc. catalyze 4-electron transfer [210-216], while WCo-Se catalyzes a 2-electron $\mathrm{O}_{2}$ reduction reaction [217]. Further, a recent study on chalcogen-free RuNx chelate compounds [218, 219] has demonstrated comparable catalytic activity and selectivity to Pt-based catalysts for four-electron oxygen reduction in acidic media. Detailed reviews on non-noble metal ORR catalysts are reported [220, 221].

\section{Transition metal macrocyles}

The catalytic nature of cobalt pthalocyanine was discovered by Jasinski [222], who reported high electrocatalytic activity of cobalt pthalocyanines towards ORR. Subsequently, catalysts were produced by pyrolyzing metal-N4 macrocycles adsorbed on carbon black in inert atmosphere and the effect of thermal treatment was studied. The studies suggest that, rather than being directly part of the nitrogen active sites, metal particles may act as the catalysts for active site formation during high-temperature heat treatment [223]. It was also reported that the heat treatment can destroy the ligand structure and form surface $\mathrm{Fe}-\mathrm{Nx}$ or Co-Nx species which are active towards ORR [224, 225]. In particular, the presence of Fe or Co may facilitate the incorporation of pyridinic- $\mathrm{N}$ and quaternary- $\mathrm{N}$ into the carbon matrix with a strong Lewis base, which can increase electron-donor property of the N-doped carbon. Thus, it will weaken the $\mathrm{O}-\mathrm{O}$ bond via the bonding between oxygen and nitrogen and/or the adjacent carbon atom and increase the catalytic activity of the $\mathrm{N}$-doped carbon-based catalysts toward the ORR [210].

Cobalt and iron-based nitrogen-containing catalysts (i.e., Co-N/C and $\mathrm{Fe}-\mathrm{N} / \mathrm{C}$ ) are among the most promising substitutes for $\mathrm{Pt} / \mathrm{C}$, owing to their comparable catalytic activities toward ORR at much lower cost. It has been shown that the nitrogen content and surface morphology in these catalysts are of great importance for catalytic activity toward ORR. Heat treatments of these transition metal macrocycles seem to have a positive effect on its catalytic activity in strong acid electrolytes [224,225]. Although the transition metal macrocycles show comparable activity to those of Pt-based catalysts for ORR in acidic media, their level of stability is a major drawback when they are employed as PEM fuel cell catalysts. At this stage, the priority for fuel cell catalyst development is to explore new catalysts with enhanced catalytic activity

Zelenay et al. [100] explored Co-polypyrrole (CoPPy) material as a PEM fuel cell cathode catalyst. The composite CoPPy catalyst, even without heat treatment, could generate a power 
density of $\sim 0.15 \mathrm{Wcm}^{-2}$ in a $\mathrm{H}_{2}-\mathrm{O}_{2}$ fuel cell and displayed no signs of performance degradation for more than 100 hrs. They reported that hetero-atomic polymers can be used not only to stabilize the non-noble metals in a PEM fuel cell environment but also to generate active sites for ORR. The interaction between the catalyst and oxygen also demonstrates that CoPPy forms stable end-on, side-on, and bridged oxygen adducts. Furthermore, the side-on and bridged oxygen adducts were found to be more stable than end-on adducts. Since side-on and bridged oxygen adducts greatly elongate O-O bond lengths, they generally lead to 4-electron reduction products. Thereby, they differ from Co macrocyclic catalysts, which cannot form these types of oxygen adducts and generally yield 2-electron reduction products. The increase of $\mathrm{N}$ content, a key factor for catalytic activity of Co- and Fe-based N-containing catalysts, is the main reason for enhanced electro-catalytic activity of Co-PPy-TsOH/C toward ORR as compared to that of Co-PPy/C. Doping Co$\mathrm{PPy} / \mathrm{C}$ with $\mathrm{TsOH}$ is a valuable way to improve the catalytic activity of $\mathrm{Co}-\mathrm{PPy} / \mathrm{C}$ toward ORR [228]. The MWCNT supported Co-PPy electrocatalysts promise to deliver high ORR activity without any noticeable loss in performance over long PEMFC operating times [229].

Another class of non noble metals, perovskite-type and spinel-type oxides and tungsten carbides has also been explored as alternative electrocatalysts to platinum. They show promising catalytic activities towards the oxygen reduction and hydrogen oxidation reactions. However, most of these catalysts demonstrate activity and stability in alkaline solutions. In a PEM fuel cell, which uses strong acidic electrolytes, these catalysts are not favorable [230-235].

\section{$4 \quad$ Catalyst Supports}

Carbon is the typical catalyst support material for fuel cell applications due to its large surface area, high electrical conductivity and well-developed pore structure. However, the carbon support, especially at the cathode, is subjected to severe corrosion in the presence of water, according to the following reaction [242-247]:

$\mathrm{C}+2 \mathrm{H}_{2} \mathrm{O} \rightarrow \mathrm{CO}_{2}+4 \mathrm{H}^{+}+4 \mathrm{e}$

Agglomeration of $\mathrm{Pt}$ catalyst on the carbon surface is inevitable as carbon corrosion becomes more severe. This effect causes the performance of catalysts to degrade quickly, resulting in short lifetime of PEMFC which is not adequate for most of its projected applications. Therefore, highly stable catalyst supports are required to enhance catalyst lifetime. Some of the alternative supports studied include conducting metal oxides and conducting polymers.

Vulcan has been extensively studied and used as supports for fuel cell catalysts. Apart from Vulcan, several carbon materials have been investigated as catalyst supports for PEMFCs. Carbon nanotubes (CNTs) have been employed to improve catalyst durability, where $\mathrm{Pt} / \mathrm{CNT}$ s showed a lower electrochemical surface area loss, a higher ORR activity and better corrosion resistance as compared to $\mathrm{Pt} / \mathrm{C}[239,241]$. Carbon aerogel increases the contact 
area between Pt and electrolyte because of its high pore size distributions [236], and accordingly, the catalytic surface area of Pt on carbon aerogel is higher as compared to Vulcan XC-72. However, the chemical stability of the catalyst is limited due to the amorphous property of carbon aerogel. Graphene sheets, a two-dimensional carbon material has high surface area and conductivity. Pt catalysts on functionalized graphene sheets exhibits enhanced activity and stability for oxygen reduction [256].

Semiconductor ceramics in particular, $\mathrm{Ti}_{4} \mathrm{O}_{7}$ exhibits a high electrical conductivity of $1000 \mathrm{~S}$ $\mathrm{cm}^{-1}$ at room temperature, which is considerably higher than the graphitized carbon (conductivity of $727 \mathrm{~S} \mathrm{~cm}^{-1}$ ) [254]. Accordingly, the $\mathrm{Ti}_{4} \mathrm{O}_{7}$ support would be applicable to PEMFC electrocatalysts without degrading the intrinsic catalytic activity of $\mathrm{Pt}$, so that $\mathrm{Pt} / \mathrm{Ti}_{4} \mathrm{O}_{7}$ would be a potentially durable catalyst material for PEMFCs.

Tungsten carbide (WC) has also attracted attention and the thermal and electrochemical stability of WC catalyst supports have been investigated. WC was found to be more thermally and electrochemically stable than carbon supports. However, its stability in acid electrolyte is not ideal because WC can be corroded in sulfuric acid, which decreases the catalyst's stability [260].

Recently, it was also reported that titanium nitride (TiN) supported Pt for PEM fuel cells showed higher catalytic performance than conventional Pt/C catalysts [264], but the durability of TiN as the support material is not clear yet. Further studies are necessary to understand TiN as a catalyst support and especially evaluate its durability properties.

Titanium diboride $\left(\mathrm{TiB}_{2}\right)$ exhibits many superior properties, including high melting point, great hardness, good electrical, high thermal conductivity, excellent thermal stability and corrosion resistance in acidic medium. The stability of $\mathrm{Pt} / \mathrm{TiB}_{2}$ is approximately 4 times better than that of the commercial $\mathrm{Pt} / \mathrm{C}$ [265].

Table 8. Summary of the data on catalyst supports.

\begin{tabular}{|c|c|c|c|}
\hline Carbon support & $\begin{array}{c}\text { Metal oxide } \\
\text { support }\end{array}$ & $\begin{array}{c}\text { Metal } \\
\text { carbide } \\
\text { and nitride } \\
\text { support }\end{array}$ & Polymer support \\
\hline Carbon xerogel [236] & $\mathrm{Pd} / \mathrm{WO}_{3} / \mathrm{C}[249]$ & $\mathrm{Pt} / \mathrm{CrN}$ & Pt/Polypyrrole [266,267] \\
\hline Ordered mesoporous & $\mathrm{Pt} / \mathrm{SnO}_{2} / \mathrm{C}[250]$ & [259] & Pt/Polyaniline [268] \\
\hline carbon [237] & $\mathrm{Pt} / \mathrm{SiO}_{2}[251]$ & $\mathrm{Pt} / \mathrm{W}_{2} \mathrm{C}$ & Pt/Polypyrrole-C ${ }_{2}[269]$ \\
\hline Carbon Nanotube (CNT) & $\mathrm{Pt} / \mathrm{S}-\mathrm{ZrO}_{2}[253]$ & {$[260]$} & Pt/ poly(o-phenylenediamine) [270] \\
\hline$[238]$ & $\mathrm{Pt} / \mathrm{Ti}_{4} \mathrm{O}_{7}[254]$ & $\mathrm{Pt}-\mathrm{W}_{2} \mathrm{C} / \mathrm{C}$ & Pt/ poly-1,5-diaminoanthraquinone \\
\hline Graphene [256] & $\mathrm{Pt} / \mathrm{Nb}-\mathrm{TiO}_{2}[255]$ & {$[261]$} & {$[271]$} \\
\hline Nitrogen-Doped Carbon & $\mathrm{Pt} / \mathrm{TiO}_{2} / \mathrm{C}[258]$ & $\mathrm{Pt} / \mathrm{SiC}[262]$ & Pt/poly(3,4ethylenedioxythiophene)/ \\
\hline Nanotube $[241,242]$ & $\mathrm{Pt} / \mathrm{TiO}_{2}$ nanotube & Pt/TiC & poly(styrene 4-sulfonate) ${ }_{3}[248]$ \\
\hline Nitrogen -Doped carbon & {$[257]$} & $\begin{array}{l}{[263]} \\
\text { Pt/TiN }\end{array}$ & Pd / poly( $N$-acetylaniline) nanorods \\
\hline
\end{tabular}

Page $\mid 32$ 


\begin{tabular}{|l|l|l|l|}
\hline$[240]$ & & {$[264]$} & {$[272]$} \\
& & $\mathrm{Pt}^{2} / \mathrm{TiB}_{2}$ & \\
& & & \\
& & & \\
& & & \\
\hline
\end{tabular}

Among conducting polymers, conductive polypyrrole (PPy) can be considered as a promising catalyst support, for its good electrical conductivity, high environmental stability, and the merit of simple preparation by both chemical and electrochemical processes [266]. The PPy support is highly resistive towards oxidation at potentials as high as $1.8 \mathrm{~V}$ and the Pt/PPy catalyst exhibited ORR activity twice as high as that of Pt black catalyst. The fuel cell polarization curves for the Pt/PPy catalysts are comparable with that of commercial E-TEK $\mathrm{Pt} / \mathrm{C}$ catalyst and demonstrated good ORR kinetics [267].

\section{Gas diffusion layer (GDL)}

The GDLs are directly adjacent to the bipolar plates and typically consist of two layers, the macroporous substrate layer and a microporous layer (MPL). The porous gas diffusion layer in PEM fuel cells ensures that reactants effectively diffuse to the catalyst layer and minimize mass transport overpotential. Typically, gas diffusion layers are constructed from porous carbon paper, or carbon cloth, with a thickness in the range of 100-300 $\mu \mathrm{m}$. The GDLs are gas permeable and help distribute gases to the catalyst layer, conduct electrical current, and also provide a network of paths for liquid water to move from the MEA to the flow channel. The gas diffusion layer also assists in water management by allowing an appropriate amount of water to reach, and be held at, the membrane for hydration. In addition, gas diffusion layers are typically wet-proofed with a PTFE (Teflon) coating to ensure that the pores of the gas diffusion layer do not become congested with liquid water [18]. The macroporous substrate layer consists of a carbon fibre matrix with a large void volume, typically $75-85 \%$, and a primarily hydrophobic MPL consisting of carbon black mixed with fluoropolymer. The cathode GDL normally has an attached MPL; the anode GDL may or may not have a MPL.

Application of the carbon/PTFE mixture flattens out any roughness of the cloth or paper and improves the gas and water transport properties. An optimum GDL is one that allows an appropriate amount of water vapor to reach the membrane/electrode interface, keeping the membrane humidified and thereby improving the cell efficiency. It allows the liquid water produced at the cathode to leave the cell and avoids flooding. The GDL is typically wet-proofed to ensure that at least some, and hopefully most, of the pores in the carbon 
cloth or paper do not become clogged with water, which would prevent the rapid gas diffusion necessary for a good rate of reaction to occur at the electrodes.

The PTFE amount used in the microporous carbon layer, the types of coating used, and the Nafion and catalyst amounts used in the catalyst layer affects the cell performance. As PTFE content increases, the pore size decreases, resulting in higher mass transport resistance, while if the PTFE content gets too low, the water removal capability drops, resulting in electrode flooding. Williams et al. [54] suggested that the optimal PTFE content in an MPL for nearsaturated operation is between 15 and $20 \mathrm{wt} \%$. Extensive review on GDL has recently been published [275].

\section{$6 \quad$ Membrane electrode assembly (MEA)}

Membrane electrode assembly (MEA), as termed, is the assembly of the membrane and electrodes. As all the reactions within the fuel cell occur in the MEA, it is widely referred as the heart of the fuel cell. The MEA consists of a proton exchange membrane, catalyst layers and gas diffusion layers (GDL). Typically, these components are fabricated individually and then pressed together at high temperatures and pressures. Hence, the design and fabrication method of MEA is highly critical as it directly affects performance of the PEM fuel cell. In this section we will look at the methods used for assembling the membranes and electrodes and the methods studied to apply the catalyst layer.

There are two general modes of MEA assembly [276], as represented by a schematic in Figure 6:

(1) The most common and widely used mode is the application of the catalyst layer (CL) to the GDL, termed as the catalyst coated substrate (CCS), followed by membrane addition

(2) The other mode is to directly apply the CL to the membrane, catalyst coated membrane (CCM), followed by GDL addition.

The primary focus in the assembly of MEAs is to achieve good contact between the membrane, the GDL, and the catalyst layers. CCM mode has several advantages over CCS mode. Good contact in CCM mode maximizes better catalyst utilization, reduced loadings and improved transport properties during cell operation.

No matter the mode of MEA assembly, the catalyst layer can be prepared and applied in two separate steps (catalyst ink preparation and application) or using a single sputtering process. The catalyst ink is a mixture made of ionomer, supported catalyst and a solvent. Glycerol is often added to adjust the viscosity of the ink. Pore forming materials, e.g. ammonium salts, and sparingly soluble fillers such as lithium carbonate are added to adjust the fine and coarse porosities respectively. The catalyst layer is formed by either coating the catalyst ink to the membrane or most commonly onto the GDL, which is then hot pressed onto the membrane. A number of methods have been developed for the application of the ink. Various methods for catalyst layer fabrication applicable to both modes (CCS\&CCM) are summarized in Figure 6. The most common methods for the application of catalyst layer 
include spreading, spraying, painting, catalyst decaling, screen printing and inkjet printing. These methods are simple, scalable and can be used by industries for manufacturing. On the other-hand, alternate methods for catalyst layer fabrication such as impregnation reduction, dry spraying, catalyst powder deposition, electrodeposition, sputtering and pulsed laser deposition have the potential to minimize the catalyst loading and also minimizes the wastages during application processes and thereby should be investigated further. Other methods that have attached the interests of researchers are colloidal method, controlled self assembly, graded catalyst deposition, multiple layer sputtering, electrophoretic deposition and electrospray Technique. While performance comparisons between these MEA fabrication methods have been shown to be important, changes to processing conditions using the same MEA fabrication method such as hot pressing temperature, time, catalyst ink composition or ink processing will have a large effect on resulting PEMFC performance. The appropriateness and effectiveness of these methods are not understood yet and is currently as a research curiosity.

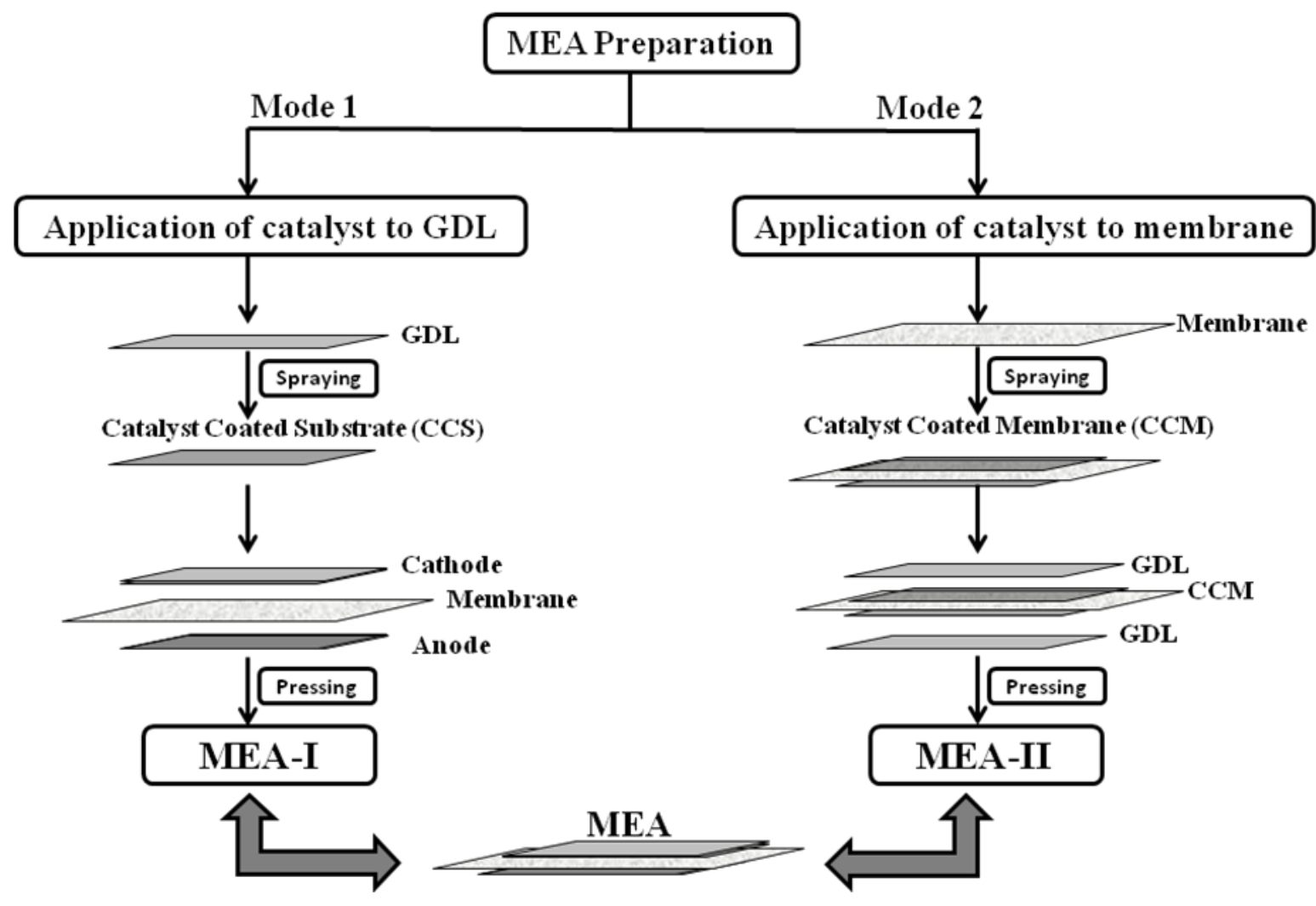

Fig. 5. The MEA preparation techniques for (a) Mode 1: CL on GDL mode and (b) Mode 2:CL on membrane mode. 


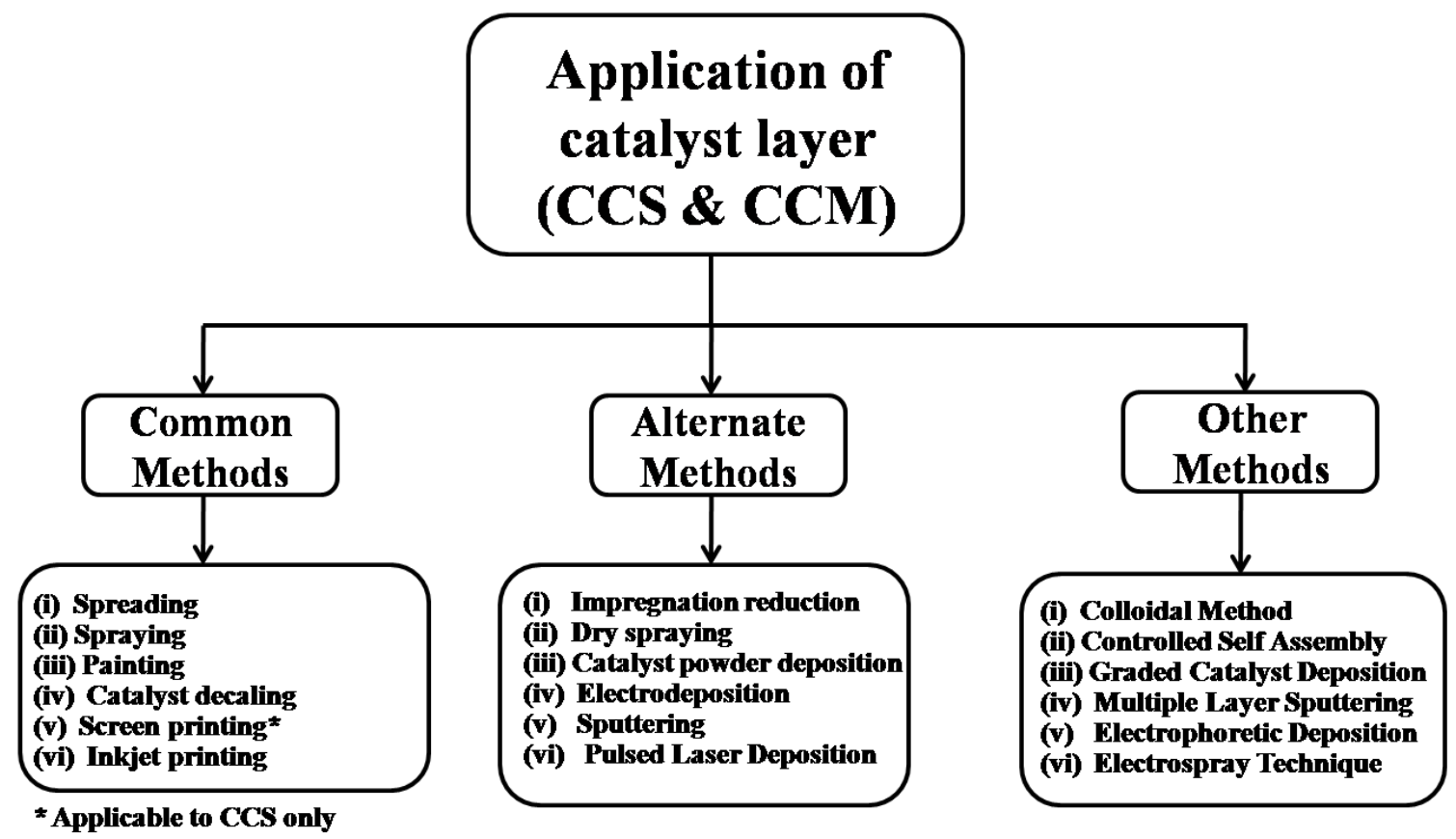

Fig. 6. Methods for catalyst layer fabrication

\section{HT-PEMFC}

Recently, there has been an increased interest globally on PEMFCs that operate above $120^{\circ} \mathrm{C}$ and are termed as high temperature PEMFCs (HT-PEMFCs). The advantages of HTPEMFC over the traditional PEMFCs are

- $\quad$ high tolerance to $\mathrm{CO}$ impurities

- improved reaction kinetics due to increase in the operating temperature

- minimum water management issues as the membrane does not require hydration

- useful heat which can be used in co-generation applications

- small cooling unit is sufficient due to larger temperature difference between the stack and the atmosphere

- overall minimize the balance o plant requirements

The performance of PEMFC will be enhanced by operating above $120{ }^{\circ} \mathrm{C}$ through improved kinetics of the cathode and anode reactions. The operating temperature will also increase the tolerance towards poisoning species such as CO. Although considerable effort has been expended to develop liquid-fueled PEMFC for transportation applications, most practitioners believe that onboard storage of hydrogen will be necessary for practical 
vehicles. HT-PEMFCs can be ideal in this case which minimises the system complexity with improved cooling system and reduced balance of plant components.

In order to achieve higher operating temperatures, many new modified membranes have been studied in recent years. Among them, poly [2,2-( $m$-phenylene)-5,5-bibenzimidazole] (polybenzimidazole, PBI) and poly(2,5-benzimidazole) (ABPBI) are most promising membranes for high temperature. These membranes are less expensive than $\mathrm{Nafion}{ }^{\circledR}$, no humidification in PEMFC application, and working temperature reaches almost $200{ }^{\circ} \mathrm{C}$ [277].

A candidate membrane material is polybenzimidazole (PBI) and ABPBI shown in Fig 7.

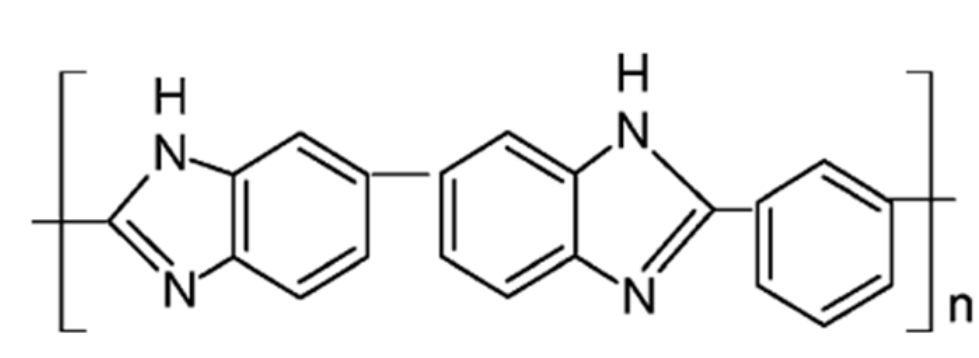

PBI

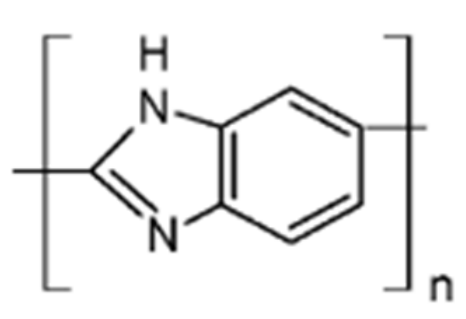

ABPBI

Fig. 7. Chemical structure of poly (2,2'-m-(phenylene)-5,5'-bibenzimidzole) and ABPBI

PBI is a relatively low cost polymer which, when doped with acid (e.g. phosphoric) has good proton conductivity and mechanical flexibility at elevated temperature along with excellent stability in reducing and oxidizing environments. PBI is a basic polymer (pKa. 6.0) which readily sorbs acid and helps to further stabilize the polymer. The PBI membranes are conductive above $100{ }^{\circ} \mathrm{C}$ even when dry. Acid doping of $50 \%$ by weight can be achieved without adverse effects to its mechanical properties. The conductivity of PBI can approach the target of $10 \mathrm{~S} / \mathrm{cm}$ set for high temperature membranes. One of the main attractions of PBI is that the solution form of the polymer can be used to cast membranes and be used as an ionomer ink in the preparation of bonded catalytic electrodes. However, the cost of PBI is still high and ABPBI membranes ( $\eta$ inh $=2.4 \mathrm{dl} \mathrm{g}^{-1}$ ) were completely dissolved in concentrated $85 \%$ phosphoric acid [277].

Development of high-temperature proton exchange membranes and catalysts for HTPEMFCs are equally important in terms of the long-term sustainability of fuel cell technology and commercialization. Some of the typically studied components are provided in Figure 8. There are several challenges, which are yet to be addressed, in terms of component development to further HT-PEMFC technology. The main challenge is the durability of the catalysts, supports and membranes at higher temperatures. High temperature PEMFC operation requires the development of catalysts with proper resilience to sintering and corrosion under working conditions. It is general opinion that corrosion 
resistant catalyst supports need to be selected for high temperature operation as well as proper anchoring of the metal phase on the support is necessary to improve stability [278].

Based on a review of the literature as well as our understanding, we would like to suggest several future research topics for high-temperature catalyst development:

(1) Development of highly durable catalyst supports, such as carbon with more graphitic components, ceramic, and carbon-ceramic composite materials, which could survive in a high-temperature environment.

(2) Enhancement of the interaction between the supports and the catalysts to stabilize Pt nanoparticles and improve catalytic activity.

(3) Development of new catalysts such as highly durable non-noble catalysts. For long-term sustainable PEMFC commercialization, non-noble catalysts are the solution because of the limited supply and high cost of Pt.

(4) Optimization of HT-PEMFC catalyst and catalyst layer composition and structure through innovative design, evaluation, as well as fundamental understanding.

(5) Improved GDL structure and GDL materials, taking into account of higher operating temperature and non-humidified gases.

(6) Membranes with better conductivity and stability

(7) Better phosphoric acid distribution in the membrane and the electrode to improve the performance

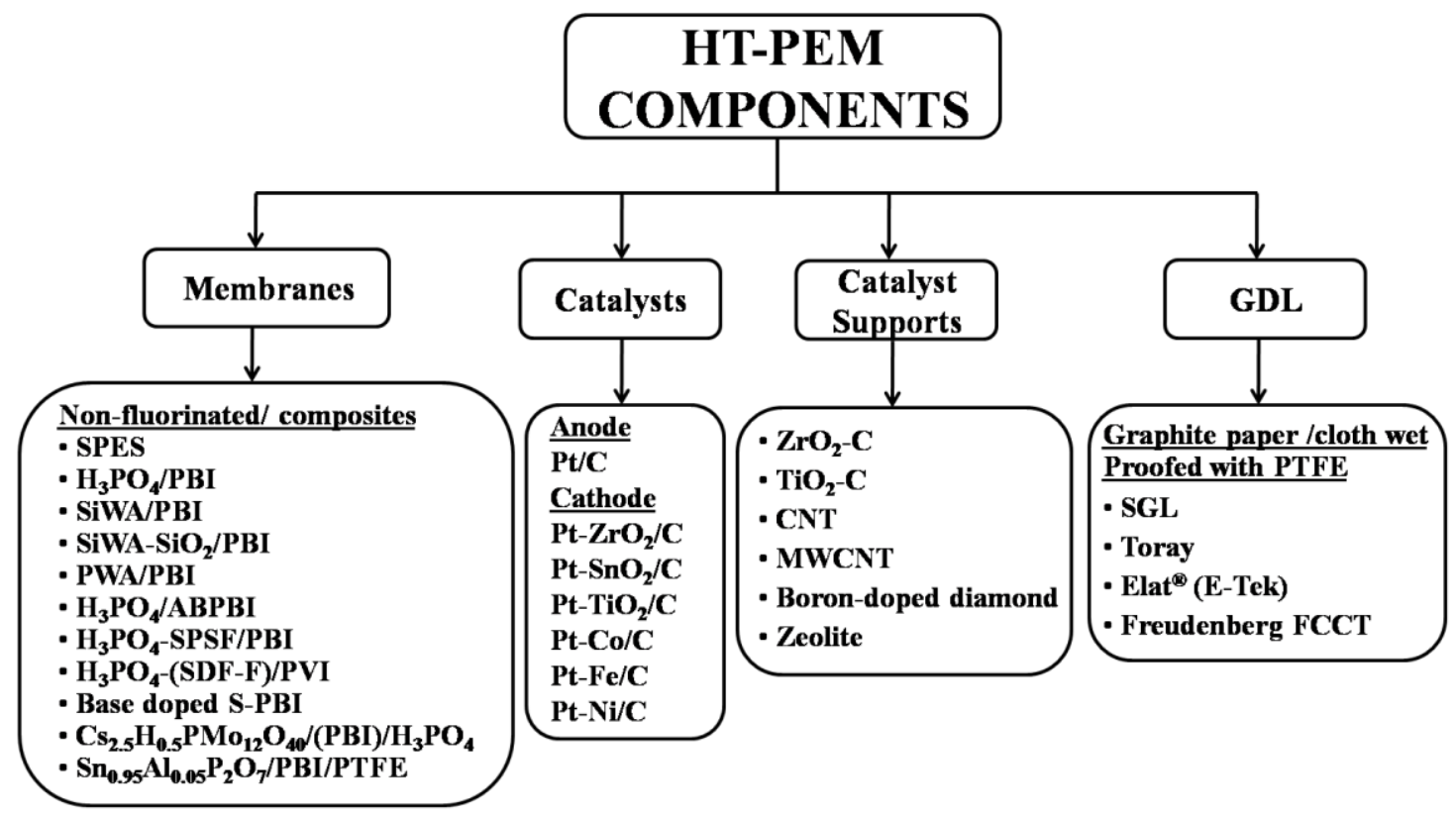

Fig. 8. Components of HTPEMFCs 


\section{$8 \quad$ Conclusions}

The PEMFC membrane electrode assembly components: catalysts, GDLs, supports and the membranes, have been studied extensively over the years and have resulted in a huge amount of literature. A concise report on the R\&D progress over the years on the MEA components is provided, highlighting the challenges that need to be addressed. In spite of dedicated research over the years, there are no real breakthroughs that address the challenges. Despite huge efforts targeting cost challenges associated with the components, substitute for Nafion or platinum based catalyst is yet to be identified. PtRu has established as the best anode catalyst whereas there is still some discrepancy over the best cathode catalyst, however, all platinum based binary catalysts appear to perform better than $\mathrm{Pt} / \mathrm{C}$ for ORR. Recently, there is an increased interest in HTPEMFCs and although recent developments seem promising, it brings along significant challenges in terms of material appropriateness and durability.

\section{$9 \quad$ References}

[1] S. Trasatti, in: Wolf Vielstich, Arnold Lamm, A. Hubert, Gasteiger (Eds.), Handbook of Fuel Cells, John Wiley and Sons, Ltd., Chichester, 2003.

[2] S.Srinivasan, D.J.Manko, H. Koch and M.A.Enayetullah, A.J. Appleby. J. Power Sources, Vol. 29 (1990), p.367

[3] G.S.Kumar, M.Raja and S. Parthasarathy, Electrochim. Acta, Vol.40 (1995), p. 285

[4] M.Cavarroc, A. Ennadjaoui, M. Mougenot, P. Brault, R. Escalier, Y. Tessier, J. Durand, S. Roualdès, T. Sauvage and C.Coutanceau, Electrochem. Commun. Vol. 11 (4), (2009), p. 859

[5] PEM Fuel Cell Catalysts and Catalyst Layers - Fundamentals and Applications, Edited by Jiujun Zhang, Springer (2008)

[6] "Multi-Year Research, Development and Demonstration Plan: Planned program activities for 2003-2010," (retrieved from web at http://www.eere.energy.gov/hydrogenandfuelcells/mypp/)).

[7] B.W. Jensen, O.W. Jensen, M. Forsyth and D.R. MacFarlane, Science, Vol. 321(2008), p. 671

[8] K.P. Gong, F. Du, Z.H. Xia, M. Durstock and L.M. Dai, Science, Vol. 323 (5915) (2009), p. 760

[9] Li X. Principle of Fuel Cells. New York: Taylor and Francis, 2006.

[10] J. Larminie, A. Dicks. Fuel cell systems explained. Chicester, England: John Wiley and Sons, 2003. 
[11] W. G. Grot, Chem. Ind., Vol. 19 (1985), p. 647

[12] M. Wakizoe, O. A. Velev and S. Srinivasan, Electrochim. Acta, Vol. 40 (1995), p. 335

[13] B. Smitha, S. Sridhar and A.A. Khan, J. Membr. Sci.Vol. 259 (2005), p. 10

[14] M. Cappadonia, J.W. Erning, S.M.S. Niaki and U. Stimming, Solid State Ionics, Vol. 77(1995), p. 65

[15] K.D. Kreuer, Solid State Ionics, Vol. 97 (1997), p. 1

[16] K.D. Kreuer, J. Membrane Sci. Vol. 185 (2001), p. 29

[17] S. Dokmaisrijan and E. Spohr, J. Mol. Liq. Vol. 129 (2006), p. 92.

[18] S. Litster and G. McLean, J. Power Sources, Vol.130 (2004), p. 61

[19] P. Costamagna and S. Srinivasan, J. Power Sources, Vol. 102 (2001), p. 242.

[20] S. Basu, Recent Trends in Fuel Cell Science and Technology P47.

[21] P.L. Antonucci, A.S. Arico, P. Creti, E. Ramunni and V. Antonucci, Solid State Ionics, Vol. 125(1999), p. 431

[22] K.T.Adjemian, S.J. Lee, S. Srinivasan, J. Benziger and A.B. Bocarsly, J. Electrochem. Soc. Vol. 149(2002), p. A256

[23] H. Wang, B.A. Holmberg, Z.B. Wang, A. Mitra, J.M.Norbeck and Y.Yan, J. Mater. Chem., Vol. 12(2002), p. 834

[24] P. Costamagna, C. Yang, A.B. Bocarsly and S.Srinivasan, Electrochim. Acta, Vol.47 (2002), p. 1023

[25] C.Yang, P. Costamagna, S.Srinivasan, J. Benziger and A.B. Bocarsly, J. Power Sources, Vol.103 (2001), p. 1

[26] A.K.Sahu, S. Pitchumani, P.Sridhar, and A.K. Shukla, Bull. Mater. Sci., Vol.32 (2009), p. 285

[27] N. H. Jalani, K. Dunn and R. Datta, Electrochim. Acta, Vol.51 (2005), p. 553

[28] A. Saccà, I. Gatto, A. Carbone, R. Pedicini and E. Passalacqua, J. Power Sources, Vol. 163 (2006), p. 47

[29] Y. Zhai, H. Zhang, J. Hu and B.Yi, J. Membr. Sci., Vol.280 (2006), p. 148 
[30] A. Saccà, A. Carbone, E. Passalacqua, A. D.Epifanio, S. Licoccia, E. Traversa, E. Sala, F. Traini and R. Ornelas, J.Power Sources, Vol.152 (2005), p. 16

[31] Z-G. Shao, H. Xu, M. Li and I-M. Hsing, Solid State Ionics, Vol.177 (2006), p. 779

[32] J.Y. Yang, Y.L. Li, Y.Q. Huang, J.Y. Liang and P.K. Shen, J. Power Sources, Vol.177 (2008), p. 56

[33] V. Ramani, H R. Kunz and J.M. Fenton, J. Membr. Sci., Vol.232 (2004), p. 31

[34] F. Bauer and M. W-Porada, J. Power Sources, Vol.145 (2005), p. 101

[35] R. Jiang, H.R. Kunz and J.M. Fenton, Electrochim. Acta, Vol.51 (2006), p. 5596

[36] L-C. Chen, T.L. Yu, H-L. Lin and S-H. Yeh, J. Membrane Sci. Vol. (2007),

[37] Y-T. Kim, K-H.Kim, M-K. Song and H-W. Rhee, Curr. Appl. Phys., Vol.6 (2006) p. 612

[38] S.C. Byun, Y.J. Jeong, J.W. Park, S.D. Kim, H.Y. Ha and W.J. Kim, Solid State Ionics, Vol.177 (2006), p. 3233

[39] S-H. Kwak, T-H. Yang, C-S. Kim and K.H. Yoon, Electrochim. Acta, Vol.50 (2004), p. 653

[39a] S.H. Kwak, T.H. Yang, C.S. Kim, K.H. Yoon, Solid State Ionics, 160 (2003) 309

[40] Y-S. Park and Y. Yamazaki, Solid State Ionics, Vol.176 (2005), p. 1079

[41] L. Wang, B.L. Yi, H.M. Zhang and D.M. Xing, Electrochim. Acta, Vol.52 (2007), p. 5479

[42] Y.-Z. Fu and A. Manthiram, J. Electrochem. Soc., Vol.154 (2007), p. B8

[43] Y.H. Liu, B.L. Yi, Z.G. Shao, D.M. Xing and H.M. Zhang, Electrochem. Solid State Lett. Vol. 9 (2006), p. A356

[44] R. Kannan, B.A. Kakade and V.K.Pillai, Angew. Chem., Int. Ed. Vol. 47(2008), p. 2653

[45] J. Yang, P.K. Shen, J. Varcoe and Z. Wei, J. Power Sources, Vol.189 (2009), p. 1016

[46] X. Glipa and M. Hogarth, Department of Trade and Industry (UK) Homepage, 2001. Available from World Wide Web: http://www.dti.gov.uk/renewable/pdf/f0200189.pdf.

[47] Ion Power Homepage, Nafion ${ }^{\circledR}$ Material Safety Data Sheet (MSDS). Available from World Wide Web: http://ion-power.com/nafion/naf001.html 
[48] T. Kallio, K. Jokela, R. Serimaa, H. Ericson, G. Sundholm, P. Jacobsson and F. Sundholm, J. Appl. Electrochem., Vol.33 (2003), p. 505

[49] Tanja Kallio, Electrochemical and physicochemical characterization of radiation-grafted membranes for fuel cells, doctoral thesis, University of Helsinki, Department of Chemical Technology, Helsinki 2001, 15 p.

[50] S. Hietala, Characterization of Poly (vinylidene-graft-poly (styrene sulfonic acid)

Polymer Electrolyte Membrane, doctoral thesis, University of Helsinki, Department of Chemistry, Helsinki 1999, 41 p.

[51] H.-P. Brack and G.G. Scherer, Macromol. Symp. Vol.126 (1997), p. 25

[52] M.M. Nasef, H. Saidi, H.M Nor and M. Foo, J. Appl. Polym. Sci. Vol.76 (2000), p. 1

[53] N. Walsby, M. Paronen, J. Juhanoja and F. Sundholm, J. Appl. Polym. Sci. Vol. 81 (2001), p. 1572

[54] J. Li, A. Matsuura, T. Kakigi, T. Miura, A. Oshima and M. Washio, J. Power Sources, Vol.161 (2006), p. 99

[55] L. Gubler, S.A. Gürsel and G.G. Scherer, Fuel Cells, Vol.5 (2005), p. 317

[56] T. Navessin,M. Eikerling,Q. Wang,D. Song,Z. Lin,J. Horsfall,K.V. Lovell and S. Holdcroft, J. Electrochem. Soc .Vol.152 (2005), p. A796

[57] L. Gubler,H. Kuhn,T.J. Schmidt,G.G. Scherer,H.P. Brack and K. Simbeck, Fuel Cells Vol.4 (2004), p. 196

[58] Brack HP, Büchi FN, Huslage J, Scherer GG (1998) In: Gottesfeld S, Fuller TF (eds)

Proceedings of the 2 nd symposium on proton conducting membrane fuel cells II, proceedings vol 98-27. The Electrochemical Society, Boston, p 52

[59] T.Kallio, M.Lundstrom, G.Sundholm, N. Walsby and F. Sundholm, J. Appl. Electrochem. Vol. 32(2002), p. 11

[60] T.Kallio, K.Jokela,H. Ericson,R. Serimaa,G. Sundholm,P. Jacobsson and F.Sundholm, J. Appl. Electrochem. Vol.33 (2003), p. 505

[61] K.D.Kreuer, J. Membr. Sci., Vol.185 (2001), p. 29

[62] H.Tang and P.N. Pintauro, J Appl. Polym. Sci., Vol.79 (2001), p. 49

[63] M. Aoki, N. Asano, K. Miyatake, H. Uchida, M. Watanabe, J. Electrochem. Soc. Vol.153, (2006), p. A1154 
[64] M.Aoki, Y.Chikashige, K. Miyatake, H. Uchida, M. Watanabe, Electrochem. Commun.

Vol.8,(2006), p. 1412

[65] L. Jonissen,V. Gogel, J. Kerres and J. Garche, J. Power Sources, Vol.105 (2002), p. 267

[66] C. Genies, R. Mercier, B. Sillion, N. Cornet, G. Gebel and M. Pineri, Polymer, Vol.42 (2001), p. 359

[67] X.Guo, J. Fang, T. Watari, K. Tanaka, H. Kita and K.Okamoto, Macromolecules, Vol.35 (2002), p. 6707

[68] S. Besse, P. Capron and O.Diat, J. New Mater. Electrochem. System, Vol.5 (2002), p.109

[69] M. Kawahara, M. Rikukawa, K. Sanui and N. Ogata, Solid State Ionics, Vol.136 (2000), p. 1193

[70] J.M. Bae, I. Honma, M. Murata, T. Yamamoto, M. Rikukawa and N. Ogata, Solid State Ionics, Vol.147 (2002), p. 189

[71] H.R. Allcock, M.A. Hofmann and C.M. Ambler, J. Membr. Sci., Vol.201 (2002), p. 47

[72] M.A. Hofmann, C.M. Ambler and A.E. Maher, Macromolecules, Vol.35 (2002), p. 6490

[73] R. Carter, R. Wycisk, H. Yoo and P.N. Pintauro, Electrochem. Solid State Letters, Vol.5, (2002), p. A195

[74] Q. Li, R. He, J.O. Jensen and Bjerrum, Chem. Mater., Vol.15 (2003), p. 4896

[75] M.A. Hickner, H. Ghassemi, Y.S. Kim, B.R. Einsla and J.E. McGrath, Chem. Rev. Vol.104 (2004), p. 4587

[76] R.Souzy and B. Ameduri, Prog. Polymer Sci., Vol.30 (2005), p. 644

[77] C.A.Edmonson, J.J Fontanella, S.H. Chung, S.G. Greenbaum and G.E.Wnek, Electrochim. Acta, Vol. 46(2001) p.1623

[78] B.M. Sheikh-Ali and G.E. Wnek, US Patent 6,100,616 (2000)

[79] V.I. Basura, C. Chuy, P.D. Beattie and S. Holdcroft, J. Electroanal.Chem. Vol. 501(2001), p. 77

[80] Ehrenberg SG, Serpico JM, Sheikh-Ali BM, Tangredi TN, Zador E, Wnek GE (1997) In: Savadogo O, Roberge PR, Valeriu A (eds) New materials for fuel cell and modern battery systems II: 
proceedings of the second international symposium on new materials for fuel cell and modern battery systems. l'Ecole Polytechnique de Montreal,

Montreal, p 828

[81] S.Besse and P. Capron. Diat,G. Gebel, F.Jousse, et al. J. New Mater. Electrochem.Syst. Vol.5 (2002), p.109

[82] N.Cornet, O.Diat, G. Gebel, F. Jousse, D. Marsacq, R. Mercier, M. Pineri, J. New Mater. Electrochem. Syst. Vol.3 (2000), p.33

[83] J.A. Blazquez, J.J. Iruin, S. Eceolaza, C. Marestin, R. Mercier, D.Mecerreyes, O.Miguel, A.Vela and R. Marcilla, J. Power Sources, Vol. 151(2005), p. 63

[84] S.Besse, P.Capron, O. Diat, G.Gebel, F.Jousse, D. Marsacq, M.Pinéri, C.Marestin and R.Mercier, J. New Mater. Electrochem. Syst. Vol.5 (2002), p.109

[85] F.Lufrano, G. Squadrito, A. Patti and E. Passalacqua, J. Appl. Polym. Sci. Vol.77 (2000), p.1250

[86] B. Baradie, C. Poinsignon, J.Y. Sanchez, Y. Piffard, G. Vitter, N Bestaoui, D Foscallo, A Denoyelle, D Delabouglise and M Vaujany, J. Power Sources, 74 (1998), p.8

[87] W.L.Harrison, M.A. Hickner, Y.S. Kim and J.E. McGrath, Fuel Cells, 5(2005), p.201

[88] T.Soczka-Guth, J. Baurmeister, G. Frank and R. Knauf, WO Patent 29763(1999)

[89] B.Bauer, D.J. Jones. Rozi ere,L. Tchicaya,G. Alberti, et al. 2000. J. New Mater. Electrochem. Syst. 3:93-98

[90] T.G.Soczka, J.Baurmeister, G. Frank and R. Knauf, Int. Patent 29763 (1999)

[91] T. Kobayashi, M. Rikukawa, K. Sanui and N.Ogata, Solid State Ionics, Vol.106 (1998), p. 219

[92] E. Fontananova, F. Trottac, J. C. Jansen and E. Drioli, J. Membr. Sci. Vol. 348 (2010), p. 326

[93] E.Chalkova, X.Y.Zhou, C.A Ambler, M.A.Hoffmann, I.A.Weston, H.R. Allcock, and S.N. Lvov, Electrochem. Solid-State Lett. Vol.5 (2002), p.A221

[94] J.A.Kerres. J. Membr. Sci. Vol.185 (2001), p.3

[95] J.A.Kerres and A. Ullrich, Separation Purification Technol. Vol.22 (2001), p.1

[96] J. Kerres, A. Ullrich, F. Meier and T. Haring, Solid State Ionics, Vol.125 (1999), p. 243

[97] J. A. Kerres, J. Membr Sci, Vol.185 (2001), p. 3 
[98] M. Walker, K.M.Baumgartner, M. Kaiser, J. Kerres, A. Ullrich and E.J.Rauchle, Appl. Polym. Sci., Vol.74 (1999), p. 67

[99] X.Ren, M.S. Wilson and S.Gottesfeld, J. Electrochem. Soc, Vol.143 (1996), p. L12

[100] R. Bashyam and P. Zelenay, Nature, Vol.443 (2006), p. 163

[101] T. R. Ralph and M. P. Hogarth, Platinum Met. Rev. Vol.46 (2002), (1), S14

[102] E.I.Santiago, M.S.Batista, E.M. Assaf and E.A. Ticianelli, J. Electrochem. Soc. Vol. 151(2004), A944

[103] L. G. S. Pereira, V. A. Paganin and E. A. Ticianelli, Electrochim. Acta, Vol.54 (2009), p.1992

[104] P.A. Adcock, S.V. Pacheco, K.M. Norman and F.A. Uribe, J. Electrochem. Soc. Vol. 152 (2005), p. A459

[105] F.A. Uribe, J.A. Valerio, F.H. Garzon and T.A. Zawodzinski, Electrochem. SolidState Lett. Vol.7 (2004), p. A376

[106] W.F. Lin, T. Iwasita and W. Vielstich, J. Phys. Chem. B, Vol.103 (1999) p. 3250

[107] S. J. Lee, S. Mukerjee, E. A. Ticianelli and J. McBreen, Electrochim. Acta, Vol.44 (1999), p. 3283

[108] M. Carmo, V.A. Paganin, J.M. Rosolenand and E.R. Gonzalez, J. Power Sources, Vol.142 (2005), p. 169

[109] H. Gasteiger, N. Markovic and P.N. Ross, J. Phys. Chem., Vol.99 (1995) p. 8290

[110] T. J. Schmidt, M. Noeske, H. A. Gasteiger and R. J. Behm, J. Electrochem. Soc., Vol.145 (3) (1998), p. 925

[111] E.M. Crabb, R. Marshall and T. David, J. Electrochem. Soc. Vol.147 (2000), p. 4440

[112] L.G.S. Pereira V. A. Paganin and E. A. Ticianelli, Electrochim. Acta, Vol.54 (2009), p. 1992

[113] P Z. Liu, J.E. Hu, Q. Wang, K.J. Gaskell, A.I. Frenkel and B.W. Eichhorn, J. Amer.Chem. Soc. Vol.131 (2009), p. 6924

[114] H. Yano, C. Ono, H. Shiroishi and T. Okada, Electrochem. Solid-State Lett. Vol.11 (220), p. B96

[115] H. Yano, C. Ono, H. Shiroishi and T. Okada, Chem. Commun. (2005), p. 1212 
[116] M. Götz and H. Wendt, Electrochim. Acta, Vol.43 (1998), p. 3637

[117] F. Maillard, E. Peyrelade, Y. Soldo-Olivier, M. Chatenet, E. Chanet and R. Faure, Electrochim. Acta, Vol.52 (2007), p. 1958

[118] A. C. Garcia, V. A. Paganin and E. A. Ticianelli, Electrochim. Acta, Vol.53 (2008), p. 4309

[119] M.Watanabe and S. Motoo, J. Electroanal. Chem. Vol. 60 (1975), p. 267

[120] E. Christoffersen, P. Liu, A. Ruban, H.L. Skriver and J.K. Norskov, J. Catal. Vol.199 (2001), p. 123

[121] P. Liu, J.K. Logadottir and J.K. Norskov, Electrochim. Acta, Vol.48 (2003), p. 3731

[122] H.A. Gasteiger, M.N. Markovic and P.N. Ross, J. Phys. Chem. B, Vol.99 (1995) 8290

[123] J. Kaiser, L. Colmenares, Z. Jusys, R. Mörtel, G. Köhl and R.J. Behm, Fuel Cells, Vol.6 (2006), p.190

[124] M. Mazurek, N. Benker, C. Roth and H. Fuess, Fuel Cells, Vol.6 (2006), p. 208

[125] F. Maillard, F. Gloaguen, F. Hahn and J.M. Léger, Fuel Cells, Vol.2 (2002), p. 143

[126] H. Igarashi, T. Fujino, Y. Zhu, H. Uchida and M.Watanabe, Phys. Chem. Chem. Phys. Vol.3 (2001), p. 306

[127] R. B. Levy and M. Boudart, Science, Vol.181 (1973), p. 54

[128] J. J. Huang and J. W. Rabalais, Chem. Phys. Lett. Vol.34, (1975), p. 337

[129] D. J. Ham, Y. K. Kim, S.H. Han and J. S. Lee, Catalysis Today, Vol.132 (2008) p. 117

[130] F. Maillard, E. Peyrelade, Y. Soldo-Olivier, M. Chatenet, E. Chainet and R. Faure, Electrochim. Acta, Vol.52 (2007), p. 1958

[131] K. Y. Chen, Z. Sun and A. C. C. Tseung, Electrochem. Solid-State Lett. Vol. 3, (2000), p. 10

[132] R. Venkataraman, H. R. Kunz and J. M. Fenton, J. Electrochem. Soc. Vol.150, (2003), p. A278

[133] Y. Liang, H. Zhang, H. Zhong, X. Zhu , Z. Tian, D. Xu and Y. Baolian, J. Catalysis, Vol.238 (2006), p. 468

[134] B. Moreno, J.R. Jurado and E. Chinarro, Catal. Commun. 11 (2009) p. 123 
[135] L. Ma, H.M. Zhang, Y.M. Liang, D.Y. Xu, W. Ye, J.L. Zhang and B.L. Yi, Catal. Commun. Vol.8 (2007), p. 921

[136] D. C. Papageorgopoulos, M. Keijzer and F. A. de Bruijn, Electrochim. Acta, Vol.48 (2002), p. 197

[137] T.J. Schmidt, Z. Jusys, H.A. Gasteiger, R.J. Behm, U. Endruschat and H. Boennemann, J. Electroanal. Chem. Vol.501 (2001), p. 132

[138] M. Nagai, M. Yoshida, H and Tominaga, Electrochim. Acta, Vol.57 (2007), p. 5430

[139] S. Izhar and M. Nagai, J. Power Sources, Vol.182 (2008), p. 52

[140] T. R. Ralph and M. P. Hogarth, Platinum Metals Rev. Vol.46 (2002), p. 117

[141] R.C.Urian, A.F. Gulla and S. Mukerjee, J. Electroanal. Chem. Vol.554 (2003), p. 307

[142] J-H. Wee and K-Y. Lee, J. Power Sources, Vol.157 (2006), p. 128

[143] J.K. Norskov, J. Rossmeisl, A. Logadottir, L. Lindqvist, J.R. Kitchin, T. Bligaard and H. Jonsson, J. Phys. Chem. B Vol. 108 (2004), p. 17886

[144] J. Greeley, I. E. L. Stephens, A. S. Bondarenk, T. P. Johansson, H. A. Hansen1, T. F. Jaramill,J. Rossmeis11, I. Chorkendorff and J. K. Nørskov, Nature Chemistry, Vol. 1 (2009), p. 552

[145] H.A.Gasteiger, S.S. Kocha, B. Somappli, and F.T.Wagner, Appl. Catal. B-Environ. Vol.56, (2005), p.9

[146] V. R. Stamenkovic, B.Fowler, B. S. Mun, G.Wang, P. N. Ross,C.A. Lucas and N.M. Markovic, Science, Vol.315, (2007), p. 493

[147] S.Koh and P. Strasser, J. Amer.Chem. Soc. Vol. 129, (2007), p. 12624

[148] S. Chen, W. Sheng, N. Yabuuchi, P. J. Ferreira, L. F. Allard and Y. S.-Horn J. Phys.Chem. C, Vol.113, (2009), p. 1109

[149] W. Wakisaka, H. Suzuki, S. Mitsui, H. Uchida, and M. Watanabe, J. Phys. Chem. C, Vol.112, (2008), p. 2750

[150] V. Stamenkovic,B.S. Mun,K.J.J. Mayrhofer, P.N. Ross, N.M. Markovic, J.Rossmeisl, J. Greeley and J.K. Nørskov, Angew. Chem. Int. Ed. Vol.45, (2006), p. 2897

[151] N.M.Markovic, P.N. Ross, U.A.Paulus, A. Wokaun, G.G. Scherer, T.J. Schmidt, and V. Stamenkovic, Electrochim. Acta, Vol.47, (2002), p. 3787 
[152] U.A. Paulus, A. Wokaun, G.G. Scherer, T.J. Schmidt, V. Stamenkovi,

V. Radmilovic, N.M. Markovic and P.N. Ross. J. Phys. Chem. B, Vol. 106, (2002),

p. 4181

[153] K.J.J.Mayrhofer, V. Juhart, K. Hartl, M. Hanzlik, and M. Arenz, Angew. Chem. Int. Ed. Vol.48, (2009), p. 3529

[154] S. Koh, J. Leisch, M.F.Toney and P. Strasser, J. Phys. Chem. C, Vol.111, (2007), p. 3744

[155] S.Koh, M.F.Toney and P.Strasser, Electrochim. Acta Vol.52, (2007), p. 2765

[156] T.-Y.Jeon, S.J. Yoo, Y.-H. Cho, K.-S. Lee, S.H Kang and Y.-E.Sung, J. Phys. Chem. C, Vol.113 (45), p. 19732

[157] V. Jalan and E. J. J. Taylor, J. Electrochem. Soc., Vol.130 (1983), p. 2299

[158] M. T. Paffett, J. G. Berry and S. Gottesfeld, J. Electrochem. Soc., Vol.135 (1988), p. 1431

[159] B. C. Beard and P. N. Ross, J. Electrochem. Soc., Vol.137 (1990), p. 3368

[160] T. Toda, H. Igarashi, H. Uchida and M. Watanabe, J. Electrochem. Soc., Vol.146 (1999), p. 3750

[161] A. Gamez, D. Richard, P. Gallezot, F. Gloaguen, R. Faure and R. Durand, Electrochim. Acta, Vol.41 (1996), p. 307

[162] B. L. Gratiet, H. Remita, G. Picq and M. O. Delcourt, J. Catal., Vol.164 (1996), p. 36

[163] T F. Maillard, M. Martin, F. Gloaguen and J.-M. Leger, Electrochim. Acta, Vol. 47(2002), p. 3431.

[164] R. Srivastava, P. Mani, N. Hahn and P. Strasser, Angew. Chem. Int. Ed. Vol. 46 (2007), p.8988

[165] B. Lim, M. Jiang, P.H.C. Camargo, E.C. Cho, J. Tao, X. Lu, Y. Zhu and Y. Xia, Science, Vol. 324 (2009), p. 1302

[166] J. Zhang, H. Yang, J. Fang and S.Zou, Nano Lett.Vol.10 (2010), p. 638

[167] W. Wang, R. Wang, S. Ji , H. Feng, H. Wanga and Z. Lei, J. Power Sources Vol.195 (2010), p. 3498

[168] S. H. Joo, S. J. Choi, I. Oh, J. Kwak, Z. Liu, O. Terassaki and R. Ryoo, Nature, Vol.412 (2001), p.169 
[169] L. Xiong, A. M. Kannan and A. Manthiram, Electrochem. Commun. Vol.4 (2002), p. 898.

[170] G.Gupta, D. A. Slanac, P. Kumar, J. D. Wiggins-Camacho,X. Wang,.S. Swinnea, Karren L. More, S. Dai, K. J. Stevenson and K.P. Johnston, Chem. Mater. Vol.21 (2009), p. 4515

[171] J. Wu, J. Zhang, Z. Peng, S. Yang, F. T. Wagner and H. Yang Truncated Octahedral Pt 3 Ni ORR Electrocatalysts, J. Am. Chem. Soc. (2010) (in press)

[172] Z. Chen, M. Waje, W. Li and Y. Yan, Angew. Chem. Int. Ed. Vol.46 (2007), p. 4060

[173] W.Li, Z.Chen, L. Xu and Y. Yan, J. Power Sources, Vol.195 (2010), p. 2534

[174] S. Jiang, Y. Ma, G. Jian, H. Tao,X. Wang, Y. Fan, Y. Lu, Z. Hu, and Y. Chen, Adv. Mater. Vol.21 (2009), p.4953

[175] C.-J. Zhong, J. Luo, B. Fang, B. N. Wanjala,P. N. Njoki, R. Loukrakpam and J. Yin, Nanotechnology Vol. 21 (2010), p. 062001

[176] J.J. Salvador-Pascual, V. Collins-Martínez, A. López-Ortíz and O. Solorza-Feria, J. Power Sources, Vol.195 (2010), p. 3374

[177] Y. Ma, H. Zhang, H. Zhong, T. Xu, H. Jin, and X. Genga, Catal. Commun. Vol.11 (2010), p. 434

[178] J. K. Norskov, J. Rossmeisl, A. Logadottir, L. Lindqvist,J. R. Kitchin, T. Bligaard and H. Jonsson, J. Phys. Chem. B, Vol. 108(2004), p. 17886

[179] O. Savadogo, K. Lee, K. Oishi, S. Mitsushima, N. Kamiya and K.-I. Ota, Electrochem. Commun. Vol.6 (2004), p. 105

[180] O. Savadogo, K. Lee, S. Mitsushima, N. Kamiya and K.-I. Ota, J. New Mat. Electrochem. Syst., Vol. 7 (2004), p. 77

[181] H. Liu and A. Manthiram, Electrochem. Commun. Vol.10 (2004), p. 740

[182] J. L. Fernandez, V. Raghuveer, A. Manthiram and A. J. Bard, J. Am. Chem. Soc., Vol.127 (2005), p. 13100

[183] V. Raghuveer, P. J. Ferreira and A. Manthiram, Electrochem. Commun. Vol.8 (2006), p. 807

[184] H. Liu and A. Manthiram, Energy Environ. Sci., Vol.2 (2009), p. 124

[185] E. Antolini, Energy Environ. Sci., Vol.2 (2009), p. 915 
[186] M. Nie, P.K. Shen and Z. Wei, J. Power Sources, Vol.167 (2007), p. 69

[187] J. Zhao, A. Sarkar and A. Manthiram, Electrochim. Acta, Vol.55 (2010), p. 1756

[188] A. Sarkar, A. V. Murugan and A. Manthiram, J. Mater. Chem., Vol.19 (2009), p. 159

[189] A. Sarkar, A. Vadivel Murugan, and A. Manthiram, J. Phys. Chem. C, Vol.112 (2008), p. 12037

[190] Ch. Venkateswara Rao, B. Viswanathan, Electrochim. Acta, Vol.55 (2010), p. 3002

[191] R. Wang, S. Liao, Z. Fu and S. Ji, Electrochem. Commun. Vol.10 (2008), p. 52

[192] V. Raghuveer, A. Manthiram and A.J. Bard, J. Phys. Chem. B 109 (48), (2005) p. 22909

[193] W. Li and P. Haldar, Electrochem. Commun. Vol. 11 (2009), p. 1195

[194] S. Song, Y. Wang, P. Tsiakaras and P. K. Shen, Appl. Catal. B-Environ. Vol. 78 (2008), p. 381

[195] Z. Zhang, X.Wang, Z. Cui, C.Liu, T. Lu and W. Xing, J. Power Sources Vol. 185 (2008), p. 941

[196] Y. Fu, Z.D.Wei, S.G. Chen, L. Li, Y.C. Feng, Y.Q.Wang, X.L. Ma, M.J. Liao,

P.K. Shen and S.P. Jiang, J. Power Sources Vol.189 (2009), p. 982

[197] J.M. Macak, F. Schmidt-Stein and P. Schmuki, Electrochem. Commun. 9 (2007) 1783

[198] N. Alexeyeva and K. Tammeveski, Analytica Chim. acta Vol.618 (2008), p. 140

[199] D. Wang, S. Lu and S. P. Jiang, Chem. Commun. Vol.46 (2010), p. 2058

[200] W. Wang, D. Zheng, C. Dua, Z. Zou, X. Zhang, B. Xia, H. Yang and D. L. Akins J. Power Sources, Vol.167 (2007) 243

[201] S. Tominaka, T. Momma and T. Osaka, Electrochim. Acta Vol.58 (2008), p. 4679

[202] S. Tominaka, Y. Nakamura and T. Osaka, J. Power Sources Vol.195 (2010) p. 1054

[203] S. Tominaka, Y. Nakamura and T. Osaka, J. Power Sources Vol.195 (2010) p. 1054

[204] M.-H. Shao, K. Sasaki and R. R. Adzic, J. Am. Chem. Soc., Vol.128(2006), p. 3526

[205] C. Xu, Y. Zhang, L. Wang,L. Xu, X. Bian, H. Ma,and Yi Ding, Chem. Mater. Vol.21 (2009), p. 3110

[206] G. Ramos-Sanchez and O. Solorza-Feria, Int. J. Hydrogen Energy, Vol. (2010), in press 
[207] G. Ramos-Sanchez and O. Solorza-Feria, Int. J. Hydrogen Energy, Vol.33 (2008), p.3596

[208] C.-L. Lee, Y.-C. Huang, L.-C. Kuo,J.-C. Oung and F.-C.Wu, Nanotechnology, Vol.17 (2006), p. 2390

[209] M. Lefevre, E. Proietti, F. Jaouen and J.P. Dodelet, Science, Vol.324 (2009), p.71

[210] N. P.Subramanian, S. P. Kumaraguru, H. Colon-Mercado,H. Kimc, B. N. Popov, T.Black and D.A. Chen, J. Power Sources Vol. 157(2006), p.56

[211] N. Alonso-Vante and H. Tributsch, Nature, Vol. 323(1986), p.431

[212] L.Zhang, J. Zhang, D.P.Wilkinson and H. Wang, J. Power Sources, Vol.156 (2006), p.171

[213] RuxSy, [196] R.W. Reeve, P.A. Christensen, A. Hamnett, S.A. Haydock and S.C. Roy, J. Electrochem. Soc. Vol.145 (1998), p.3463 (check this reference)

[214] S. Duron, R.Rivera-Noriega,M.A.Leyva,P. Nkeng,G. Poillerat and O. Solorza-Feria, J. Solid State Electrochem. Vol.4 (2000), p.70

[215] D. Leveratto, A. Racz, E. R. Savinova and U. Stimming, Fuel Cells, Vol.6 (2000), p.203

[216] N. Alonso-Vante, I.V. Malakhov, S.G. Nikitenko, E.R. Savinova, D.I.

Kochubey, Electrochim. Acta, Vol.47 (2002), p.3807

[217] K.Lee, L.Zhang and J. Zhang, Electrochem, Commun. Vol.9 (2007), p.1704

[218] L.Liu, J.W.Lee and B.N. Popov, J. Power Sources, Vol. 162 (2006), p.1099

[219] L.Liu, H. Kim, J.W.Lee and B.N.Popov, J. Electrochem. Soc. Vol.154 (2007), p. A123

[220] Y. Feng and N. Alonso-Vante, phys. stat. sol. Vol. 245 (2008), p. 1792

[221] J-W. Lee and B. N. Popov, J. Solid State Electrochem, Vol.11 (2007), p. 1355

[222] R. Jasinski, Nature, Vol.201 (1964), p. 1212

[223] C.W.B Bezerra, L.Zhang,H. Liu,K. Lee,A.L.B. Marques,E.P. Marques, H. Wang and J. Zhang, J Power Sources, Vol.173(2007), p.891

[224] F.Jaouen, S. Marcotte, J.P. Dodelet and G. Lindbergh, J. Phys. Chem. B, Vol. 107(2003), p. 1376.

[225] C. W.Bezerra, L. Zhang, K. Lee, H. Liu, A.L.B. Marques, E.P.Marques, H. Wang and J. Zhang, Electrochim. Acta, Vol.53 (2008), p.4937 
[226] F.Jaouen, S. Marcotte, J.P. Dodelet and G.Lindbergh, J. Phys. Chem. B, Vol.107 (2003), p.1376

[227] V. Nallathambi, J.W. Lee, S.P. Kumaraguru, G. Wu and B.N. Popov, J. Power Sources, Vol.183 (2008) p.34

[228] X. Yuan, X. Zeng, H-J. Zhang, Z-F. Ma and C-Y, Wang, J. Amer. Chem. Soc. Vol.132 (2010) p. 1754

[229] A.L. Reddy, N. Rajalakshmi and S. Ramaprabhu, Carbon, Vol.46 (2008), pp. 2

[230] T. Kudo, H. Obayashi and M.Yoshida, J. Electrochem. Soc. Vol.124 (1977), p.321

[231] M.Hayashi, T. Hyodo, N. Miura and N. Yamazoe, Electrochemistry, Vol.68 (2000), p.112

[232] T.Hyodo, M. Hayashi, N. Miura and N. Yamazoe, J. Electrochem. Soc. Vol.143 (1996), p.L266

[233] S. Imaizumi, K. Shimanoe, Y.Teraoka and N. Yamazoe, Electrochem. Solid-State Lett. Vol.8 (2005), p.A270

[234] M. El Baydi, G. Poillerat, J.L. Rehspringer, J.L. Gautier, J.F. Koenig and P.J.A. Chartier, J. Solid State Chem., Vol.109 (1994), p.281

[235] J.O.M. Bockris and T. Otagawa, J. Electrochem. Soc. Vol.131 (1984), p.290

[236] A. Smirnova, X. Dong, H. Hara, A. Vasiliev and N. Sammes, Int. J. Hydrogen Energy, Vol.30 (2005), p. 149

[237] J.C. Ndamanisha, X. Bo and L. Guo, Analyst, Vol.135 (3), (2010), p. 621

[238] X. Wang, W.Z. Li, Z.W. Chen, M. Waje and Y.S. Yan, J. Power Sources, Vol.158 (2006), p. 154

[239] Y.Zhou, T. Holme, J. Berry, T.R. Ohno, D. Ginley and R. OHayre, J. Phys. Chem. C, Vol.114 (2010), p. 506

[240] X. Lia, S. Parka and B.N. Popov, J. Power Sources, Vol.195 (2010), p. 445

[241] K.P. Gong, F. Du, Z.H. Xia, M. Durstock and L.M. Dai, Science, Vol.323 (2009), p. 760

[242] Y. Shao, J. Liu, Y. Wang and Y. Lin, J. Mater. Chem., Vol.19 (2009), p. 46

[243] K. Kinoshita, Carbon: Electrochemical and Physicochemical Properties, Wiley, New York, 1988, p. 319 
[244] K. Kinoshita and J.A.S. Bett, Carbon, Vol.11 (1973), p. 403

[245] K.-S. Lee, I.-S. Park, Y.-H. Cho, D.-S. Jung, N. Jung, H.-Y. Park and Y.-E. Sung, J. Catal. Vol.258 (2008), p. 143

[246] T. Ioroi, Z. Siroma, N. Fujiwara, S. Yamazaki and K. Yasuda, Electrochem. Commun. Vol.7 (2005), p. 183

[247] H. Chhina, S. Campbell and O. Kesler, J. Power Sources, Vol. 161 (2006), p. 89

[248] Z. Qi and P. G. Pickup, Chem. Commun., (1998), p. 2299

[249] Z.H. Zhang, X.G. Wang, Z.M. Cui, C.P. Liu, T.H. Lu and W. Xing, J. Power Sources, Vol.185 (2008), p.941

[250] J. Parrondo, F. Mijangos and B. Rambabu, J. Power Sources, Vol.195 (2010), p.3977

[251] B. Seger, A. Kongkanand, K. Vinodgopal and P. V. Kamat, J. Electroanal.Chem. Vol. 621(2008), p.198

[252] C. Du, M. Chen, X. Cao, G. Yin and P. Shi, Electrochem. Commun. Vol.11 (2009), p. 496

[253] Y. Suzuki, A. Ishihara, S. Mitsushima, N. Kamiya and K. Ota, Electrochem. Solid-State Lett. Vol. 10, (2007) p. B105

[254] T. Ioroi, Z. Siroma, N. Fujiwara, S. Yamazaki and K. Yasuda, Electrochem. Commun. Vol.7 (2005) p. 183

[255]R. Elezović, B.M. Babić, Lj. Gajić-Krstajić, V. Radmilović, N.V. Krstajić and L.J. Vračar, J. Power Sources, Vol.195 (2010), p. 3961

[256] R. Kou, Y. Shao, D. Wang, M.H. Engelhard, J.H. Kwak, J. Wang, V. Viswanathan, C. Wang, Y. Lin, Y. Wang, I.A. Aksay and J. Liu, Electrochem. Commun. 11 (2009), p. 954.

[257] A.Bauer, K. Lee, C. Song, Y. Xie, J. Zhang and R. Hui, J. Power Sources, Vol.195 (2010), p. 3105

[258] X. Liu, J. Chena,, G. Liu, L. Zhang, H. Zhang and B. Yia, J. Power Sources, Vol.195 (2010), p. 4098

[259] M. D. Gasda, G. A. Eisman and D. Gall, J. Electrochem. Soc., Vol. 157 (2010), p. B71

[260] H. Scholl, B. Hofman and A. Rauscher, Electrochim. Acta, Vol.37 (1992), p. 447 
[261] L.G.R.A. Santos, K.S. Freitas and E.A. Ticianelli, J. Solid State Electrochem. Vol.11 (2007), p.1541

[262] A. Honji, T. Marl and Y. Hishinuma, J. Electrochem. Soc. Vol.135 (1988), p. 917.

[263] V. Jalan and D.G. Frost, US Patent 4795684 (1989).

[264] B. Avasarala, T. Murray, W.Z. Li and P. Haldar, J. Mater. Chem. Vol.19 (2009), p.1803

[265] S. Yin, S. Mua, H. Lv Niancai Cheng, M. Pan and Z. Fu, Applied Catalysis B: Environ, Vol.93 (2010), p.233

[266] A.H. Chen, K. Kamata and M. Nakagama, J. Phys. Chem. B, Vol.109 (2005), p. 18283

[267] S-Y. Huang, P. Ganesan and B.N. Popov, Applied Catalysis B: Environ, Vol. 93 (2009), p. 75

[268] C.Coutanceau, M.J.Croissant, T. Napporn and C.Lamy, Electrochim. Acta, Vol.46 (2000), p. 579

[269] S.Mokrane, L.Makhloufi, N. Alonso-Vante, J. Solid State Electrochem. Vol.12 (2008), p.569

[270] P. Gajendran, S. Vijayanand and R. Saraswathi, J.Electroanal. Chem. Vol.601 (2007), p. 132

[271] M. Gao, F.Yang, G. Zhang, L. Liu and X.Wang, Electrochim. Acta, Vol.54

(2009), p.2224

[272] C. Jiang and X. Lin, J. Appl. Electrochem., Vol.38 (2008), p. 1659

[273] J. Chojnack, E. Morales and J. L. Acosta, J. New Mater. Electrochem. System, Vol.12 (2009), p. 123

[274] M. Hana, J.H. Xua, S.H. Chan and S.P. Jiang, Electrochim. Acta, Vol.53 (2008), p.5361

[275] L. Cindrella, A.M. Kannan, J.F. Lin, K. Saminathan, Y. Ho, C.W. Lin and J. Wertz, J. Power Sources, Vol.194 (2009), p. 146

[276] V. Mehta and J. S. Cooper, J. Power Sources, Vol.114 (2003), p. 32

[277] M.Mamlouk,Investigation of High Temperature Polymer Fuel Cells, Phd thesis, Newcastle university, School of chemical engineering and advanced materials, 2008

[278] A.S. Arico, A. Stassi, E. Modica, R. Ornelas, I. Gatto, E. Passalacqua and V. Antonucci, J. Power Sources, Vol. 178 (2008),p. 525 
[279] N. N. Krishnan, H.-J. Lee, H-J Kim, J-Y. Kim, I.Hwang, J. H. Jang, E.A. Cho, S.-K. Kim, D. Henkensmeier, S.-A. Hong, T.-H. Lim, European Polymer Journal (in press)

[280] M.VWilliams, E.Begg, L. Bonville, H.R. Kunz, J.M.Fenton, J. Electrochem Soc. Vol. 151 (2004), p. A1173 